\title{
ESTIMATIVA DO SALDO DO GOVERNO NA COMERCIALIZACÃO DE ÁLCOOL CARBURANTE
}

\author{
CAETANO BRUGNARO
}

Engenheiro Agrônomo

Orientador: PROF.DR.JOSÉ FERREIRA DE NORONHA

Dissertação apresentada à Escola Superior de Agricultura "Luiz de Queiroz", da Universidade de São Paulo, para obtenção do título de Mestre em Agronomia, Área de Concentração: Economia Agrária.

\author{
P I R A C I C A B A \\ Estado de São Paulo - Brasil \\ Fevereiro - 1992
}


Ficha catalográfica preparada pela Seção de Livros da Divisão de Biblioteca e Documentação - PCAP/USP

Brugnaro, Caetano

B89le Estimativa do saldo do governo na comercialização de álcool carburante. Piracicaba, 1992.

100p.

Diss.(Mestre) - ESALQ

Bibliografia.

1. Alcoo1 motor - Preço - Modelo matemático 2. Combustí ve1 - Preço - Modelo matemático 3. Modelo matemático I. Es cola Superior de Agricultura Luiz de Queiroz, Piracicaba

CDD $\quad 338.47662669$ 


\section{ESTIMATIVA DO SALDO DO GOVERNO NA COMERCIALIZACÃO DE ÁLCOOL CARBURANTE}

Caetano Brugnaro

Aprovada em 10/04/1992.

Comissão Julgadora:

Prof.Dr.Carlos José Caetano Bacha ESALQ/USP

Prof.Dr.José Ferreira de Noronha ESALQ/USP

Profa Dra Maria Aparecida Anselmo Tarsitano FEIS/UNESP

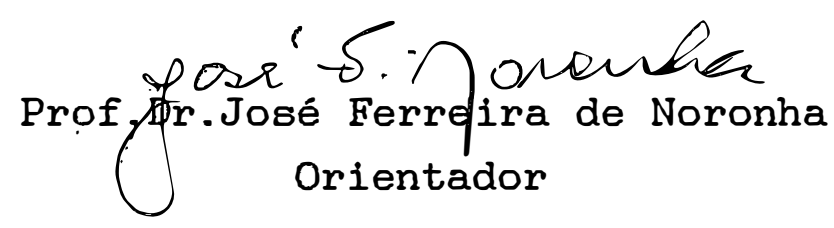


iii.

Aos meus filhos

Camila e Paulo DEDICO 
iv.

AGRADECIMENTOS

Prof.Dr.Josê Ferreira de Noronha - Orientador -

Gabriel Rabelo de Oliveira Neto Jose de Moraes Falcão 
SUMARIO

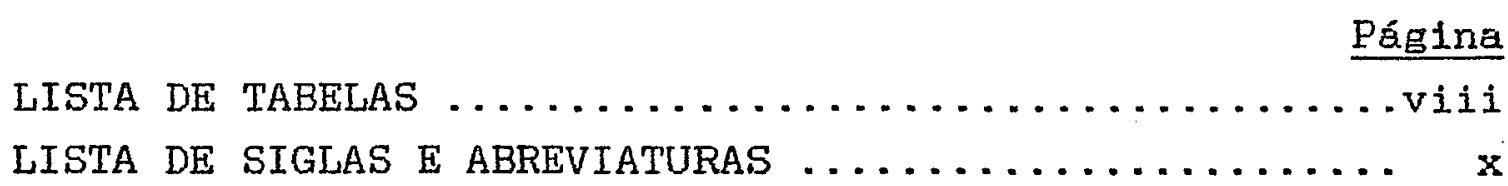

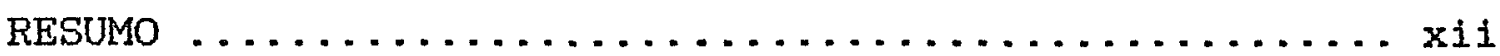

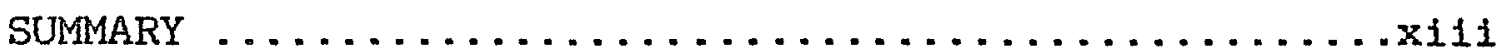

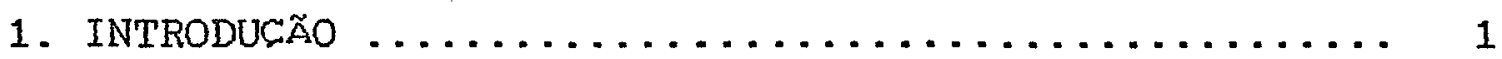

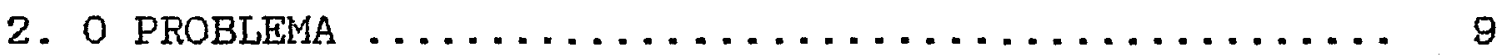

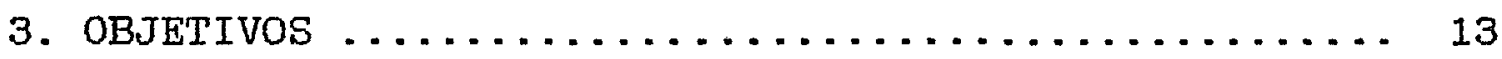

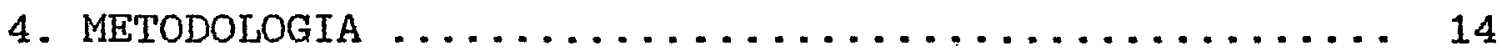

4.1. Estrutura de preços dos derivados de petróleo. 14

4.2. Estrutura de preços do álcool carburante ..... 17

4.2.1. Anidro ..................... 19

4.2.2. Hidratado ................. 19

4.3. Tributação na fase agrícola ............. 20

4.4. Empréstimo compulsório ................ 21

4.5. Modelos de análise .................. 21

4.6. Procedimentos específicos .............. 32

4.6.1. Período de análise $\ldots \ldots \ldots \ldots \ldots \ldots \ldots . \ldots 32$

4.6.2. Dados necessários ................ 32

4.6.3. Tributos sobre a matéria-prima ....... 33

4.6.4. Outros tributos ................ 36

4.6.5. Subsidios de equalização de custos .... 36

4.6.6. Custos de transporte e armazenagem ..... 37

4.7. Cenários ......................... 38

4.7.1. Produto Interno Bruto ............ 39

4.7.2. Precos médios dos combustíveis ao consumidor ................... 40

4.7.3. Precos relativos otto/diesel ........ 41

4.7.4. Coeficientes de transformação em tEP ... 43 
vi.

Página

4.7.5. Taxa de mistura de álcool anidro à gasolina ........................ 44

4.7.6. Precos da gasolina ao consumidor final ....................... 46

4.7.7. Relações entre elementos de receita e elementos de despesa do Governo e o preco da gasolina ............... 48

4.7.8. Projeções da frota e do consumo medio de veículos a álcool ............ 49

4.7.9. Projecões dos custos de transporte e armazenagem do álcool carburante ..... 50

5. RESULTADOS E DISCUSSÃO ....................... 51

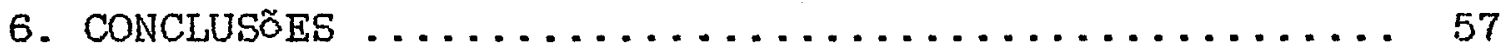

REFERÊNCIAS BIBLIOGRÁFICAS ................ 63

APÊNDICE 1. Exemplo de estrutura de pregos do álcool carburante no nível de produção ..... 66

APÊNDICE 2. Preços oficiais da cana-de-acúcar. Brasil, 1980-80 ................. 67

APÊNDICE 3. Estrutura de precos do élcool anidro carburante no nivel de produção. Brasil, 1980-90 ..................... 70

APÊNDICE 4. Estrutura de preços do álcool hidratado carburante no nivel de produção. Brasil, 1980-90 ................... 73

APÊNDICE 5. Consumo mensal aparente de álcool anidro para fine carburantes. Centro-

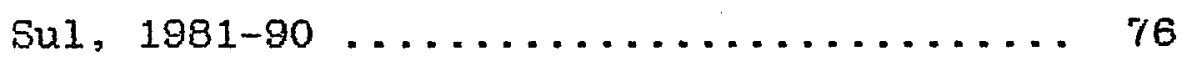

APÊNDICE 6. Consumo mensal aparente de alcool anidro para fins carburantes. NorteNordeste, 1981-90 ..................

APENDICE 7. Consumo mensal aparente de álcool hidratado para fins carburantes.

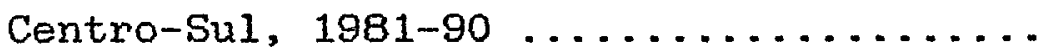


APÊNDICE 8. Consumo mensal aparente de álcool hidratado para fins carburantes. NorteNordeste, $1981-90 \ldots \ldots . . . \ldots . . . .79$

APENDICE 9. Fatores de conversão para tEP médio ..... 80 APENDICE 10. Consumo final energético de carburantes para transportes 10.1. Em volume. Brasil, 1973-90 ...... 81 10.2. Em toneladas equivalentes de petróleo .................. 82

APÊNDICE 11. Preços médios de carburantes e Produto Interno Bruto ................ 83

APÊNDICE 12. Preços de comercialização de gasolina e álcool hidratado ................ 84

APÊNDICE 13. Custos de comercializacão do álcool carburante ...................... 89

APÊNDICE 14. Frota e consumo médio de veículos a álcool ........................ 93

APENDICE 15. Valores médios anuais; álcool anidro carburante, 1981-90 .............. 94

APÊNDICE 16. Valores médios anuais; álcool hidratado carburante, $1981-90 \ldots \ldots \ldots \ldots \ldots .95$

APÊNDICE 17. Relações entre elementos de receita e elementos de despesa do Governo e o preco da gasolina ao consumidor final .... 96

APÊNDICE 18. Estimativa do saldo do Governo no período $1981-90 \ldots \ldots \ldots \ldots \ldots . \ldots . \ldots 9$

APÊNDICE 19. Projeção dos saldos do Governo. Cenário otimista, 1991-95 ............... 98

APÊNDICE 20. Projeção dos saldos do Governo. Cenário intermediário, 1991-95 ........... 99

APÊNDICE 21. Projeção dos saldos do Governo. Cenário pessimista, 1991-95 ............. 100 


\section{LISTA DE TABELAS}

$\underline{\text { Página }}$

Tabela 1. Estimativa da evolução do PIB (\% em relação ao ano anterior) ............. 40

Tabela 2. Projeção da evolução dos precos médios ao consumidor final dos combustiveis para transportes (\% em relação ao ano

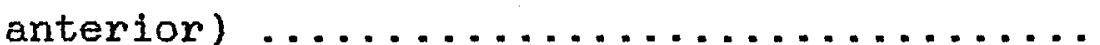

Tabela 3. Projeção da relação de preços entre combustiveis ciclo otto e diesel .........44 43

Tabela 4. Projeções das taxas de mistura de álcool anidro à gasolina ............... 45

Tabela 5. Projeções do preço da gasolina ao consumidor final (Cr\$/litro, valores de

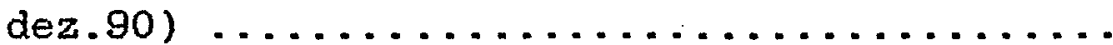

Tabela 6A. Projeção das relações entre elementos de receita e elementos de despesa do Governo na comercialização de álcool carburante e o preco da gasolina ao consumidor final. Alcool anidro (valores de $\left.\Sigma a_{i}-\Sigma b_{j}\right) \ldots \ldots \ldots \ldots \ldots \ldots \ldots \ldots .48$

Tabela 6B. Projeção das relaçōes entre elementos de receita e elementos de despesa do Governo na comercialização de álcool carburante e o preco da gasolina ao consumidor final. Álcool hidratado (valores de $\Sigma h_{i}-\Sigma g_{j}$ ) .............. 49

Tabela 7. Ajustamento estatistico das funçóes de demanda total por combustivels e de relação entre demandas por diesel e ciclo

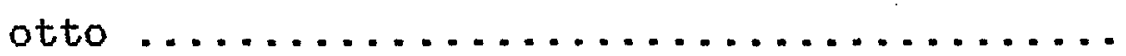


ix.

Página

Tabela 8. Saldos anuais do Governo na comercialização de álcool carburante (1981-90)

53

Tabela 9. Projeções do saldo do Governo na comercialização de álcool carburante. Brasil, 1991-95 ...................... 54 


\section{Lista de Siglas e Abreviaturas}

AEAC. Álcool etilico anidro carburante.

AEHC. Álcool etílico hidratado carburante.

ANFAVEA. Associação Nacional de Fabricantes de Vefculos Automotores.

BACEN. Banco Central do Brasil.

bep. Barril equivalente de petróleo.

COPERSUCAR. Cooperativa de Produtores de Cana, Acúcar e Álcool do Estado de São Paulo Ltda.

CIF. Cost, insurance and freight.

CENAL. Comissão Executiva Nacional do Álcool.

CNAL. Conselho Nacional do Álcool.

CNP. Conselho Nacional do Petróleo.

CTA. Centro Tecnológico Aeroespacial.

DNC. Departamento Nacional de Combustíveis.

FGV. Fundação Getúlio Vargas.

FND. Fundo Nacional de Desenvolvimento.

FOB. Free on board.

GLP. Gás Liquefeito de Petróleo.

IAA. Instituto do Açúcar e do Álcool.

IAPAS. Instituto de Administração Financeira da Previdência Social (N.A. Sigla à época da citação).

IBRE. Instituto Brasileiro de Economia (FGV).

ICM. Imposto sobre Circulação de Mercadoriae.

ICMS. Imposto sobre Circulacão de Mercadorias e Servicos. IGP-DI. Indice Geral de Precos - Disponibilidade Interna. INPM. Instituto Nacional de Pesos e Medidas. IOF. Imposto sobre Operaçöes Financeiras. IVV. Imposto sobre Vendas a Varejo. 1b. Libra-peso. 
xi.

MINERA. Ministério da Infra-Estrutura.

MIC. Ministério de Indústria e Comércio.

ME. Ministério de Minas e Energia.

OPEP. Organização de Países Exportadores de Petróleo.

PETROBRÁS. Petróleo Brasileiro S.A.

PIB. Produto Interno Bruto.

PIS. Programa de Integração Social.

PLANALSUCAR. Programa Nacional de Melhoramento da Cana-deAçúcar (IAA).

PROÁlCOOL. Programa Nacional do Álcool.

PVD. "Posto Veículo Destilaria".

PVU. "Posto Veiculo Usina".

SDR. Secretaria de Desenvolvimento Regional da Presidência da República.

SEPLAN. Secretaria de Planejamento da Presidencla da República.

STI. Secretaria de Tecnologia Industrial (MIC).

tEP. Tonelada equivalente de petróleo.

TRU. Taxa Rodoviária única. 


\section{ESTIMATIVA DO SALDO DO GOVERNO \\ NA COMERCIALIZAÇ̃̃ DE ÁLCOOL CARBURANTE}

Autor: CAETANO BRUGNARO Orientador: PROF.DR.JOSE FERREIRA DE NORONHA

RESUMO

A comercialização de álcool carburante no Brasil ocorre com a participação governamental, motivando uma polêmica sobre suas receitas líquidas.

Os objetivos principais deste estudo são analisar as estruturas de formaça dos precos dos combustíveis para estimar os saldos do Governo na comercialização de álcool carburante e desenvolver modelo matemático que possibilite estimar os saldos em cenários construídos a partir de hipóteses econômicas alternativas.

As estruturas de pregos analisadas foram as estabelecidas pelo Governo, nos niveis de produção, distribuição e varejo. As funções matemáticas de demanda total por combustiveis para transportes e de relação entre demandas por óleo diesel e ciclo otto foram ajustadas estatisticamente por um método de minimos quadrados em três etapas.

Utilizando-se projecooes intuitivas, construiram-se três cenários (otimista, intermediário e pessimista), sobre os quais se aplicou o modelo matemático desenvolvido para estimar o saldo do Governo.

Os resultados mostram que, no periodo 1981-90, os saldos foram sempre positivos. As projeçöes para o período 1991-95 revelam saldos positivos nos cenários otimista e intermediário, e saldos negativos a partir de 1992 no cenário pessimista. 


\title{
GOVERNMENT NET INCOME ESTIMATION
}

\section{IN THE FUEL ALCOHOL MARKETING}

\author{
Author: CAETANO BRUGNARO \\ Adviser: PROF.DR.JOSE FERREIRA DE NORONHA
}

\section{SUMMARY}

Fuel alcohol marketing in Brazil is realized with governmental participation, arising a polemic about the government's net income.

The main objectives of this study are to analyze the fuel price formation structures in order to estimate the governmental net income in fuel alcohol marketing and to develop a mathematical model to forecast these estimates under alternative economic scenarios.

The price formation structures analyzed were those established by the government for production, delivery and retailing of fuel alcohol.

The mathematical models of total fuel demand for transportation and for relations between diesel and otto-cycle fuel demands were statistically adjusted by a three pass least square method.

By means of intuitive projections three scenarlos were set-up - an optimistic, an intermediary and a pessimistic - and the mathematical model developed was applied to them.

The results show that in the 1981-90 period the net income was always positive. The projection for the 1991-95 period shows positive net incomes in the optimistic and intermediary scenarios and negative net incomes starting from 1992 in the pessimistic scenario. 


\section{INTRODUÇÃo}

o ano de 1973 é, usualmente, apontado como o início do fim de uma era de energia barata produzida a partir de combustiveis fósseis. Naquele ano, a OPEP surpreendeu o mundo com sua decisão de elevar substancialmente os preços do petróleo, passando-os de US\$ 6,41 por barril (aproximadamente 159 litros), em 1973, para algo em torno de US\$ 18,74 por barril em 1974, ambos os valores em dólares americanos de 1980, segundo dados de F. O. Litch citados por BORGES et alii (1983). As importaçōes brasileiras brutas do produto que, em 1973, consumiam cerca de US $\$ 711$ milhões, exigiram cerca de US $\$ 2,84$ bilhões em 1974, valores correntes FOB. Esses valores representaram, respectivamente, $11,48 \%$ e $22,47 \%$ do valor total das importaçōes e consumiram $11,47 \%$ e $35,72 \%$, respectivamente, das receitas conseguidas com exportaçōes (Conjuntura Econômica, 1978).

Isso acabou por abalar a economia de países, principalmente os não comunistas, altamente dependentes da importação de petróleo e seus derivados, como o Brasil que, em 1973 , importava quase $77 \%$ de suas necessidades desses produtos (MME, 1988).

De início, o governo brasileiro concentrou sua atenção principal no aumento da produção interna de petróleo (BORGES et alii, 1983) mas, ao contrário do que se poderia esperar, o Brasil continuou altamente dependente do produto importado que, inclusive, aumentou sua participação no consumo total, atingindo quase $85 \%$ em 1979, declinando a partir daí e chegando a $46 \%$ em 1987 (MME, 1988). 
Entre outros programas governamentais tidos como destinados a reduzir a dependêncla brasileira de fontes externas de energia - conservaçäo de energia, programas do carväo e do xisto, etc. - em fins de 1975 criou-ze o PROÁLCOOL - Programa Nacional do Álcool - com vistas a aumentar a produção de álcool para substituir parte dos derivados líquidos de petróleo.

A propósito, a utilização de álcool carburante tornou-se legalmente obrigatória com o Decreto no 19.717 , de 20/02/31, que determinava um mínimo de $5 \%$ de etanol em mistura à gasolina importada, embora haja registro do uso do produto, em substituição a derivados de petróleo, desde a Primeira Guerra Mundial (PAMPLONA, 1984).

A implantação do PROÁLCOOL é usualmente dividida em duas fases principais. A primeira delas caracterizou-se pelo objetivo de se aumentar a producão de álcool etílico anidro, a partir da cana-de-acúcar, para mistura em maior proporção à gasolina, cuja tecnologia já era conhecida e utilizada. Esea estratégia - mistura de maior parcela de anidro à gasolina, eliminando-se o chumbo tetraetila (antidetonante) - não exigiu providências adicionais de vulto por parte da indústria automobilistica nem das companhias distribuidoras de combustiveis.

Esta primeira fase, conhecida popularmente como "era do álcool barato", apoiou-se no aproveitamento da capacidade ociosa das usinas de açucar existentes, que tinham possibilidades de expansäo das lavouras e que haviam passado, há poucos anos, por um extenso programa de ampliacão e modernizacão de suas plantas industriais e não necessitaram fazer investimentos pesados em equipamentos de

\footnotetext{
1 Menciona-se, amiude, uma terceira fase do proflcool, de desenvolvimento tecnológico $\theta$ reducão de custos, mas de que não se lem um acompanhamento esguro.
} 
moagem e caldeiras, itens responsáveis por grande parcela dos custos de implantação de uma unidade industrial de produção de álcool ${ }^{2}$.

Paralelamente, os pregos do acúcar no mercado intemacional experimentavam forte declínio, caindo dos US\$ $0,5663 / 1 \mathrm{~b}$ em novembro de 1974 - pico histórico de preços - para US\$ 0,1550/1b em setembro de 1975, cotações médias em valores correntes do açúcar demerara na Bolsa de Nova Yorque (Informe Estatístico Semestral no 9, 1986). Embora pouco mencionado, também se atribui a esse fato peso importante, como motivador de pressão pelos usineiros, na decisão de se criar um programa governamental capaz de dar vazão às capacidades agricola e industrial então existentes. Registre-se que a queda de precos manteve-se até bem além dessa época. Por exemplo, em outubro de 1977 , a cotação média foi de US\$ $0,0709 / 1 b$, para o mesmo produto e no mesmo mercado.

Em 1979, novo aumento repentino dos pregos do petróleo ("segundo choque") exigiu um posicionamento mais forte das autoridades; o valor da importaça líquida do produto, que já representava $28,8 \%$ das importaçós totais em 1978, passou a $40,8 \%$ em 1980 e chegou a $44,4 \%$ em 1982 (MME, 1988). Em valores correntes FOB, os gastos com importagões brutas corresponderam a US $\$, 20$ bilhões, em 1978, US\$ 9,84 bilhões em 1980 e US\$ 10,12 bilhões em 1982, representando, respectivamente, $30,67 \%, 42,8 \%$ e $52,18 \%$ das importağones totais e $33,15 \%, 48,89 \%$ e $50,16 \%$ do valor total das exportacōes (Suma Econômica, 1989).

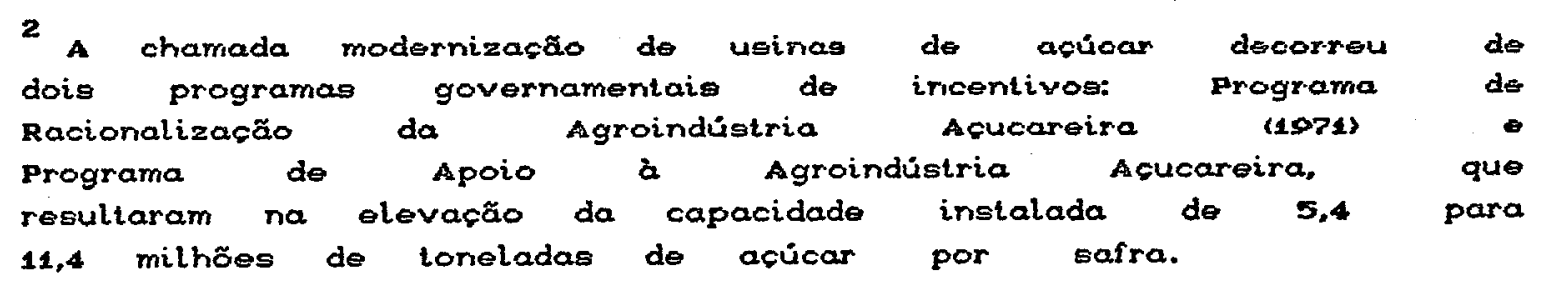


Por esea época, já era conhecida uma experiência do CTA - Centro Tecnológico Aeroespacial - de São José dos Campos-SP, que adaptara motores de automóvel ciclo otto para uso exclusivo de álcool etílico hidratado, experiência essa que se notabilizou por um périplo de milhares de quilômetros, por diversos estados brasileiros, encerrado, de forma apoteótica, na Capital Federal, na presença do então Presidente da República, e com ampla cobertura dos meios de comunicacão de massa.

A indústria automobilistica, até então relutante em realizar modificaçōes de grande porte em seus projetos de motores e linhas de montagem, sob alegação de insegurança quanto à regularidade no abastecimento de álcool, viu-se forcada a negociar com o Governo, firmando um protocolo em que se comprometia a fabricar veiculos equipados com motores para consumo exclusivo de álcool hidratado. Fixaram-se as seguintes metas: $250 \mathrm{mil}$ veículos em 1980; $300 \mathrm{mil}$ em 1981 e $350 \mathrm{mil}$ em 1982. Além disso, as oficinas autorizadas pelo governo converteriam, até o final de 1982, cem mil motores, originalmente a gasolina, para consumo de álcool hidratado (BORGES et alii, 1983).

Basicamente a partir de 1980 , que pode ser considerado 0 início da segunda fase do PROALCOOL. apareceram no mercado os primeiros veiculos equipados, já na linha de montagem, com motores e acessórios para consumo exclusivo de álcool.

A resposta do setor produtivo nota-se pelo salto brusco na produção de álcool anidro, em 1977 - um ano após as primeiras providências governamentais para concretizar o programa - e pelos aumentos significativos, a partir de 1980, na produção de álcool hidratado. Como indicador, no periodo 1980-85, a área cultivada com cana-de-acúcar, no Brasil, cresceu a uma média geométrica de $9,3 \%$ ao ano, com a produção de acúcar permanecendo mais 
ou menos constante. No mesmo período, segundo IAA/PLANALSUCAR - Instituto do Açúcar e do Alcool/Programa Nacional de Melhoramento da Cana-de-açúcar - (1986), a producão de álcool passou de 3,7 bilhões de litros (safra 1980/81) para 11,8 bilhões de litros (safra 1985/86) com grande destaque para a região Centro-Sul ${ }^{3}$ e, em especial. para o Estado de São Paulo.

Ao mesmo tempo, obviamente como fato correlacionado, o número de veículos a álcool passou a representar parcela cada vez maior do total fabricado, atingindo, em 1985, $84,8 \%$ das vendas totais da indústria automobilística no mercado interno. Essa participação foi de $75,7 \%$ em 1988 , decrescendo nos anos seguintes.

- grande crescimento da agroindústria alcooleira e de sua importância relativa na economia nacional, ao lado do número de proprietários de veículos leves a álcool elevando-se rapidamente, acabaram por tornar complexo o processo de decisão da polftica econômica governamental em relação ao produto. Lembre-se que a intervenção do Governo é total ou bastante intensa na política energética, especialmente de produção, distribuição e preços, tanto de derivados de petróleo como de álcool.

Para o petróleo, o Governo, através do CNP - Conselho Nacional do Petróleo - (atualmente DNC) e da PETROBRÁS - Petróleo Brasileiro S.A. - principalmente, avoca o estabelecimento de precos e monopoliza a pesquisa,

\footnotetext{
3 Tradicionalmente, cosiurna-se dividix o Brasil am duas grandes regiốes canavieiras: (1) Deritro-sul, compreondendo os Estados de sáo Paulo, Mirras aeraia, Paraná, Rio de Janeiro, Goids, Tocantins, Espirito santo, Mato arosso, Mato Grosso do sul, Santa catarina - Rio arande do sul; (2) Norte-Nordeste, englobando Alagoas, Pernambuco, Paraiba, Bahia, sergipe, Rio arande do Norte, Ceará, Maranhão, Piaui, Pará, Amazonas, Acre, Rondônia, Amapá e Roraima.
} 
a extracão e o refino, excecão feita a duas empresas refinadoras particulares e aos chamados "contratos de risco" para prospecgão. Somente nas fases de distribuicão e revenda dos produtos é que participam ativamente empresas privadas, ao lado da própria empresa estatal (Petrobrás Distribuidora S.A.).

No caso do álcool; o Governo estabelece as quantidades a produzir (planos de safras do ex-IAA Instituto do Acúcar e do Álcool - atualmente sob coordenação da SDR - Secretaria de Desenvolvimento Regional) e os precos ao produtor, que são variáveis por região do país.

Os preços ao consumidor, tanto de derivados de petróleo como de álcool carburante, também estabelecidos pelo Governo, têm sido uniformes em todo o território nacional. Esta uniformidade, entretanto, poderá estar deixando de existir com a implementação de dispositivos constitucionais recentes a respeito de tributação de combustiveis de alcada dos municipios (IVV - Imposto sobre Vendas a Varejo), até um máximo de $3 \%$ sobre os pregos ao consumidor, e de modificações na sistemática de cobrança do ICMS (ex-ICM) em alguns estados. Também se cogita a extinção do preço único com frete compensado.

O preço do AEHC - álcool etilico hidratado carburante - ao consumidor, num dado momento, é fixado como um percentual determinado do preco da gasolina, o que introduz uma polêmica paralela sobre qual dos dois produtos induz aumentos gerais dos precos dos combustiveis, assunto este que não se propõe discutir neste trabalho.

Em adição, a politica de precos tem implicaçöes de ordem energética, econômica, tributária e social.

Encontra-se em EERNANDES \& CASTRO (1986), sobre o tema: "Resultam dal complexos e sofisticados sis- 
temas de administração centralizada de pregos, calcadoe, no caso em questão, em normas estipuladas pelo Conselho Nacional do Petróleo e pelo Instituto do Açúcar $\theta$ do Álcool, em suas respectivas áreas de competência, sob a coordenação da Secretaria de Planejamento da Presidencla da República e com base em diretrizes gerais da Comissão Nacional de Energia, através das quais são processadas substanciais transferências intersetoriais, interregionais e intergovernamentais de recursos, tanto dentro dos setores diretamente envolvidos quanto para fora deles, ou mesmo, excepcionalmente, de outros setores econômicos para essas áreas.

A complexidade desses sistemas, allada so fato de que as "caixas" governamentais, ao contrário das leis da física, nem sempre se comportam como vasos comunicantes, provoca, frequentemente, acesos debates sobre 'quem ganha' ou 'quem perde' entre os diversos segmentos abrangidos por esses sistemas, isto é, órgãos de Governo, produtores de açúcar e de álcool, refinadores, distribuldores e revendedores de petróleo e os consumidores finais.

Ainda mais grave, a falta de transparência desses sistemas e o consequente desconhecimento de seus reais mecanismos de funcionamento induzem, frequentemente, a conclusões apressadas por parte dos observadores externos que, a partir de dados parciais ou isolados, procuram extrair inferências pontuais cuja validade flca prejudicada pela necessidade de análises mais amplas e dinâmicas."

Os autores concluem que:

“[...] - as estruturas de precos do álcool hidratado apresentavam atuaçoes alternadas, mostrando-se ora superavitária e ora deficitária; em janeiro de 1984, o álcool hidratado transferia para dentro do setor combustiveis, via CNP, mais recursos (Cr\$50,3014/1itro) que a gasolina (Cr\$39,5414/litro); já em abril, essa 
situação se invertia: o álcool recebia recursos no montante de $\operatorname{Cr} \$ 10,9493 / 1$ itro, enquanto a gasolina transferia Cr\$ 23,2607/litro;

- o diferencial arrecadado pela PETROBRÁS na comercialização do álcool anidro manteve-se sempre positivo, variando entre $\operatorname{Cr} \$ 237,3939 \mathrm{em}$ abril e $\operatorname{Cr} \$ 263,1446$ em janeiro $[\ldots] . . ”$

Confrontem-se agora essas conclusões com algumas publicaçöes da imprensa à época citada, tomadas como meros exemplos da diversidade de pontos de vista sobre - mesmo assunto:

"[...] O governo manteve incentivos fiscais e crediticios, chegou a exportar álcool [...]. Pode-se estipular em aproximadamente $\operatorname{Cr} \$ 20,00 / 1$ itro o subsidio existente atualmente $[\ldots] . "$ (O Estado de São Paulo, $07 / 01 / 84)$.

“Os produtores de álcool de todo o pais estão empenhados em conseguir, do Governo, autorizaçäo para criar uma distribuidora do produto junto aos postos. de abastecimento [...] revelou ontem 0 presidente da Associacão Nacional dos Produtores de Alcool [...]. Ele citou, por exemplo, que o Governo paga $\operatorname{Cr} \$ 250$ por um litro de álcool antdro e o revende a $\operatorname{Cr} \$ 453$ misturado a gasolina, auferindo lucros consideráveis que não são repassados ao setor alcooleiro." (Gazeta de Alagoas, $03 / 01 / 84)$.

A dicussão sobre o saldo do governo, se positivo ou negativo, continua até hoje.

Alguns dispositivos legais que regulamentam a produção e comercialização de combustivels, e que, por isso, têm influência direta na formação de seus preços, são apresentados no Cap. 4. 


\section{O Problema}

Considerando-se Governo como o conjunto de estruturas do Poder Executivo nas esferas federal, estaduais e municipais e IAA, CNP (extintos, tendo parte de suas atribuicões sido absorvidas por outros órgãos governamentais) e PETROBRÁS (esta, nas fases de aquisicão, coleta, mistura, estocagem e venda de álcool às distribuidoras) como órgãos governamentais, existe, então, um fluxo financeiro, com receitas (tributos e venda de álcool às distribuidoras) e despesas (aquisição de álcool dos produtores, subsidios de equalizacão de custos, transporte, mistura do anidro à gasolina e armazenagem), cujo saldo tem sido motivo de discussões já mencionadas anteriormente.

Essa abordagem não permite, principalmente do lado das receitas do Governo ${ }^{4}$, quantificar que parte do montante envolvido cabe à esfera federal e, portanto, não se pode concluir se a "PETROBRÁS", a quem erroneamente o conceito popular tem atribuido toda a operacionalização da politica de combustiveis, vem tendo saldos positivos ou negativos.

- conhecimento do sinal (positivo ou negativo) do saldo afigura-se importante, tanto para diretrizes econômicas de governo como para julgamento da

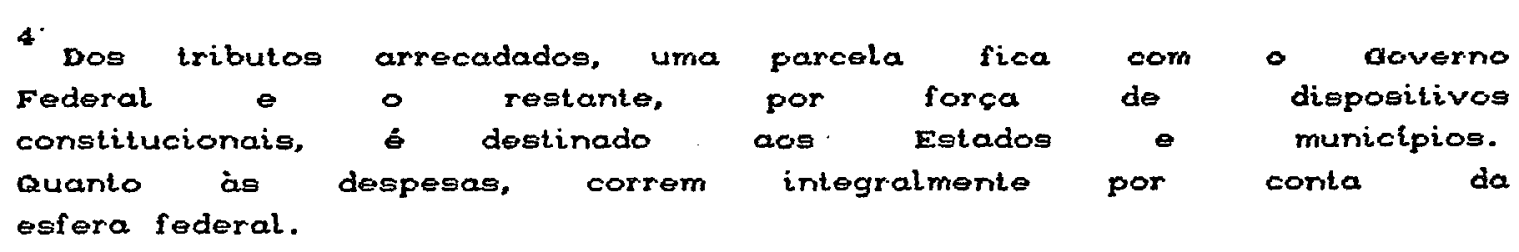


sociedade. Saldos positivos significam que o "programa do álcool" não subtrai recursos, que säo escassos, do montante global disponivel e, portanto, não diminui o atendimento de outras necessidades sociais, contribuindo, pelo contrário, para facilitar sua obtencão. Em contrapartida, saldos negativos significam a imposição de sacrificios adicionais à sociedade, drenando recursos de outros programas em favor do chamado transporte individual de passageiros.

Pretende-se verificar se, mesmo que tenha havido déficits temporários, os saldos anuais do Governo têm sido positivos.

A produção de álcool é planejada pelo IAA, ou seu sucessor na politica canavieira (planos de safras). tomando como referências: (1) "estimativas de safras", cujos dados são basicamente fornecidos pelas usinas e destilarias en função de suas próprias expectativas ou intenções de produção; (2) ajustes em função de outros indicadores, como desempenho anterior das unidades produtoras em relação às produções planejadas; (3) expectativas de mercado para o acúcar; (4) ajustes durante a safra, e outros. A partir de 1990, deixou de existir uma estimativa de safra conduzida pelo governo nos moldes relatados acima.

Deste modo, não há, formalmente, planejamento da produção de álcool carburante em função da demanda prevista por este produto, embora esta possa ser levada em conta de maneira empirica e apesar de disponível em diversos estudos.

Projecooes de demanda (e oferta) de álcool carburante têm sido feitas principalmente por órgãos oficiais ou seus técnicos, citando-se como exemplos os trabalhos de OLIVEIRA \& ALVIM (1985) e do MIC/STI (1984). Nesses trabalhos, a preocupação principal é com excedente ou escassez de oferta, e não com o saldo do Governo. 
Em documento do WORLD BANK (s. d.), encontram-se projeçoes de demanda por álcool carburante, estimativas de custos e benefícios econômicos do PROÁLCOOL e análise de impactos fiscais e de incentivos do programa. Entretanto, não entra na discussão do saldo do Governo na comercialização de álcool carburante.

Já no trabalho de PELIN (1985), que conclui pela desvantagem do álcool hidratado em relação, principalmente, à gasolina, a metodologia utilizada contempla custos e beneficios sociais e, portanto, não serve para comparações com o que se pretende neste trabalho.

Em projeto elaborado pela Fundação João Pinheiro (1986), sob patrocinio do MIC/STI - Ministério de Indústria e Comércio/Secretaria de Tecnologia Industrial apresenta-se um modelo de monitoria dos fluxos financeiros envolvidos na produção e comercialização de álcool etílico. Entretanto, os poucos resultados, obtidos a titulo de exercicio, para alguns meses de 1985 e 1986, não são completos ou conclusivos.

Mesmo em trabalho da COPERSUCAR (1889), entidade que congrega usinas e destilarias responsáveis por mais de $36 \%$ de toda a produção autorizada para a região Centro-Sul na safra 1988/89 (cf. IAA), encontra-se menção a "aspectos contábeis do PROÁLCOOL", mas trata-se de apenas duas estruturas pontuais de precos, em duas datas de 1988.

A atualidade do polemico tema dispensa provas, bastando atentar para o farto e frequente noticiário sobre 0 assunto apresentado nos meios de comuntcação.

Dos trabalhos analisados, relacionados ao assunto, nenhum conclui de forma inquestionável sobre o resultado final, para o Governo, da comercialização de álcool carburante. 
Desta maneira, permanece em aberto a questão de se desenvolver modelos que permitam estimar o saldo do Governo na comercialização de álcool.

A relevância futura de um estudo desta natureza depende, em boa parte, do grau de intervenção governamental no setor. Na hipótese extrema de privatização total do mercado de combustíveis, é evidente que este trabalho perderá muito de seu significado, visto que o Governo passaria a ter apenas receitas, representadas pelo recolhimento de tributos.

Contra esea possibilidade, entretanto, levantam-se dispositivos constitucionais sobre monopólio do petróleo (art.177 da Constituição Federal) aliados à perspectiva bastante provável de a gasolina automotiva continuar recebendo adição de álcool anidro. Desta maneira, no médio prazo, mesmo que toda a comercializacão do álcool hidratado venha a se dar pela iniciativa privada, pelo menos o álcool anidro tende a se manter no âmbito de órgãos estatais. 


\section{Ob.jetivos}

Geral: Analisar a estrutura de formaçäo dos custos e preços dos combustiveis automotivos para:

3.1. Estimar os saldos do Governo na comercializaçäo de álcool carburante;

3.2. Desenvolver modelo matemático, para simulação em cenários, que possibilite estimar o saldo do Governo sob hipóteses econômicas alternativas. 


\section{Metodologia}

4. 1. Estrutura de precos dos derivados de petróleo

Tomando-se como base o trabalho de FERNANDES \& CASTRO (1984), apresentam-se a seguir as estruturas de precos dos derivados de petróleo e do álcool carburante. A obra mencionada sustenta as informações contidas até o final do item 4.2.2.

Inicialmente, são fixados os preços básicos dos produtos derivados de petróleo. Como há uma grande diversificação de produtos, considera-se inviável, na prática, determinar custos individuais de cada ụm deles; calcula-se, então, um preço médio capaz de cobrir os custos e a rentabilidade das refinarias.

Consideram-se quatro grupos de despesas: (1) Custos em função dos preços internacionais do petróleo e outros materiais importados e da taxa de câmbio; (2) Despesas com pessoal; (3) Outros custos variáveis; (4) Depreciação e remuneração do capital. Pelo somatório desses itens, obtém-se o "preço médio de realizacão exrefinarias.5

A aplicacão direta desse procedimento esbarra em algumas dificuldades:

\footnotetext{
5 Trata-se, grosso modo, do custo médio de refino do po petró-
leo para obtencăo de seus derivados, ocrescido da margem de lucro da refinaria.
} 
a) Existência de sucedâneos, cujos preços são formados fora do "setor petróleo"; ex.: para óleo combustivel, existem substitutos como lenha, carvão, bagaço de cana e eletricidade;

b) Politicas de ordem econômica e social; ex.: a nafta para fertilizantes e petroquímioa tem seus preços fixados abaixo do preço médio, vieando manter competitividade com os precos internacionais (natureza econômica); ao GLP também se atribuem preços abaixo do preço médio (natureza social).

Como resultado, tem-se, em lugar do preço médio, uma série de precos individuais de derivados de petróleo, precos estes ponderados pelas participaçōes respectivas de cada produto no mercado, de tal forma que as receitas totais cubram os custos totais. Uma consequência imediata deste fato é que podem ocorrer transferencias intersetoriais, internas à estrutura de preços, e que, por este motivo, não são claramente percebidas.

No caso do álcool carburante, entretanto, ocorrem transferências ajustadas por fora da estrutura - como, por exemplo, as decorrentes do nivel de precos fixados aos produtores - e que, por serem mais visiveis, acabam por gerar conflitos de interesses.

A partir do preço de realização, agregam-se tributos, obtendo-se os precos de faturamento na refinaria. Os principais tributos, nesta fase, são:

(1) Imposto único sobre combustiveis e lubrificantes líquidos e gasosos e seu adicional, tendo como base o Decreto-lei no 1785, de 15/05/80; leva em conta - custo CIF do petróleo importado e alíquotas diferenciadas por produto;

(2) Repasse do IOF - Imposto sobre Operacões Financeiras - também de forma diferenciada; os 
recursos são recolhidos pela PETROBRÁS ao Tesouro Nacional, que os repassa ao Fundo de Unificação de Preços, gerido pelo CNP, com vistas à viabilizagão de precos uniformes em todos os municipios do país, isto é, os recursos destinam-se a compensar as diferenças de fretes.

(3) Quota de Previdencia, de acordo com o decreto-lei no 2.102, de $21 / 02 / 83$, de até $6 \%$ do prego ex-refinaria da gasolina " $A$ " $e$ incidente sobre todos os combustiveis automotivos; os recursos desta forma captados são repassados ao Fundo de Liquidez da Previdência Social. Posteriormente, o percentual máximo passou a $12 \%$;

(4) PIS/PASEP - Programa de Integraçäo Social/Programa de Formação do Patrimônio do Servidor Público - refinaria: calculado com aliquotas de $0,8 \%$ e $0,75 \%$ sobre o faturamento, para refinarias estatais e particulares, respectivamente; repassado de forma diferenciada aos produtos;

(5) Finsocial refinaria (Decreto-lei no 1940 de 25/02/82): $0,5 \%$ do faturamento, também repassado de forma diferenciada;

(6) ICM - Imposto sobre Circulação de Mercadorias - incidente apenas sobre alguns produtos (asfaltos, parafinas e derivados aromáticos).

Sobre os pregos individuals de faturamento incidem novos tributos que, agregados aos custos de comercialização, dão como resultado os preços finals ao consumidor. São os seguintes:

(1) Encargos de distribuição: custos e margem de lucro das empresas distribuidoras de derivados de petróleo e álcool;

(2) Finsocial distribuição: $0,5 \%$ do faturamento das distribuidoras; a partir de 1989, a aliquota passou a ser de $1,2 \%$ e de $2 \%$ em abril de 1991; 
(3) Encargos de revenda: custos e margem de lucro dos postos de revenda, com base em planilha de um "posto padrão" (130 mil litros de combustíveis por mês);

(4) Finsocial revenda: $0,5 \%$ do faturamento dos postos; a partir de 1989: 1,2\%; a part1r de abril de 1991: $2 \%$.

Entre 25/07/86 e 17/10/88, o Governo cobrou dos consumidores de AEHC e de gasolina o chamado empréstimo compulsório, que não é, conceitualmente, um tributo.

4.2. Estrutura de precos do álcool carburante

De modo geral, a estrutura de preços da cana-de-açúcar, do açúcar e do álcool sustentava-se em planilhas elaboradas pelo IAA ${ }^{\sigma}$ e submetidas à homologação da SEPLAN. Os levantamentos de custos, que embasam as proposiçōes de preços, eram realizados sob a égide de convênio entre o IAA e FGV/IBRE - Fundação Getúlio Vargas/ Instituto Brasileiro de Economia.

Com base no preco estabelecido para o açucar, calculam-se os preços do álcool. De início, toma-se a chamada paridade econômica que, teoricamente, estabelece - ponto de indiferenca para o usineiro entre produzir açúcar ou álcool. Partindo-se de 1980, a paridade assumiu os seguintes valores, expressos em litros de álcool absoluto (100. INPM - Instituto Nacional de Pesos e Medidas) por $60 \mathrm{~kg}$ de acúcar cristal standard: 39 até 17/05/81; 38 até 02/07/87 e 37 daí em diante.

A partir deste parâmetro, estabelecem-se os

\footnotetext{
Atualmente, pelo órgão federal que absorveu parte de suas funcôes, a secretaria de Desenvolvimento Regional da Pregidência da República.
} 
valores de paridade do álcool anidro e do álcool hidratado. Adicionando-se a tributação incidente sobre a matéria-prima (PIS, Finsocial e J.CM) e diferida para o momento da comercialização dos produtos, obtêm-se os precos de paridade ${ }^{7}$ do anidro $e$ do hidratado. Agregando-se ai os tributos sobre o faturamento da destilaria - no caso do álcool carburante, PIS e Finsocial - resultam os precos de aquisicão ao produtor na condição PVU ou PVD ("posto veiculo usina"; "posto veículo destilaria"), isto é, uma espécie de preço FOB destilaria.

A estrutura de pregos do álcool carburante, no nível de produção, está exemplificada no Apêndice 1.

Além dos preços de aquisição, os produtores de álcool de determinadas regiões habilitavam-se, até 1990, a receber os chamados subsídios de equalizaçáo de custos. Legalmente, o subsídio só é devido ao álcool direto, isto é, obtido diretamente de caldo de cana, e não de mel residual da fabricação de açúcar (álcool residual). A partir de 07/11/1990, o subsídio deixou de constar explicitamente das planilhas de formaça de preços. Entretanto, os valores de paridade, tanto do anidro como do hidratado, que até então eram uniformes em todo o país, passaram a ser diferenciados para os estados do Norte-Nordeste e para o Rio de Janeiro. De qualquer forma, tanto se considerando subsidios como valores de paridade diferenciados (maiores nas regiões citadas), sempre se trata de desembolso do Governo.

Para se entender a formação dos preços finais ao consumidor, é necessário considerar separadamente - álcool anidro e o hidratado.

Encontra-se, as vezes, o termo subtotal. 


\subsection{Anidro}

Ao preço ao produtor somam-se: (1) Fretes entre destilaria e centro de mistura, de acordo com planilha do CNP (atual DNC); (2) Taxa de servico do centro de mistura, equivalente a $2 \%$ do valor de paridade; (3) Quota de Previdência. Chega-se, assim, aos precos do álcool anidro posto nos centros de mistura. A partir daí, passa a ser faturado ao preco da gasolina e a incorrer em seus tributos.

Salvo por coincidência, existe um diferencial entre o custo do anidro posto no centro de mistura e seu preço de faturamento. A PETROBRÁS realiza toda a aquisição e recolhe o diferencial de precos para, basicamente, cobrir custos de manutencĩo de estoques e regular flutuações sazonais de oferta e demanda de álcool.

\subsubsection{Hidratado}

Os custos de colocação nos postos de revenda são semelhantes aos do anidro, não existindo, obviamente, os encargos de mistura. Os pregos ao consumidor, entretanto, são vinculados aos da gasolina, através de um percentual predeterminado (que tem variado ao longo do tempo).

Outro fato: os reajustes de precos, ao produtor e ao consumidor, geralmente não são simultâneos, o que, combinado com o diferencial de precos do anidro e com a politica de preços uniformes em todo o territorio nacional, pode gerar duas situaçoes distintas: (a) Custos do álcool compatíveis com seu preço de faturamento, podendo gerar superávits; (b) Incompatibilidade temporária.

Acrescente-se que, até 1983, existia uma espécie de "conta única", com o CNP recolhendo as 
diferencas positivas (entre precos e custos) ou arcando com as diferencas negativas. A partir de 1984, entretanto, em consequência da chamada Emenda Passos Porto, o diferencial positivo passou a ser recolhido à PETROBRÁS e o diferencial negativo a ser coberto pelo CNP, o que tornou bem mais complexa a administração do sistema de preços.

\subsection{Tributaç̃o na fase agrícola}

Sobre o valor da produção agrícola incide tributação do Funrural, a uma alíquota de 2,5\%. Até 1985, incidia sobre o preco da cana no campo (uma espécie de preço FOB). A partir de 1986, passou a incidir cobre o preco da cana na esteira (CIF), exclusive PIS e Finsocial, isto é, passou a tributar também os valores atribuídos a trensporte e a ICM, de acordo com IAPAS/SAF citado em documento da Associação de Usineiros de São Paulo (1986). Como as alíquotas eram, respectivamente, de $0,75 \%$ e $0,5 \%$, o valor base para cálculo passou a ser de $98,75 \%$ do preço da cana na esteira.

Após a promulgação da atual Constituição da República Federativa do Brasil (1988), em virtude de dispositivos nela contidos, houve, a partir de 1989, alteraçós de alíquotas de tributos existentes e mesmo a criação de um novo imposto (IVV). O Finsocial, por exemplo, teve sua aliquota elevada para $1,2 \%$ ( $2 \%$ a partir de abril de 1991), e o ICM, que passou a ser o ICMS - Imposto sobre Circulação de Mercadorias e Seviços - também teve suas aliquotas alteradas.

Por outro lado, com a reforma administrativa decretada pelo Governo Federal em marco de 1990, houve mudanças na estrutura de politica e controle do setor energético, incluindo o alcooleiro. Foram extintos o MME, o CNP e o IAA, com redistribuição de parte de suas funções para outros órgãos, já existentes ou criados na oportunidade. 
Em que pesem esses fatos, permanecem as estruturas gerais de formação de preços dos combustiveis.

\section{4. Empréstímo compulsório}

No periodo de 25/07/86 a 17/10/88 vigorou o chamado empréstimo compulsório ao FND - Fundo Nacional de Desenvolvimento - criado pelo Decreto-lel no 2288, correspondendo a $28 \%$ dos preços ao consumidor da gasolina - portanto, incidindo também sobre o álcool anidro carburante - e do álcool hidratado. Incidia, ainda, eobre o preço de aquisição de automóveis novos.

A sistemática decretada para o reemboleo desse empréstimo é de tal forma confusa que "[...] corre o risco de passar à categoria jurídica de doação ou confisco. [...] Existem duas dificuldades para que o empréstimo compulsório sobre consumo de combustiveis e aquisição de automóveis possa ser restituído: o governo não sabe a quem devolver; o dinheiro que foi recolhido está bloqueado no Banco Central, sem qualquer correção desde o seu ingresso nos cofres do Tesouro." (Folha de São Paulo, 27/06/89).

Mesmo sob pena de ter sido, na prática, uma receita do governo, não se trata, conceitualmente, de um tributo. Por este motivo, seus valores não serão considerados como receitas do Governo, com a advertência de que, no periodo em que vigorou, o saldo do governo terá sido malor, caso não venha a ocorrer a devolução do compulsório aos consumidores de combustiveis.

\subsection{Modelos de análise}

Neste trabalho, a estimativa de saldos pode ser obtida em planilhas do tipo "Receitas - Despesas = Saldo", utilizando-se valores anuais. 
Serão adotados alguns pressupostos simplificadores. Primeiro: qualquer transacão produz resultados imediatos, tanto no tocante à realizacão de receitas quanto a desembolso com despesas; desta forma, não se estarão captando os efeitos financeiros (juros) de eventuais defasagens temporais.

Esta hipótese soa um pouco forte, especlalmente numa economia com elevadas taxas de juros reais. Entretanto, a defasagem que realmente ocorre na prática se, por um lado, onera o Governo com juros, por outro o beneficia sempre que ocorrem reajustes dos pregos de comercialização no intervalo compreendido entre o faturamento do álcool aos produtores e a venda às distribuidoras.

Segundo: as quantidades transacionadas de álcool serão consideradas lguais às entregues pelas destilarias para fins carburantes, invocando-se critério semelhante ao do CNP, de consumo aparente. A armazenagem faz-se principalmente nas unidades produtoras - dispositivo legal prevê a retirada uniforme do produto durante todo o ano, isto é, um doze avos da produção total por mês - ao passo que os chamados estoques estratégicos (ou de segurança) têm sido muito baixos, não chegando ao suficiente para o consumo de sessenta dias - usualmente bem menos - conforme tem-se divulgado com frequencia. A existência desses estoques é regulamentada pela Resolução no 6/80 do CNAL - Conselho Nacional do Álcool (PETROBRÁs, 1983). Mesmo assim, serẽo considerados os custos de armazenagem e das perdas decorrentes do manuseio e da evaporação, fornecidos pela PETROBRÁS.

Terceiro: a participação da PETROBRás será considerada apenas até o momento da entrega dos combustíveis às distribuidoras (inclusive à Petrobrás Distribuidora S.A.), isto é, apenas no seu papel de órgão de 
governo executor da politica de combustiveis.

Os itens a se considerar no fluxo são:

\section{A) Receitas}

- Venda de álcool às distribuidoras;

-Tributos diretos nas etapas de produção (inclusive na fase agrícola), distribuição e revenda de álcool carburante;

B) Despesas

- Compra de álcool dos produtores;

. Subsídios de equalizacão de custos;

- Custos de transporte desde as destilarias até a entrega às distribuidoras;

- Encargos de mistura do AEAC (álcool etilico anidro combustivel) à gasolina; -Custos de armazenagem, inclusive perdas.

\section{C) Saldo $(A-B)$}

Note-se que não será necessário tratar dos tributos incidentes na fase de processamento ou manuseio na refinaria, por serem gerados e recolhidos no âmbito aqui considerado como Governo.

Neste trabalho, pretende-se obter, a partir de funçōes de demanda por combustiveis para transporte, estimativas do saldo do Governo no que se refere à comercialização de álcool carburante.

Encontra-se em OLIVEIRA \& ALVIM (1985) a seguinte funcão estimada para demanda total de carburantes em função do nível de atividade econômica (adaptando-se a simbologia):

$$
\hat{D}_{t}=D_{0}\left(Y_{t} / Y_{0}\right)^{0,802},
$$


onde:

$D_{i}$ : Demanda total por carburantes, em "equivalentes gasolina", no ano $t$;

$D_{o}$ : Demanda total no ano de referencia;

$Y_{t}, Y_{0}: P I B$, em valores constantes, dos anos $t e d e$ referência, respectivamente;

$t: \operatorname{Anos}(t=1,2,3, \ldots, n)$.

En seguida, citam o modelo apresentado por Lizardo para fracionamento dessa demanda entre os ciclos diesel e otto:

$$
\hat{Z}_{t}=0,95466 \mathrm{Z}_{t-1}^{0,056} \mathrm{PR}_{t}^{0,24 \theta},
$$

onde:

Z : Relação entre demandas anuaie por diesel e por combustiveis ciclo otto, medidas em equivalentes gasolina;

PR: Relação entre pregos dos combustiveis clclo otto e do diesel;

$\hat{a}=0,95466 ; \hat{\beta}_{1}=0,956 ; \hat{\beta}_{2}=0,248$ : estimativas dos parâmetros

$t$ : Periodos $(t=1,2,3, \ldots, n)$;

Sabendo-se que $D O_{t}=D_{i}\left(1+z_{i}\right)^{-1}$, utilizando-se (1) e (2), obtém-se a expressão que dá a demanda de combustiveis ciclo otto ${ }^{\circ}$ :

- Lizardo et al. Evolucão da demanda de combugtiveis no Brasil. In: AVALIAGÃO DO PROGRAMA NACIONAL DO ALCOOL 1901/82, Anexo 3.9. Brasilia, MIC/STI, 1902.

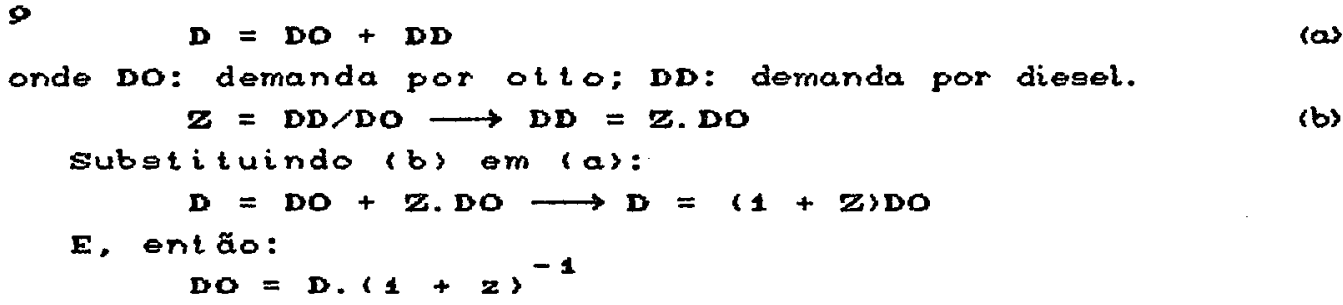




$$
\mathrm{DO}_{\mathrm{i}}=\mathrm{D}_{0}\left(\mathrm{Y}_{\mathrm{t}} / \mathrm{Y}_{\mathrm{o}}\right)^{0,002}\left(1+0,95466 \mathrm{Z}_{\mathrm{t}-1}^{\mathrm{c}, 950} \mathrm{PR}_{\mathrm{i}}^{\mathrm{C}, 248}\right)^{-1}
$$

onde DO é a demanda por combustiveis ciclo otto, no ano $t$.

Esse modelo relaciona a demanda no ano $t$ com a variaça acumulada do PIB - Produto Interno Bruto - e não leva em conta a eventual influencia dos preços no consumo.

Acrescente-se que a conversāo para "equivalentes gasolina" tomou coeficientes arbitrários constantes, a saber: 0,8 para o álcool hidratado, 1,0 para o álcool anidro e 1,4 para óleo diesel. Pelo menos para este último, e também para a gasolina, o MME - Ministério de Minas e Energia - (atualmente extinto) e posteriormente o MINERA - Ministério da Infra-Estrutura - vêm adotando coeficientes variáveis, ao longo dos anos, para conversão em unidade energética única, tEP - tonelada equivalente de petróleo - que é uma unidade aceita internacionalmente.

Os autores definem o prego relativo entre otto e diesel como o menor valor entre $\mathrm{pg} / \mathrm{pd}$ e (ph/0,8)/pd, onde pg é o preço da gasolina, ph o preço do AEHC e pd o preço do diesel. Mantêm o uso de coeficientes arbitrários constantes para conversão em "equivalentes gasolina".

Segundo BARROS (1987), tratando da elasticidade-renda da demanda, para consumo expresso em quantidade, e preferivel utilizar-se a função semi-logarítmica, em que a elasticidade-renda é inversamente proporcional à quantidade consumida. Por outro lado, em que pese a possibilidade de correlação entre renda e preços, a omissão no modelo desta última variável leva à estimação apenas da demanda potencial.

No presente trabalho, utilizando-se, porém, volumes de carburante convertidos em tEP, propõe-se ajustar 
26.

os seguintes modelos para a funçäo de demanda por combustiveis automotivos:

$$
\begin{gathered}
D_{t}=a_{0}+a_{1} \cdot \ln D_{t-1}+a_{2} \cdot \ln \frac{Y_{t}}{Y_{0}}+u_{t} \\
D_{t}=\beta_{0}+\beta_{1} \cdot \ln D_{t-1}+\beta_{2} \cdot \ln \frac{Y_{t}}{Y_{0}}+\beta_{3} \cdot \ln \frac{P M_{t}}{P M_{0}}+v_{t}
\end{gathered}
$$

onde:

$D_{t}$ : Demanda anual de combustiveis para traneporte, em $10^{\circ} \mathrm{tEP}$, no ano $t$;

$\mathrm{Y}_{\mathrm{t}} \quad$ : PIB em valores constantes no ano $t$;

$\mathrm{PM}_{\mathrm{t}}$ : Preço médio anual dos carburantes em valores constantes, tomado como a média aritmética dos precos ao consumidor de 1 tEP de "gasolina + anidro", hidratado (a partir de 1980) e diesel, no ano $t$;

$\alpha_{i}, \beta_{j}$ : Parâmetros $(i=0,1,2$ e $j=0,1,2,3)$;

$t \quad$ : Anos $(t=1,2, \ldots, n)$;

$t=0$ : Ano de referência;

$u, v$ : Erros aleatórios.

Está-se tomando os valores do PIB como Indicadores da renda, embora se trate de entes distintos.

Os dois modelos, (4) e (5), incluem valores defasados da variável dependente ao lado das variáveis independentes, fazendo-se necessário estar atento para o problema de autocorrelação nos resíduos.

De acordo com HOFFMANN \& VIEIRA (1987), discorrendo sobre o modelo matricial $\Lambda d=\Lambda \times \beta+\Lambda u$ (simbologia adaptada), "[...] o aparecimento de valores defasados da variável endógena [...] no segundo membro da equação, entre as variáveis independentes, exige uma ansilise 
especial [...]. Wallis (1967, p.565) ${ }^{10}$ sugere que seja feita, inicialmente, uma regressão de $D_{t}$ contra as varláveis exógenas, pelo método de mínimos quadrados ordinários; sejam $\hat{D}_{t}$ os valores de $D_{t}$ estimados por esesa regressão. A seguir, é aplicado o método das vartáveis instrumentais, utilizando-se $\hat{D}_{t-1}$ como variável instrumental para $D_{l-1}$, são calculados os desvios, $e$ calculado o valor de $\hat{\rho}$ " (coeficiente de autocorrelação estimado) "e, finalmente, é aplicado o método de mínimos quadrados generalizados $[\ldots]$..”

As estimativas dos parametros assim obtidas são consistentes e apresentam variancias assintoticamente consistentes. Porém, os testes de significancia dos coeficientes de regressão com base na distribuição $t$ de Student só seriam rigorosamente válidos se fosse conhecido - valor verdadeiro de $\rho$. Neste trabalho, vai-se utilizar - uma estimativa do coeficiente de autocorrelação $(\hat{p}), 0$ que torna os testes apenas aproximados, mas admissiveis.

o critério para seleção do modelo, entre os propostos, será o de que apresentar a menor soma de quadrados do residuo, dada por:

$$
\operatorname{SQReE}=d^{\cdot} \cdot \hat{v}^{-1} d-\beta \cdot X \cdot \hat{v}^{-1} d,
$$

onde $\mathrm{V}^{-4}=\Lambda \Lambda$.

Nos modelos propostos, espera-se que $a_{1} \geq 0$, $a_{2} \geq 0 ; \beta_{1} \geq 0, \beta_{2} \geq 0$ e $\beta_{3} \leq 0$.

Com referência à relação entre demandas por diesel e otto, no presente trabalho pretende-se ajustar os seguintes modelos:

\footnotetext{
10 wallis, K.F. Lagged dependent variables 'and serially correlated errors: a reappraisal of three-pass least squeres. ReV. Economies and Statistics, 40:555-507, 1967 .
} 


$$
\begin{gathered}
\mathrm{Z}_{\mathrm{t}}=\gamma_{0} \mathrm{Z}_{\mathrm{i}-1}^{\gamma_{1}} \cdot \mathrm{PR}_{\mathrm{i}}^{\gamma_{2}} \varepsilon_{\mathrm{t}} \\
\mathrm{z}=\delta_{0}+\delta_{1} \cdot \ln \mathrm{Z}_{\mathrm{t}-1}+\delta_{2} \cdot \ln \mathrm{PR}_{\mathrm{i}}+\mathrm{w}_{\mathrm{i}}=
\end{gathered}
$$

onde:

Z : relação entre demandas por combustiveis ciclo diesel e ciclo otto, medidas em tEP;

PR : preco relativo entre ciclo otto e diesel;

$\gamma_{i}, \delta_{j}$ : parâmetros $(i, j=0,1,2)$;

$\mathrm{t}: \operatorname{anos}(\mathrm{t}=1,2,3, \ldots, \mathrm{n})$;

$\varepsilon, w$ : erros aleatórios.

Serão utilzados valores convertidos em tEP, tanto para demanda como para precos, com base nos coeficientes adotados pelo MME (extinto) e pelo MINFRA.

Valem, aqui, as mesmas consideraçōes de natureza estatistica propostas para os modelos (4) e (5).

Obtidas as funçōes estimadas de demanda total por carburantes (D) e de relacionamento entre demandas por diesel e ciclo otto (Z) a demanda estimada por combustiveis ciclo otto ( $D O$ ), num dado ano $t$, pode ser obtida por:

$$
D O_{t}=D_{t}\left(1+Z_{t}\right)^{-1}
$$

Os valores assim calculados dão a demanda global, medida em $10^{\circ} \mathrm{tEP}$, de gasolina "pura" (DG), álcool anidro (DA) e álcool hidratado (DH). Portanto:

$$
D O_{t}=D G_{t}+D A_{t}+D H_{t}
$$

Simbolizando por $\mathrm{cg}$, ca e ch os coeficientes para conversão de volumes de carburantes em tEP, e por CG, CA e CH os respectivos consumos em volume $\left(10^{6} \mathrm{~m}^{3}\right)$ de 
29.

gasolina "pura", anidro e hidratado, e adotando-se $\mathrm{DO}_{\mathrm{t}}$ como - consumo total de combustíveis ciclo otto no ano $t$, tem-se :

$$
D O_{t}=c g_{t} \cdot C G_{t}+C a_{i} \cdot C A_{t}+c h_{t} \cdot \mathrm{CH}_{t}
$$

Sendo $m$ a fração volumétrica representada pelo anidro no volume total da mistura com gasolina, faz-se (para $\mathrm{m}>0$ ):

$$
\begin{gathered}
\mathrm{CG}_{\mathrm{t}}=\left(\mathrm{m}_{\mathrm{t}}^{-1}-1\right) \mathrm{CA}_{\mathrm{t}} \\
\text { Substituindo em }(9): \\
\left.\mathrm{DO}_{\mathrm{t}}=\left[\mathrm{cm}_{\mathrm{t}}^{-1}-1\right) \mathrm{cg}_{\mathrm{t}}+\mathrm{ca}_{\mathrm{i}}\right] \mathrm{CA}_{\mathrm{t}}+\mathrm{ch}_{\mathrm{t}} \cdot \mathrm{CH}_{\mathrm{t}}
\end{gathered}
$$

Mesmo sendo conhecidos os valores de $\mathrm{m}$, cg, ca e ch, a equação não permite solução única (duas incógnitas). Neste caso, é necessário pré-estabelecer o valor de uma delas. O consumo total de álcool hidratado pode ser dado por:

$$
\mathrm{CH}_{\mathrm{i}}=\mathrm{FH}_{\mathrm{t}} \cdot \mathrm{CMH}_{\mathrm{i}} \text {, }
$$

onde FH e a frota em circulação de veículos a álcool e CMH - consumo médio anual desses veículos, em volume, no ano $t$. $\mathrm{Na}$ realidade, bastaria pré-estabelecer o valor de $\mathrm{CH}$. O cálculo através da expressão proposta visa aumentar a informação no ato de se fazer as estimativas.

Substituindo (12) em (11) e isolando, vem:

$$
C A_{i}=\left(\mathrm{DO}_{t}-C \mathrm{Ch}_{t} \mathrm{FH}_{\mathrm{t}} \mathrm{CMH}_{\mathrm{t}}\right)\left[\left(\frac{1}{\mathrm{~m}_{\mathrm{t}}}-1\right) \mathrm{Cg}_{\mathrm{t}}+c \mathrm{a}_{\mathrm{t}}\right]^{-1}
$$

Desde que sejam conhecidos os valores de cg, $c a$, ch e $m$, pode-se, dispondo-se de previsões sobre os valores de $\mathrm{FH}$ e de $\mathrm{CMH}$, estimar o consumo de álcool 
hidratado [ eq.(12)] e de álcool anidro em função da demanda estimada por combustiveis ciclo otto [ eq.(13)].

No que se refere ao número de veículos, mas tratando de modelos a gasolina, OLIVEIRA \& ALVIM (1985), adotando uma função de sucateamento que pressupõe retirada completa de circulação dos veículos após 20 anos de entrada no mercado e que metade dos veículos já estarão sucateados em 12 anos, observam que $[[\ldots]$ as estatisticas brasileiras, baseadas, até recentemente, na emissão de guias de TRU, contêm uma superestimação evidente, já que os dados de frota conduzem a taxas de sucateamento negativas ao longo dos cinco primeiros anos para veículos de passeio. A frota obtida para veículos a gasolina a partir da função adotada e do número de veículos vendidos no mercado interno (desprezando os importados) é sensivelmente inferior às estimativas de frota atuais."

Para veículos a álcool, entretanto, existem disponiveis estimativas de frota e de consumo especifico médio (DATAGRO, 1991), conforme anotado no Apêndice 14.

Uma das expressões que podem relacionar 0 saldo do governo com os consumos de álcool anidro e de álcool hidratado é a seguinte:

$$
S G_{t}=\left[\mathrm{CA}_{t}\left(\sum_{t=1}^{2} a_{\mathrm{it}}-\sum_{j=1}^{3} \mathrm{~b}_{j t}\right)+C \mathrm{CH}_{\mathrm{i}}\left(\sum_{i=1}^{2} h_{\mathrm{it}}-\sum_{j=1}^{2} \mathrm{~g}_{j \mathrm{t}}\right)\right] P \mathrm{PG}_{\mathrm{i}}-\mathrm{CTE}_{\mathrm{t}}
$$

onde:

SG: saldo anual do Governo, em $\operatorname{Cr} \$ 10^{\circ}$;

PG: preço da gasolina ao consumidor final (Cr\$/litro);

$a_{i}$ : relação entre elementos de receita do Governo com álcool anidro e PG ( $i=1$ : preço na refinaria; $i=2$ : tributos diretos na produção, distribuição e revenda); 
$b_{j}$ : relacão entre elementos de despesa do Govemo com álcool anidro e PG $(j=1$ : preco ao produtor na condição PVU ou PVD; $j=2$ : subsídio de equalização de custos; $j=3$ : encargos de mistura à gasolina);

$h_{i}$ : relação entre elementos de receita do Governo com álcool hidratado e PG ( $i=1$ : preço na refinaria; $1=2$ : tributos diretos na produção, distribuição e revenda);

$g_{j}=$ relação entre elementos de despesa do Governo com álcool hidratado e PG ( $f=1$ : preço ao produtor na condição PVU ou PVD; $j=2$ : subsidio de equalização de custos);

CTE: custos anuais de transporte e estocagem ( $\left.\operatorname{Cr} \$ 10^{\circ}\right)$.

Os custos de transporte e estocagem foram colocados à disposição, pela PETROBRÁs, de forma agregada, não sendo possivel separar os valores referentes ao anidro e ao hidratado. Por outro lado, os valores de $a_{i}, b_{j}, h_{i}$ e $g_{j}$ não sofrem variacões bruscas no curto prazo, salvo. quando ocorrem mudanças determinadas por politicas economicas do Governo (ex.: alteraça de alíquotas de tributos). Desta forma, justifica-se a formulação da eq.(14) pelo fato de uma estimativa grosseira do saldo do Governo ser possível rapidamente, principalmente se a estimativa excluir custos de transporte e estocagem.

A expressão (14) pode ser usada para projeções em cenários, desde que se tenha estimado os valores de $\mathbf{C H}$ e CA a partix das funcõos $\mathbf{D}$ e $\mathbf{z}$ atribuindo-se valores às variáveis envolvidas.

Propōe-se o seguinte procedimento: (a) obter os valores das variáveis (ou coeficientes) a partir das series históricas de dados e verificar, por inspeção, sua evolução; (b) tomar como referéncia os valores encontrados para os três anos mais recentes en que haja dados disponiveis; (c) avaliar o impacto, nos coeficientes ou variáveis, 
de alteraçōes em fatores que os afetem ou utilizar estimativas disponíveis; (d) atribuir, "Intuitivamente" ( $V$. item 4.7), valores a.os coeficientes e às variáveis das funções, para efeito de simulação.

Desta forma, a metodologia proposta comporta interação entre os procedimentos e os dados levantados.

\subsection{Procedimentos especificos}

\subsubsection{Período de análise}

Admitindo como relevante o fato de que a comercialização de álcool carburante só passou a se tornar polemica, no que se refere ao saldo do Governo, com a entrada no mercado do álcool hidratado, o período ideal básico de análise devería iniciar-se em 1980. Para este ano, porém, não há controles confiáveis sobre consumo aparente de álcool hidratado. Desta forma, propõe-se analisar o periodo 1981-90. Entretanto, para efeito de estimativa da demanda total de combustiveis para transporte e de seu fracionamento entre diesel e otto, com o intuito de captar todo o periodo desde o primeiro "choque do petróleo" que, como é público e notório, influiu nos hábitos de consumo e na politica de precos dos combustiveis, procurar-se-á utilizar dados a partir de 1973, o que, Inclusive, aumenta os graus de liberdade dos ajustamentos estatisticos. Este ano (1973) será considerado como base para as variáveis PIB e preço médio de combustiveis $\left[V . Y_{0}\right.$ e $\mathrm{PM}_{0}$ nas eq. (4) e (5)].

\subsubsection{Dados necessários}

Para a região Centro-Sul, os preços ao produtor de cana-de-açúcar e de álcool, assim como os subsidios de equalização de custos, apresentaram valores 
diferenciados para alguns Estados, durante o período em análise. O mesmo acontece para o ICMS dos Estados de São Paulo, Minas Gerais, Bahia, Sergipe e do Centro-Oeste. Oe valores médios serão obtidos através de ponderação pelas respectivas produçōes anuais no total de cada região.

Preços nas fases de produção, distribuição e revenda, encargos, tributos e subsídios serão ponderados, mês a mês, pelo número de dias de vigência de cada estrutura de preços respectiva, pressupondo-se distribuição uniforme em todos os dias do mês e desprezando-se a influência de domingos, feriados e similares.

Os valores médios anuais dos itens mencionados no parágrafo anterior serão obtidos mediante ponderação pelas quantidades de álcool entregues pelas destilarias para fins carburantes (consumo aparente).

Todos os valores monetários serão corrigidos para dezembro de 1990 pelo IGP-DI - Indice Geral de Preços - Disponibilidade Interna - publicado pela FGV/IBRE. A escolha desse indice, entre diversos outros disponiveis, justifica-se pela tradição em seu uso e pelo fato de ser praticamente o único, dos já utilizados para medir oficialmente o nivel de inflação, que apresenta série temporal ininterrupta durante todo o periodo de análise ${ }^{11}$.

\subsubsection{Tributos sobre a matérta-prima}

\section{a) Funrural}

Para se obter o montante desse tributo

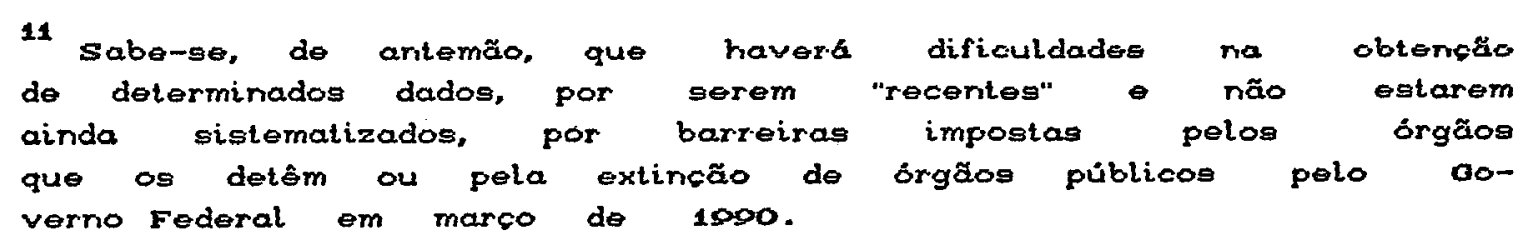


devido pela cana utilizada na fabricação de álcool carburante será utilizado um procedimento indireto, visto que não há controles confiáveis que permitam quantificar com precisão os rendimentos industriais especiflcos para 0 caso. Assim, tomando-se os preços oficiais da cana-deaçúcar (por região) e do álcool carburante (por tipo e região), e fazendo:

PC: Preco da cana no campo ( $\mathrm{Cr} \$ / t$ );

TR: Valor oficial do transporte da cana ( $\mathrm{Cr} \$ / \mathrm{t})$;

PE: Preço da cana na esteira ( $\mathrm{Cr} \$ / t$ );

TD: Tributos diferidos incidentes sobre a cana ( $\mathrm{Cr} \$ / t)$ :

$$
\mathrm{TD}=\mathrm{PE}-(\mathrm{PC}+\mathrm{TR})
$$

VP: Valor de paridade do álcool $\left(\mathrm{Cr} \$ / \mathrm{m}^{3}\right)$;

PP: Preço de paridade do álcool ( $\left.\mathrm{Cr} \$ / \mathrm{m}^{3}\right)$;

TM: Tributos incidentes sobre o álcool, devidos pela matéria-prima e diferidos $\left(\mathrm{Cr} \$ / \mathrm{m}^{3}\right)$ :

$$
T M=P P-V P ;
$$

C: Exigência de matéria-prima $\left(t / \mathrm{m}^{3}\right)$ :

$$
\mathrm{C}=\mathrm{TM} \cdot \mathrm{TD}^{-\mathbf{1}}
$$

VB: Valor base da cana para o Funrural ( $\mathrm{Cr} \$ / \mathrm{t})$;

F: Valor devido ao Funrural $\left(\mathrm{Cr} \$ / \mathrm{m}^{3}\right)$ :

$$
F=0,025 \cdot \mathrm{C} \cdot \mathrm{VB}
$$

Até 28/01/81, não aparece o valor do ICM nas estruturas de preços da cana-de-açúcar para a região Centro-Sul; trata-se de mera questão aritmética a ser considerada nos cálculos. Quanto ao valor base da tonelada de cana para aplicação da alíquota do Funrural, ver item 4.3.

Está-se adotando como principio que a comercialização da cana-de-açucar só ocorre en função da 
realização de produtos. Portanto, os recureos devidos ao Funrural pela matéria-prima correspondente serão considerados como gerados pelo álcool produzido.

\section{b) Tributos diferidos}

Referem-se a PIS, Finsocial e ICM (atualmente ICMS) que incidem sobre a cana, mas que são diferidos para o momento da comercializaça dos produtos. Correspondem, nas estruturas de precos, às diferencas entre os precoe de paridade e os valores de paridade respectivos (exemplo no Apêndice 1).

No caso do ICM (atualmente, ICMS), serão consideradas apenas as operaçöes internas nos Estados. Para operaçóes interestaduais há aliquotas diferenciadas, mas não serão consideradas neste estudo, dada a evidencia de que as quantidades de cana comercializadas nessas circunstâncias são insignificantes.

A Constituição da República Federativa do Brasil (1988) contém dispositivos que permitem alterar aliquotas de tributos existentes, bem como a criação de outros. Assim, a aliquota do Finsocial passou a ser de $1,2 \%$ a partir de 1989, e de $2 \%$ a partir de abril de 1991.

Um novo tributo é o IVV, de alcada dos municipios. Pelas Disposiçōes Transitórias da Constituição Federal, a aliquota máxima e de $3 \%$ sobre o preco de venda ao consumidor final. Neste trabalho, vai-se admitir que todos os municipios do pais estarão cobrando esse imposto, a partir de 1989, pela alíquota máxima. 


\section{6. 4 Outros tributos}

\section{a) Sobre o faturamento da destilaria}

Compõem-se de PIS e Finsocial e incidem sobre os preços ao produtor na condicäo PVU ou PVD. De modo prático, correspondem às diferencas entre os preços de faturamento e os preços de paridade (V. Apêndice 1, como exemplo). Também neste caso, a alíquota do Finsocial passa de $0,5 \%$ para $1,2 \%$ do faturamento, a partir de 1989 , e para $2 \%$ a partir de abril de 1991.

\section{b) Sobre distribuição e revenda}

Correspondem ao Finsocial incidente sobre o faturamento das distribuidoras e dos postos de revenda, respectivamente; alíquotas de $0,5 \%$ até 1988 , de $1,2 \%$ a partir de 1989 e de 2\% a partir de abril de 1991.

$\mathrm{Na}$ etapa de revenda, os tributos correspondem à aplicação da alíquota do Finsocial sobre o faturamento dos postos de servicos. Na fase de distribuição, aplicam-se as mesmas alíquotas sobre o preço de faturamento das distribuidoras (precos aos postos de revenda).

\section{6. 5. Subsidios de equalizaço de custos}

Têm a função teórica básica de compensar, para os produtores, diferencas regionais de rendimentos e custos de produção ou aquisição da matéria-prima. No caso do álcool, é devido ao produto fabricado diretamente do caldo de cana fermentado, isto é, não se aplica ao produto obtido do mel residual da fabricação do açúcar (álcool residual). Faziam jus a esse beneficio todos os produtores 
do Norte-Nordeste, e no Centro-Sul, os do Estado do Rio de Janeiro, com a ressalva de que já houve época em que os produtores do Espírito Santo e de Minas Gerais também foram contemplados.

A partir de $07 / 11 / 90$, os valores dos subsidios não mais aparecem nos documentos oficiais que estabelecem pregos para o setor sucroalcooleiro. Entretanto, concomitantemente mudou-se o criterio de fixação dos valores de paridade do álcool. A partir daquela data, o álcool da região Norte-Nordeste passou a ter seus valores de paridade fixados em valores cerca de $25 \%$ acima dos referentes ao Estado de São Paulo, e o do Rio de Janeiro, cerca de $8,4 \%$ acima. Esta nova situação não altera as despesas do Governo na aquisição de álcool dos produtores, mas os tributos (receitas) passam a incidir sobre valores maiores de preços de paridade e de aquisição ao produtor na condição PVU ou PVD.

\subsubsection{Custos de transporte e armazenagem}

Os custos de transporte e armazenagem do álcool carburante são cobertos pelo Governo. No caso do transporte, os custos são ressarcidos às distribuidoras com base em planilha do CNP (atual DNC) em função das distâncias percorridas. 0 álcool anidro é carreado das destilarias para os centros de mistura. 0 hidratado pode ser levado para centros de captação ou, mais frequentemente, retirado diretamente das destilarias pelas distribuidoras, que são pagas com base na planilha mencionada.

De acordo com CosTA (1983), em palestra proferida em abril de 1983, o custo do frete do alcool hidratado era de $\mathrm{Cr} \$ 0,7116$ por litro, para um preço ao consumidor de $\operatorname{Cr} \$ 123,00$, o que permite calcular que 0 frete representava $0,54 \%$ do preço final. Para o anidro, os 
valores eram de $\operatorname{Cr} \$ 1,3805, \operatorname{Cr} \$ 210,00$ e $0,66 \%$, respectivamente.

Entretanto, informação da PETROBRÁS (s.d.) dá conta que, do prego final da gasolina, $2 \%$ são destinados a cobrir as despesas de transporte com o objetivo de manter preços uniformes em todo o território nacional.

Os dois parágrafos anteriores têm o propósito único de ilustrar a discrepância de informações dentro da própria empresa estatal. Neste trabalho, serão utilizados os dados contábeis gentilmente fornecidos ao autor pela PETROBRÁS, em que estão registrados os custos de transporte e armazenagem, Incluindo perdas (V. Apêndice 13), de onde os eventuais interessados podem facilmente calcular a participação dos custos em questão nos custos totais da comercialização do álcool carburante.

\section{7. Cenários}

Em trabalho do MIC/STI (1984), lançou-se mão do uso de cenários com o intuito de se desenvolver estudo sobre previsão e análise tecnológica do PROÁLCOOL. Segundo - mesmo, cenários facilitam "[...] o estudo exploratório de uma situação futura onde os fatores considerados são projetados de forma a manter a consistência entre si. Uma vez que o futuro é imprevisivel, a utilização de cenários alternativos permite a comparação entre possibilidades futuras.

Os cenários são construídos por meio de extrapolações de tendências históricas, ajustando os coeficientes conforme objetivos explícitos e problemas percebidos, bem como por melo de métodos intuitivos [...]."

No trabalho em questão, o último dos procedimentos mencionados no parágrafo anterior - métodos intuitivos - refere-se às técnicas conhecidas como painel 
de especialistas e Delphi, técnicas estas que não será viável utilizar neste estudo, tendo em vista os custoe que seriam envolvidos, o tempo necessário e a finalidade do trabalho. Entretanto, será preservado o caráter intuitivo no estabelecimento de valores de variáveis e coeficientes, controlado, porém, por observaçóes de seu comportamento histórico e por cálculos ou estimativas disponiveis des projecões dos dados em questão.

Os cenários a serem construidos neste trabalho seräo do tipo extrapolativo, adequado para o curto prazo, levando-se em consideração modificaçōes “atuais" em fatores intervenientes, mas sem o rigor metodolófico necessário à montagem de cenários transitivos.

É comum encontrar-se, em trabalhos dessa natureza, a construção de três cenários: otimista, intermediário (ou "mais provável") e pessimsta. A definição de cenário otimista - e, por analogia, de cenárlo pessimista - é intuitiva: é o que contém a ocorrência de eventos "favoráveis", à sociedade ou ao objeto de análize. No caso presente, considerar-se-ão positivos para o cenário, por exemplo, maior PIB, menores precos ao produtor de álcool carburante, maior carga tributária sobre os combustiveis, e assim por diante.

A partir deste ponto, o desenvolvimento completo da metodologia envolve interaça com os dados levantados, visando embasar as proposicooes a serem feitas.

\subsubsection{Produto Interno Bruto}

A politica econômica em vigor desde 1990, caracterizada por desestimulo ao consumo e a atividade produtiva, levou à estagnação do crescimento econômico do pais, inclusive com queda do PIB em 1990. As perspectivas são de crescimento a partir de 1992 ou 1993, segundo 
análises de especialistas e pronunciamentos do próprio governo divulgados pelos meios de comunicação. Na revista Suma Econômica (1991), encontram-se projeçōes do PIB para o periodo 1991-95 (Tabela 1), cada ano em relaçäo ao ano anterior.

Tabela 1. Estimativa de evolução do PIB (\% em relação ao ano anterior.

\begin{tabular}{cccc}
\hline Ano & Otimista & Intermediário & Pessimista \\
\hline 1991 & 6,0 & 3,5 & $-2,0$ \\
1992 & 6,5 & 4,5 & 1,5 \\
1993 & 8,0 & 4,9 & 2,3 \\
1994 & 7,0 & 5,7 & 2,6 \\
1995 & 8,0 & 6,0 & 2,6 \\
\hline
\end{tabular}

FONTE: Suma Econômica (1991).

\subsubsection{Precos médios dos combustí veis ao consumidor}

A posição defendida pelos órgãos gestores da política energética é que há defasagem pronunciada de preços dos combustiveis, havendo pressão desses organismos por aumentos reais. No cenário otimista, propõe-se que, ao final do período 1991-95, os precos médios tenham recuperado o nivel de 1981 (ao redor de 100\% de crescimento real em relação a 1990); no intermediário, os precos voltariam aos niveis de 1985 ( $52 \%$ de acréscimo) e, no pessimista, haveria uma recuperação de apenas $20 \% \mathrm{em}$ relaçao aos niveis de 1990 . Na Tabela 2 estão anotadas as evoluções propostas para os preços médios (V. também o Apêndice 11).

Com a previsão de a recessão econômica continuar em 1991, ao lado de taxas inflacionárias relativamente elevadas, supõe-se, neste caso, a recuperação dos pregos se de em ritmo pouco acentuado, ficando os reajustes 
mais "pesados" para o biênio 1992-93, dai por diante apenae se completando o reajuste total proposto.

Tabela 2. Projeção da evolução dos preços médios ao consumidor final dos combustiveis para transportes (\% em relação ao ano anterior).

\begin{tabular}{cccc}
\hline Ano & Otimista & Intermediário & Pessimista \\
\hline 1991 & 10 & 5 & 3 \\
1992 & 25 & 15 & 3 \\
1993 & 25 & 10 & 5 \\
1994 & 10 & 8 & 5 \\
1995 & 6 & 6 & 3 \\
\hline
\end{tabular}

FONTE: Estimativas do autor.

\subsection{Precos relativos otto/diesel}

Sabendo-se, por definição adotada neste trabalho, que o preço médio dos combustíveis (PM) é a média aritmética dos precos ao consumidor do diesel (PD*), da gasolina (PG*) e do álcool hidratado (PH*); que o preco médio dos combustiveis ciclo otto é a média aritmética dos preços ao consumidor da gasolina e do álcool hidratado (todos os precos em $\mathrm{Cr} \$ / \mathrm{tEP}$ ), chega-se à seguinte relaçáo ${ }^{12}$, onde $\mathrm{PR}$ é o preco relativo otto/diesel e $t$ um dado ano:

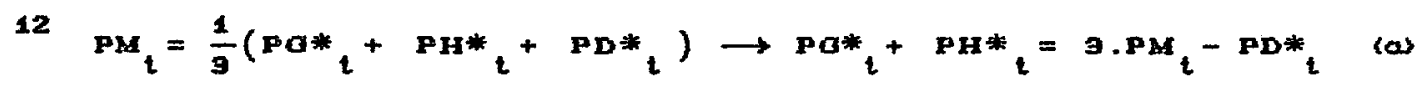

$$
\begin{aligned}
& P R_{t}=\frac{1}{P D}\left(\frac{P Q *_{t}+P H *_{t}}{2}\right) \rightarrow P Q *_{t}+P H *_{t}=2 P R_{t} \cdot P D *_{t} \quad(b)
\end{aligned}
$$

I gualando $\langle a\rangle=\langle b\rangle$ :

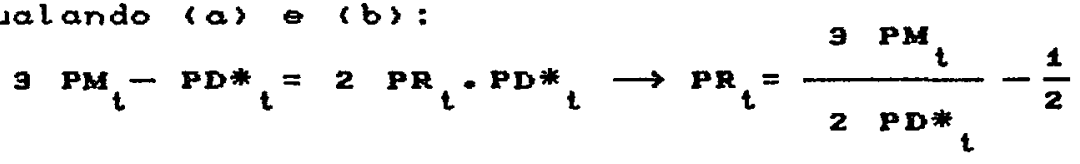




$$
\mathrm{PR}_{\mathrm{t}}=\frac{3 \mathrm{PM}_{\mathrm{t}}}{2 \mathrm{PD*} *_{\mathrm{t}}}-\frac{1}{2}
$$

Tomando-se $k$ e $x$ como as variaçōes, num dado ano $t$ em relação ao ano anterior, do preco médio dos combustiveis e do preco do diesel, respectivamente, tem-se:

$$
\mathrm{PR}_{t}=\frac{3(1+k) \mathrm{PM}_{t-1}}{2(1+\mathrm{x}) \mathrm{PD}_{t-1}}-\frac{1}{2}
$$

No desenvolvimento aqui utilizado, OQB valores de $k$ estão pré-estabelecidos e os valores de $\mathrm{PM}_{\mathrm{Li}}$ e $\mathrm{PD}_{t-1}$ são conhecidos para o primeiro ano do período 1991-95 ou podem ser calculados sequencialmente para os anos subsequentes. Desta forma, o preço relativo no ano $t$ passa a ser função da variação do preço do diesel $(x)$ no mesmo ano em relacão ao ano anterior.

Os pregos do óleo diesel têm forte impacto no resultado de políticas econômicas especificas, visto ser - combustivel predominante no transporte coletivo de passageiros e de carga. Em atenção a esta característica, têm sido sistematicamente mantidos abaixo dos precos médios dos outros combustiveis. Partindo-se do pressuposto que haverá aumento dos precos médios dos combuetivels (Tabela 2), propõe-se a evolução dos preços do diesel tomando-se como base as seguintes referências em relação aos dados da Tabela 2: a) no cenário otimista, variação anual do preço do diesel correspondente a $90 \%$ da variação do preço médio $(x=0,9 k)$; b) no cenário intermediário, variação do preço do diesel igual à variação do preço médio $(x=k)$, ou seja, mantendose constante o preço relativo; c) no cenário pessimista, variação do preço do diesel correspondente a $110 \%$ do preço médio $(x=1,1 k)$. 
43.

Essas projecöes, de caráter indicativo, tomam como base o pressuposto que, no cenário otimista, taxas de reajuste dos combustiveis mais elevadas permitiriam continuar "beneficiando" o diesel com reajustes menores que os demais combustiveis, sem comprometer o equilibrio financeiro do sistema. Em oposição, no cenário pessimista, dado que a recomposição de precos é sensivelmente menor, os consumidores do diesel seriam chamados a arcar com taxas de reajustes relativamente maiores. Com essas premissas, pode-se calcular, pela eq.(15), os dados constantes da Tabela 3.

Tabela 3. Projeção das relaçöes de precos entre combustiveis ciclo otto e diesel.

\begin{tabular}{lccc}
\hline Ano & Otimista & Intermediário & Pessimista \\
\hline 1991 & 2,468 & 2,441 & 2,432 \\
1992 & 2,528 & 2,441 & 2,423 \\
1993 & 2,590 & 2,441 & 2,410 \\
1994 & 2,618 & 2,441 & 2,396 \\
1995 & 2,636 & 2,441 & 2,388 \\
\hline
\end{tabular}

FONTE: Estimativas do autor.

\subsection{Coeficientes de transformação em tEP}

Pelos dados do Apêndice 9, verifica-se que os coeficientes de transformação em teP de medidas em volume $\left(t E P / m^{3}\right)$ são constantes para o álcool anidro $(\mathrm{ca}=0,520)$ e para o álcool hidratado $(\mathrm{ch}=0,496)$. No caso da gasolina, o coeficiente em questäo variou, no periodo 1985-89, entre 0,767 e 0,773. Como este coeficiente depende da qualidade da matéria-prima (petróleo) e do sistema de fracionamento, admitir-se-á que o mesmo será constante no periodo $1991-95$ e igual a 0,773 . 
Portanto, propõe-se admitir que os três coeficientes - para anidro, hidratado e gasolina - serão constantes no período adotado para as projeçoes deste estudo.

\subsubsection{Taxa de mistura de álcool anidro à gasolina}

A fração volumétrica de álcool anidro na mistura com gasolina tem seu limite superior estabelecido tecnicamente em $25 \%$, segundo MIC/STI (1985). Na determinação oficial da percentagem na mistura, é usual uma tolerância de $1 \%$, para mais ou para menos, o que leva a uma fração máxima teórica de $24 \%$ a ser estabelecida oficialmente. Convencionou-se fixar em $22 \%$ a taxa “ideal" de mistura, inclusive sob o argumento de que taxas sienificativamente menores agravam os problemas de poluição atmosférica nas grandes cidades pelo aumento na emissão de gases indesejáveis por veículos automotores a gasolina.

No Apêndice 10 estão anotados os valores observados no período 1973-90. Verifica-se que, de 1983 a 1988, a participação do álcool anidro na mistura com gasolina manteve-se muito próxima da taxa ideal. No primeiro semestre de 1989 ocorreu escassez de álcool, levando o Governo a determinar redução na percentagem de mistura, fazendo com que a taxa anual média caises para pouco mais de 16\%. Em 1990 ocorreu situaça semelhante e em maior intensidade, caindo a taxa para cerca de $11,5 \%$. Ressalte-se que nesses anos parte da demanda foi atendida por produtos importados, principalmente o metanol. Entretanto, os dados sobre os volumes consumidos desse produto não constam sequer das estatisticas oflciais sobre consumo de energia para transportes (Balanco Energético Nacional), provavelmente englobados na rubrica "Outros".

Dados extraoficials indicam que a capacidade instalada de produção de álcool no Brasil gira em torno de 
16 bilhões de litros por safra, com as produçoes tendo se mantido ao redor de 13 bilhões de litros, incluindo outros usos. Aceitos esses dados, haveria capacidade ociosa na Indústria alcooleira, capaz de atender eventuais decisões empresarials de aumentar a producäo, o que, en tese, dependeria da elevação dos preços ao produtor. Enquanto continuar havendo a intervenção governamental no setor, essa ocorrência não será ditada apenas pelas chamadas forcas de mercado.

A quantidade e complexidade de fatores envolvidos tornam impraticável qualquer projeção segura dos valores em questão, fazendo com que este procedimento tenha caráter indicativo, tomando-se como base a seguinte perspectiva: no cenário otimista, espera-se que que se reduza o consumo de álcool hidratado, liberando capacidade de producão para o álcool anidro e permitindo adotar taxas de mistura à gasolina iguais às recomendadas . Ao contrário, no cenário pessimista espera-se aumento da demanda por álcool hidratado, o que, de per si, já dificultaria o aumento do volume de anidro na mistura com a gasolina, em função da limitacão na capacidade de produção, eliminada a hipótese de novos investimentos na ampliacão do parque alcooleiro.

As taxas propostas de mistura de álcool anidro à gasolina estão anotadas na Tabela 4 .

Tabela 4. Projeções de taxas de mistura de álcool anidro à gasolina (\% de AEAC no volume total).

\begin{tabular}{lccc}
\hline Ano & Otimista & Intermediário & Pessimista \\
\hline 1991 & 15 & 12 & 10 \\
1992 & 18 & 14 & 10 \\
1993 & 22 & 16 & 12 \\
1994 & 22 & 16 & 12 \\
1995 & 22 & 15 & 10 \\
\hline
\end{tabular}

FONTE: Estimativas do autor. 
4.7.6. Precos da gasolina ao consumidor final

Sendo PG* o preco da gasolina por unidade energética ( $\mathrm{Cr} \$ 1000 /$ tEP); PG o preco em volume ( $\mathrm{Cr} \$ /$ litro); cg e ca os coeficientes $\left(t E P / \mathrm{m}^{3}\right)$ de gasolina "pura" e álcool anidro, respectivamente; m a fração volumétrica de álcool anidro na mistura com gasolina, pode-se escrever:

$$
\mathrm{PG}=[(1-\mathrm{m}) \mathrm{cg}+\mathrm{m} \cdot \mathrm{ca}] \mathrm{PG} *
$$

onde a expressão entre colchetes dá o coeficiente $\left(\mathrm{tEP} / \mathrm{m}^{3}\right)$ da mistura "gasolina + anidro".

Tomando-se y como a relação entre os preços ao consumidor (em tEP) do álcool hidratado e da gasolina, $r$ a mesma relação de pregos en volume e ch o coeficiente $\left(\mathrm{tEP} / \mathrm{m}^{3}\right)$ do álcool hidratado, vem que ${ }^{\mathbf{3}}$ :

$$
y=r \frac{(1-m) c g+m \cdot c a}{c h}
$$

Pelos dados dos Apêndices 15 e 16, pode-se calcular que, no período 1988-90, os valores de $r$ foram, em Bequência: 0,$700 ; 0,810$ e 0,754 . Propõe-se admitir como sendo de $0,85,0,75$ e 0,65 as relações mencionadas, constantes para o perfodo 1991-95, respectivamente nos cenários otimista, intermediário e pessimista.

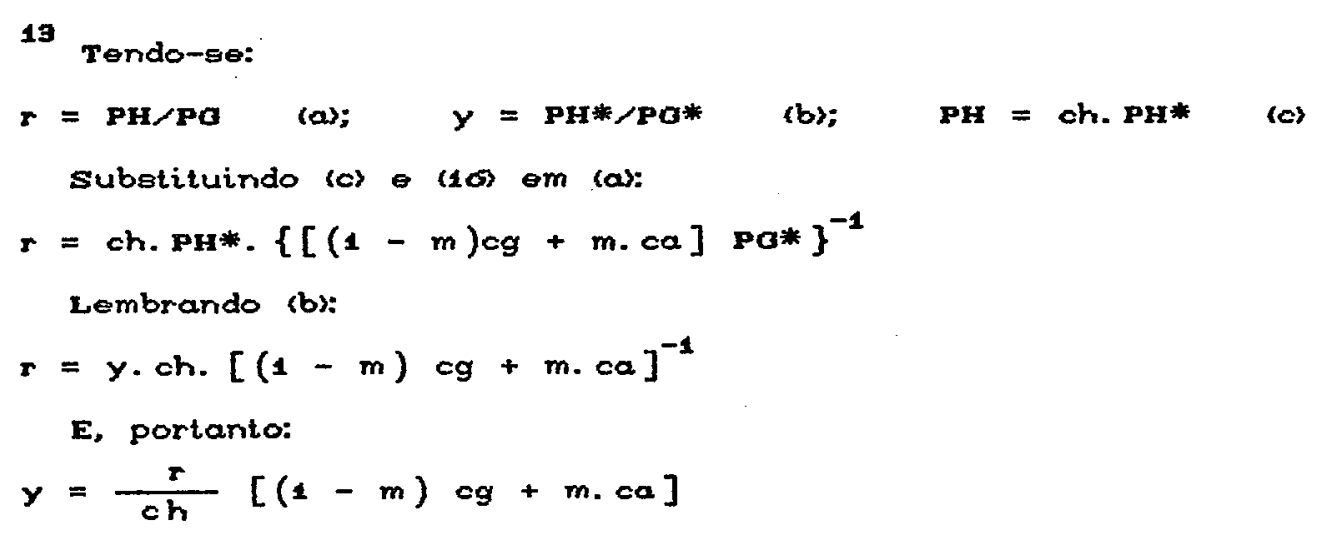


Por outro lado, lembrando a definição de preço médio (PM) adotada neste trabalho, chega-ee à seguinte expressão ${ }^{14}$ :

$$
\mathrm{PG} *=\frac{3 \mathrm{PM}-\mathrm{PD} *}{1+\mathrm{y}}
$$

onde PD* é o preço do óleo diesel ao consumidor final (Cr\$ 1000/tEP).

Considera-se pré-estabelecidos os valores dé PM (item 4.7.2), de PD* (item 4.7.3), de cg, ca e ch (item 4.7.4) e de $m$ (item 4.7.5). Desta maneira, conjugando-se as expressões (16), (17) e (18) chega-se às projeçōes do preço da gasolina ao consumidor final constantes da Tabela 5.

Tabela 5. Projeções do preço da gasolina ao consumidor final ( $\mathrm{Cr} \$ /$ litro, valores de dez.90).

\begin{tabular}{lccc}
\hline Ano & Otimista & Intermediário & Pessimista \\
\hline 1991 & 78,22 & 80,14 & 84,82 \\
1992 & 97,72 & 91,86 & 87,32 \\
1993 & 121,86 & 100,72 & 91,28 \\
1994 & 134,29 & 108,79 & 95,75 \\
1995 & 142,50 & 115,50 & 98,90 \\
\hline
\end{tabular}

FONTE: Estimativas do autor.

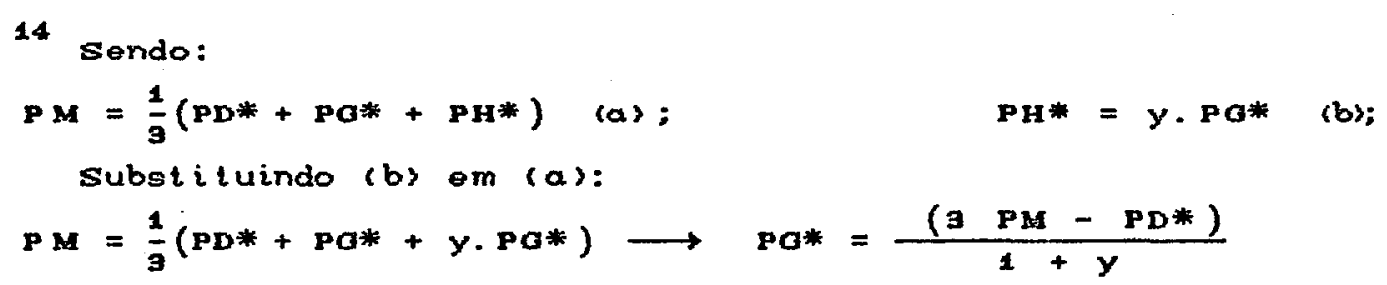


4.7.7. Relaçôes entre elementos de receita e elementos de despesa do Governo e o preco da gasolina

Uma projeção mais segura das relações deste item exigiria o pré-estabelecimento de todos os valores dos elementos de receita e elementos de despesa do Governo na comercialização do álcool carburante. Propõe-se, em lugar desse procedimento, o estabelecimento intuitivo dos valores de $\left(\Sigma a_{i}-\Sigma b_{j}\right)$ e $\left(\Sigma h_{i}-\Sigma g_{j}\right)$, conforme tabelas $6 A$ e $6 B$. No cenário otimista, o escopo poderia ser conseguido via aumento da tributação sobre os combustiveis e pelo repasse menos que proporcional aos produtores de álcool dos aumentos praticados. No cenário pessimista, supōe-se redução da carga tributária, o que, aliás, viria ao encontro a uma pressão atual da sociedade brasileira. Obviamente, os valores propostos carecem de fundamentação metodológica mais rigorosa e devem ser encarados como sendo de natureza indicativa para eventuais medidas de politica econômica. Os valores observados no período 1981-90, bem como o significado dos simbolos, estäo no Apêndice 17.

Tabela 6A. Projeção das relaçöes entre elementos de receita e elementos de despesa do Governo na comercialização de álcool carburante e o preco da gabolina ao consumidor final. Álcool anidro (valores de $\left.\Sigma a_{i}-\Sigma b_{j}\right)$.

\begin{tabular}{lccc}
\hline Ano & Otimista & Intermediário & Pessimista \\
\hline 1991 & 0,42 & 0,42 & 0,40 \\
1992 & 0,45 & 0,43 & 0,39 \\
1993 & 0,50 & 0,45 & 0,38 \\
1994 & 0,55 & 0,45 & 0,38 \\
1995 & 0,55 & 0,45 & 0,38 \\
\hline
\end{tabular}

FONTE: Estimativas do autor. 
Tabela 6B. Projeção das relações entre elementos de receita e elementos de despesa do Governo na comercialização de álcool carburante e o preço da gasolina ao consumidor final. Álcool hidratado (valores de $\left.\Sigma h_{i}-\Sigma g_{j}\right)$.

\begin{tabular}{cccc}
\hline Ano & Otimista & Intermediário & Pessimista \\
\hline 1991 & 0,05 & 0,00 & 0,00 \\
1992 & 0,10 & 0,00 & $-0,01$ \\
1993 & 0,15 & 0,00 & $-0,05$ \\
1994 & 0,18 & 0,00 & $-0,08$ \\
1995 & 0,20 & 0,00 & $-0,10$ \\
\hline
\end{tabular}

FONTE: Estimativas do autor.

4.7.8. Projecóes da frota e do consumo medio de veículos a álcool

Os dados do Apêndice 14 mostram que, a partir de 1988, o número de veículos a álcool vendidos no mercado interno vem declinando de forma acentuada. Presume-se que, mesmo que haja um certo aquecimento nas vendas desses modelos, não se atingirão os níveis do período 1983-88. A depender da relação de preços ao consumidor do álcool hidratado e da gasolina e da recomposição do poder de compra da população, mesmo essa perspectiva - aquecimento das vendas de veículos a álcool poderá não se concretizar.

De modo totalmente intuitivo, propöe-se a seguinte projeção da frota de álcool para o período 1991-95, em relação a 1990: a) cenário otimista (preco do álcool hidratado igual a $85 \%$ do preço da gasolina): redução da frota a álcool à base de $5 \%$ ao ano; b) cenário intermediário (relação de preços: 75\%): manutenção da frota 
atual, com os veiculos novos apenas repondo os sucateados; c) cenário pessimista (relação de preços: 65\%): aumento da frota a álcool a uma taxa de $5 \%$ ao ano.

Quanto ao consumo médio $\left(\mathrm{m}^{3}\right.$ por veículo por ano), propõe-se as seguintes projeções para o período 1991-95: a) cenário otimista: redução do consumo médio à base de $5 \%$ ao ano; b) cenário intermediário: manutenção do consumo anual médio igual ao de $1990\left(2,42 \mathrm{~m}^{3}\right.$ por veículo); c) cenário pessimista: crescimento do consumo médio, em relação a 1990 , à base de $5 \%$ ao ano.

\subsubsection{Projeçóes dos custos de transporte e armaze- nagem do álcool carburante}

Com os dados que foi possivel obter ( $V$. Apêndices 13 e 18), não dá para se relacionar os custos de transporte e armazenagem com quaisquer outros dados disponiveis (consumo aparente, precos, etc.). Desta forma, seria temerário qualquer tipo de ilação a respeito. Assim, fica uma lacuna na metodologia proposta até este ponto. De qualquer modo, enfatizando-se essa ressalva, propōe-se como projeção para o período 1991-95 uma variação, em relação a 1990, nos custos de transporte e armazenagem as mesmas taxas adotadas para os precos do bleo diesel (V. item $4.7 .3)$.

No próximo capitulo, calculam-se os saldos do Governo no periodo 1981-90, estimam-se e selecionam-se funcões de demanda total por combustiveis e de relação entre demandas por diesel e ciclo otto e calculam-ee os saldos do Governo projetados em três cenários alternativos, com base nas equações e projeções apresentadas neste capitulo. 


\section{Resultados e Dicussão}

O ajustamento das funções (4) a (7); de acordo com o procedimento descrito no item 4.5, resultou nas estimativas anotadas na Tabela 7 .

Tabela 7. Ajustamento estatístico das funções de demanda total por combustiveis e de relação entre demandas por diesel e ciclo otto.

\begin{tabular}{|c|c|c|c|c|c|}
\hline Função & 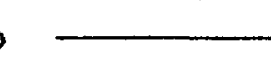 & Estimativas & dos parâme & $\operatorname{ros}$ & SQRes \\
\hline (4) & $\begin{array}{c}\hat{\alpha}_{0} \\
4,000\end{array}$ & $\begin{array}{c}\hat{a_{1}} \\
4,308\end{array}$ & $\begin{array}{c}\hat{a}_{2} \\
14,054\end{array}$ & & \\
\hline & $(0,255)$ & $(0,765)$ & $(2,475) * *$ & & 13,385 \\
\hline (5) & $\begin{array}{c}\hat{\beta}_{0} \\
1,043\end{array}$ & $\begin{array}{c}\hat{\beta}_{1} \\
6,182\end{array}$ & $\begin{array}{c}\beta_{2} \\
13,176\end{array}$ & $\begin{array}{r}\beta_{9} \\
-4,725\end{array}$ & \\
\hline & $(0,125)$ & $(2,072) *$ & $(5,251) * * *$ & $(6,991) * * *$ & 3,282 \\
\hline & $\hat{\gamma}_{0}$ & $\gamma_{1}$ & $\gamma_{2}$ & & \\
\hline (6) & $e^{-0,190}$ & 0,715 & 0,241 & - & \\
\hline & $(0,988)$ & $(3,954) * * *$ & $(2,108) *$ & & 0,058 \\
\hline (7) & $\begin{array}{c}\hat{\delta}_{0} \\
0,919\end{array}$ & $\begin{array}{c}\hat{\delta}_{1} \\
0,626\end{array}$ & $\begin{array}{c}\hat{\delta}_{2} \\
0,218\end{array}$ & - & \\
\hline & $(4,615) * * *$ & $(2,738) * *$ & $(1,591)$ & & 0,078 \\
\hline
\end{tabular}

Obs. : Para cada função, a primeira linha corresponde aos Eímbolos dos parâmetros; a segunda linha, às estimativas dos parâmetros. Sob as estimativas dos parâmetros estão anotadas, entre parênteses, as estimativas do teste $t$ de Student; $* * *$ significativo a $1 \%$; ** significativo a $5 \%$; * significativo a $10 \%$. 
Pelos critérios estabelecidos de seleção entre funçōes alternativas (menor soma de quadrados do residuo), a função estimada de demanda total de combustiveis é a resultante do ajustamento da eq.(5), cujo enunciado fica:

$$
\hat{D}_{L}=1,043+6,182 \ln D_{i-1}+13,176 \ln \frac{Y_{L}}{Y_{0}}-4,725 \ln \frac{P M_{i}}{P M_{0}}
$$

0 significado da simbologia adotada encontra-se no item 4.5, em seguida aos modelos propostos.

Na Tabela 7 , verifica-se que, no teste de significância dos parâmetros - com base em valores estimados de $t_{i}$ da distibuição de student - resultou que o termo constante não é significativo até o nivel de $10 \%$ (desprezando-se niveis maiores). Para os demais coeficientes, 0 da varínel in $D_{t-1}$ resultou significativo a $10 \%$ e os das variáveis In $\left(\mathrm{Y}_{\mathrm{t}} / \mathrm{Y}_{0}\right)$ e $\ln \left(\mathrm{PM}_{\mathrm{t}} / \mathrm{PM}_{0}\right)$ mostraram-se significativos a $1 \%$.

Aplicando-se, por sua vez, o teste unilateral, pode-se vertficar que $\beta_{1}>0$ no nivel de significância de $5 \%$; que $\beta_{2}>0$ e que $\beta_{3}<0$, ambos a $1 \%$ de significância, conforme se esperava.

Para a função de relação entre demandas por combustiveis diesel e ciclo otto, o modelo que atende o critério de menor soma de quadrados do residuo é o da eq. (6), cuja função estimada é:

$$
\hat{z}_{t}=\exp (-0,136) \mathrm{z}_{t-1}^{c, 715} \mathrm{PR}_{\mathrm{t}}^{\mathrm{c}, 241}
$$

Neste caso, o termo constante não é 
signiflcativo até o nível de $10 \%$, o parâmetro da variável $\mathrm{Z}_{\mathrm{t}-1}$ é significativo a $1 \%$ e o da varível $\mathrm{PR}_{\mathrm{t}}$ gignificativo a $10 \%$. Pode-se também verificar que $\gamma_{1}>0$ e que $\gamma_{2}>0$, a $1 \%$ e $5 \%$ de significância, respectivamente.

Utilizando-se as informações, pressupostos e critérios adotados no cap. 4 e os dados dos apêndices 1 a 17, chegou-se, numa primeira etapa, aos saldos anuais do Governo no período 1981-90, anotadoe no Apêndice 18 e transcritos na Tabela 8.

Tabela 8 . Saldos anuais do Governo na comercialização de álcool carburante (1981-90).

\begin{tabular}{|c|c|c|c|c|c|c|c|}
\hline Ano & $\begin{array}{c}\mathrm{CA} \\
m i \mathrm{~m}^{3}\end{array}$ & $\Sigma a-\Sigma b$ & $\begin{array}{c}\mathrm{CH} \\
m i \iota m^{3}\end{array}$ & $\Sigma \mathbf{h}-\Sigma_{\mathbf{g}}$ & $\begin{array}{c}P G \\
C \times \$ / l\end{array}$ & $\begin{array}{c}\text { CTE } \\
\operatorname{cr} \$ 10^{\circ}\end{array}$ & $\begin{array}{l}\text { Saldo } \\
\operatorname{cr} \$ 10^{\circ}\end{array}$ \\
\hline 1981 & 1146,1 & 0,397 & 1767,4 & 0,048 & 177,28 & $*$ & 95,70 \\
\hline 1982 & 2020,9 & 0,360 & 1691,1 & 0,056 & 155,71 & $*$ & 128,03 \\
\hline 1983 & 2196,5 & 0,388 & 2814,5 & 0,055 & 144,42 & 7,21 & 138,23 \\
\hline 1984 & 2081,6 & 0,402 & 4462,3 & 0,061 & 135,84 & 17,70 & 132,95 \\
\hline 1985 & 2120,9 & 0,326 & 5654,3 & 0,070 & 122,33 & 108,68 & 24,32 \\
\hline 1986 & 2442,4 & 0,412 & 8225,9 & 0,063 & 113,15 & 80,06 & 92,44 \\
\hline 1987 & 2135,8 & 0,473 & 8773,1 & 0,055 & 138,85 & 61,84 & 145,43 \\
\hline 1988 & 1988,5 & 0,448 & 9644,0 & 0,064 & 170,71 & 75,65 & 181,79 \\
\hline 1989 & 1723,8 & 0,368 & 10880,0 & 0,006 & 76,97 & 29,82 & 24,03 \\
\hline 1990 & 1300,5 & 0,403 & 10205,1 & 0,001 & 74,08 & 15,76 & 23,82 \\
\hline
\end{tabular}

FONTE: Apêndice 18.

* Dados não disponiveis.

Obs.: $\mathrm{SG}=$ (A.CA + H.CH) PG - CTE, cf. eq. (14).

$\mathrm{CA}$ : consumo aparente de anidro; $\mathrm{CH}$ : consumo aparente de hidratado;PG: prego da gasolina ao consumidor final;CTE: custos de transporte e armazenagem de álcool carburante; $\Sigma$ : somatórios das relaçoes entre elementos de receita ou elementos de despesa do governo com o preco da gasolina (a: receitas do anidro; $b$ : despesas do anidro; $h$ : receltas do hidratado; g: despesas do hidratado); SG: saldo do Governo. 
54.

Em decorrência dos dados que foi possivel obter, para os anos de 1981 e 1982 não constam os custos de transporte e armazenagem; para 1983 e 1984, não constam os valores do transporte pagos pelo Governo às distribuidoras (V. Apêndice 13). Desta maneira, no período 1981-84 os saldos positivos observados estão sobreestimados.

No período 1985-90, os saldos foram sempre positivos e já considerados os custos completos de transporte e armazenagem. Nota-se que em 1989 e 1990 houve sensivel redução, em relação a 1988, nos valores estimados do saldo, possivelmente devido a queda geral dos precos dos combustiveis ( $V$. Apêndices 15 e 16).

Lembrando a eq.(B), que dá a demanda por combustiveis ciclo otto ( $D O$ ) em função de $\mathrm{D}$ e $\mathrm{Z}$, a partir de (19) e (20), com as projecóes de dados das tabelas 1 a 6B, e utilizando-se, em sequência, (12), (13) e (14), chega-se aos saldos estimados do Governo para o período 1991-95, nos cenários otimista, intermediário e pessimista (V. apêndices 19,20 e 21 ). Os dados resultantes estão na Tabela 9.

Tabela 9. Projecões do saldo do Governo na comercialização de álcool carburante. Brasil, 1991-95.

Cr\$ bilhões, valores de dez.90

\begin{tabular}{lrcr}
\hline Ano & Otimista & Intermediário & Pessimista \\
\hline 1991 & 66,83 & 20,64 & 12,12 \\
1992 & 113,96 & 30,94 & $-1,57$ \\
1993 & 244,22 & 44,56 & $-51,64$ \\
1994 & 300,50 & 49,70 & $-107,54$ \\
1995 & 336,30 & 55,20 & $-163,44$ \\
\hline
\end{tabular}

FONTE: Apêndices 19,20 e 21 .

Pelos dados da Tabela 9, pode-se inferir que 
os pressupostos adotados para construção dos cenários, no seu conjunto, mostraram coerência por resultarem, num dado ano, em saldos crescentes no sentido pessimista-intermediário-otimista.

Nos cenários otimista e intermediário, os saldos previstos são sempre positivos, ao passo que no cenário pessimista passam a ser negativos a partir de 1992. Atentando-se para os Apêndices 19,20 e 21, e admitindo-se que a capacidade instalada de produção de álcool gira em torno de 16 bilhões de litros por safra, percebe-se que:

a) No cenário otimista, haveria demanda decrescente por álcool carburante $(8,6$ bilhões de litros em 1995, contra 11,1 bilhões de litros em 1991), o que poderia trazer problemas de natureza econômica para o setor agroindustrial alcooleiro;

b) No cenário intermediário, o consumo total projetado de álcool carburante é praticamente estável, entre 11,3 e 11,7 bilhões de litros por ano, bastante próximo do consumo verificado no período 1988-90;

c) No cenário pessimista, além do próprio fato de se projetarem saldos do Governo negativos, haveria problemas de suprimento da demanda a partir de 1993-94, claramente sendo impossivel satisfazê-la, com a atual capacidade instalada, a partir de 1994. Lembrar que, além de seu uso como carburante, o álcool etílico é destinado a uma série de outras finalidades.

De modo geral, depreende-se deste estudo que, pelo menos no período 1985-90, a participação do Governo na comercialização de álcool carburante resultou em saldos anuais sempre positivos. Aceitos os pressupostos aqui enunciados, ficam prejudicadas as afirmaçōes de que o PROÁLCOOL vinha sendo deficitário do ponto de vista financeiro do Governo. 
As projeções para o período 1991-95 indicam que os saldos do Governo seriam negativos apenas no cenário pessimista, a partir de 1992. Para que tal ocorra, à luz deste estudo, será necessário que se conjuguem diversos fatores, como crescimento do PIB e dos preços médios dos combustiveis a taxas muito pequenas $e$, no segundo caso, os pregos do óleo diesel estariam aumentando mais que proporcionalmente em relação aos combustiveis ciclo otto (encarecendo, inclusive, os custos de transporte do álcool).

Outro fator seria taxas de mistura de álcool anidro à gasolina bastante abaixo do tecnicamente possivel e do que se convenolonou adotar como adequado para não agravar os problemas de poluição atmosférica, principalmente nas grandes cidades.

Além disso, o resultado do balanço entre receitas e despesas do Governo seria decrescente por unidade de volume transacionada ( $\mathrm{Cr} \$ /$ litro), tanto para o álcool anidro como para o álcool hidratado, este último deficitário mesmo antes de se considerarem os custos de transporte e armazenagem.

Este trabalho ostenta algumas fragilidades teóricas, principalmente no que se refere à metodologia adotada na projeção dos valores de variáveis utilizadas na contrução dos cenários. Além disso, os custos de transporte e armazenagem levantados não dão margem a controles seguros de sua coerência.

Assim, registre-se a sugestão para que estes dois últimos aspectos sejam melhor estruturados em eventuais estudos de natureza semelhante. 


\section{CONCLUSÕES}

A motivação para este trabalho nesceu da constatação de que existe uma polêmica na sociedade brasileira sobre o saldo financeiro do Governo - entendido como as estruturas do Poder Executivo nas esferas federal, estadual e municipal - resultante de sua participacão na comercialização de álcool carburante.

Os objetivos principais foram analisar as estruturas de formação dos custos e dos preços dos combustíveis para avaliar o saldo do Governo na comercialização do álcool, bem como desenvolver modelo matemático para estimar o saldo em cenários construidos a partir de hipóteses econômicas alternativas.

Pelo menos no período-base coberto pelo estudo (1981-90), as despesas do Governo, todas no âmbito federal, foram representadas pela aquisição de álcool dos produtores, pelos subsidios de equalização de custos (para algumas regiões do país), pelo transporte do álcool anidro das destilarias até centros estatais de mistura à gasolina, pelos custos de mistura, manuseio e armazenagem (incluindo perdas) e pelo ressarcimento às empresas distribuidoras das despesas de transporte. Por outro lado, as receltas foram obtidas mediante venda dos produtos às dietribuidoras e via arrecadacão de tributos, estes repartidos entre a União, os estados e os municipios, sob a égide da legislacão vigente a cada época.

Os modelos matemáticos propostos para estimar a demanda total por carburantes para transportes 
58.

(medida em tEP) assumiram a forma semilogaritmica, tomando como variáveis explicativas a demanda defasada (ano anterior), o Produto Interno Bruto e o preço médio dos combustiveis ao consumidor. Neste caso, tratando-se de modelos com variável defasada, surge o risco de autocorrelação nos resíduos. En virtude disto, utilizou-se um método de ajustamento estatístico por mínimos quadrados generalizados em três etapas.

Pelo teste de significância unilateral, cada um dos parametros das três variáveis mostrou-se significativo em níveis de no máximo $5 \%$.

Para a funcão que relaciona as demandas por combustiveis diesel e ciclo otto, tomando-se como variáveis explicativas a relação entre as demandas no ano anterior e - preço relativo entre ciclo otto e diesel, confrontaram-se a forma semilogarítmica com a forma exponencial, adotandose o mesmo procedimento estatíctico mencionado para a função de demanda total. Os resultados conduziram à preferência pela função exponencial. Também neste caso, o teste unilateral indicou significância em níveis de no máximo $5 \%$ para cada um dos parâmetros.

De posse das funçōes estimadas de demanda total e de relaçóes entre demandas por diesel e ciclo otto, obteve-se, a partir delas, a expressão para estimar a demanda por combustiveis ciclo otto.

Através de desenvolvimento algébrico, levando-se em conta relacooes entre unidades $\left(t E P / \mathrm{m}^{3}\right)$ e a fraça volumétrica de álcool anidro na mistura com gasolina, obteve-se a expressão matemática que dá a demanda estimada por combustiveis ciclo otto em função dos consumos, em volume, de álcool anidro e de álcool hidratado. Evidentemente, a demanda de álcool anidro ou de álcool hidratado passa a ser uma funçao inversa das outras duas variáveis. Neste 
59.

trabalho, prefixou-se a demanda estimada de álcool hidratado; desta forma, sendo conhecidos os coeficientes de transformação em tEP e a taxa de álcool anidro na mistura com gasolina, tem-se a expressão que estima a demanda por álcool anidro em função da demanda por combustivels ciclo otto e da demanda por álcool hidratado.

Introduzindo-se o artificio de relacionar os elementos de receita e os elementos de despesa do Governo (exceto transporte e armazenagem ${ }^{15}$ ) com o preço da gasolina ao consumidor final, obtiveram-se somatórios dessas relacões, tanto para o álcool anidro como para o álcool hidratado, que permitem verificar, de antemão, se o sinal é positivo ou negativo para um e outro produto, mas não para os dois em conjunto (V. Apêndice 17). Lembrar que até este ponto não estão computados os custos de transporte e armazenagem.

Em seguida, construiu-se uma expressão que dá o saldo do Governo em função do consumo de álcool anidro, do consumo de álcool hidratado, dos respectivos somatórios das relaçöes com o preço da gasolina, deste preço e das despesas governamentais com transporte e armazenagem de álcool.

Com vistas à utilização dessa expressão em projeçōes, montaram-se cenários levando-se em conta todas as variáveis envolvidas e atribuindo-se às mesmas valores para o período 1991-95, sob três perspectivas: otimista, intermediária e pessimista.

Para o periodo 1981-84, não fol possível obter todos os dados de custos de transporte e armazenagem; nesse periodo, todos os saldos anuais foram positivos,

15 Os dados conseguidos sobre este ilem agregam as despesas para álcool anidro e álcool hidratado. 
60.

ressalvando-se, pelo motivo apontado, que seus valores foram sobrestimados.

No periodo 1985-90, com os custos de transporte e armazenagem completos, todos os saldos anuais foram positivos. Dada a efemeridade conferida a valores em cruzeiros por uma economia com altas taxas de desvalorização da moeda, apresentam-se a seguir os valores dos saldos anuais convertidos em moeda considerada mais estável, no caso o dólar norte-americano, tomando-se a relação cambial de dezembro de 1990 (US\$ $1,00=C_{r} \$ 155,45$ ). Os valores obtidos para o período 1985-90 foram, respectivamente, de 156; 595; 936; 1.169; 155 e 153 milhões de dólares.

As projeções para o período 1991-95 mostraram, adotando-se a mesma relação cambial, os seguintes resultados:

a) Cenário otimista (1991-95): todos os saldos anuais positivos, respectivamente $430 ; 733 ; 1.571$; 1.938 e 2.136 milhões de dólares.

b) Cenário intermediário (1991-95): todos OB saldos positivos, respectivamente de $133 ; 199 ; 287 ; 320$ e 355 milhões de dólares.

c) Cenário pessimista: saldo positivo em 1991, de 78 milhões de dólares; no período 1992-95, projeção de saldos negativos, respectivamente de 10; 332; 692 e 1.051 milhões de dólares.

Comparando-se a demanda projetada por álcool carburante com a capacidade instalada de fabricação do produto (ao redor de 16 bilhões de litros por ano), verificouse que, no cenário otimista, haveria redução acentuada da demanda, podendo acarretar problemas de natureza sócioeconómica para o setor sucroalcooleiro; no cenário intermediário, a demanda seria mais ou menos estável e próxima do consumo no final do periodo-base do estudo; no cenário pes- 
simista, a demanda cresceria de forma acentuada, trazendo sérios problemas de oferta, com a atual capacidade instalada de produção, a partir de 1993-94.

- desenvolvimento deste trabalho mostrou algumas fragilidades, tanto no que diz respeito à "confiabilidade" dos dados como de natureza metodológica. Aseim, o uso de series temporats de dados gerados por organismos oficiais padece do problema de acesso aos mesmos, de continuidade da metodologia e da operação de coleta e da presteza com que são colocados à disposição para consultas.

Metodologicamente, este trabalho apresentou dificuldades no embasamento teórico para montagem dos cenários, isto é, na projeção dos valores atribuídos às variáveis envolvidas no modelo. Outro aspecto a ressaltar é que, dada a mobilidade adotada pelo Governo nas politicas de preços e de tributaça dos combustiveis, a seguranca nas projeções é bastante tênue, transformando esse procedimento num exercicio de verificação do modelo.

Como observação relacionada a políticas econômicas, os resultados deste estudo Indicam que o Governo não tem necessidade de "liquidar" com o programa do álcool combustível. Especialmente no caso do álcool anidro, políticas direcionadas ao aumento da oferta do produto permitiriam recuperar as taxas de mistura à gasolina tidas como desejáveis do ponto de vista ambiental, sem que isso viesse a acarretar riscos quanto ao retorno econômico da iniciativa.

Ao final, registrem-se algumas sugestões a eventuais interessados em estudos de natureza semelhante ao aqui apresentado:

a) verificação dos custos de transporte $e$ armazenagem do álcool, de preferência recorrendo a um leque maior de fontes de informação; 
b) estruturação de metodologia mais consistente na projeção dos valores de variáveis envolvidas na construção dos cenários;

c) possibilidade de se utilizarem dados mensais - em lugar dos valores anuais aqui empregados na análise dos fluxos fístcos e financeiros, o que permit1ria, inclusive, averiguar se há ocorrência de saldos negativos temporários;

d) análise dos impactos financeiros separadamente para as esferas federal, estadual e municipal. 


\section{REFERÊNCIAS BIBLIOQRÁFICAS}

ASSOCIACÃO DE USINEIROS DE SÃO PAULO. São Paulo. Prorural : cálculo da contribuição sobre a cana; critério da oS/

IAPAS/SAF no 042/86. São Paulo, fev.1986. 2p.

BARROS, G.S.C. Economia da comercializacáo agricola. Piracicaba, FEALQ, 1987.306 .

BORGES, U.; FREITAG, H.; HURTIENNE, T.; NITSCH, M. Proálcool: análige do programa brasileiro de combustivel bioenergético. (Documentos para discussão, 13) 2 . ed. Berlim, Instituto Latinoamericano da Universidade Livre de Berlim, 1983. n.p.

BRASIL. Constituição. Constituiç̃o: República Federativa do Brasil. Belém, Banco da Amazônia S/A, 1988. 272 p. CENAL. Comissão Executiva Nacional do Alcool. Brasilia. Relatório Anual 1988 . Brasilia, s.d., n.p. CONJUNTURA ECONOMICA. Rio de Janeiro, FGV/IBRE, 32(1):139, jan. 1978.

CONJUNTURA ECONOMICA. Rio de Janeiro, FGV/IBRE, 34(1):111, jan. 1980.

CONJUNTURA ECONOMICA. Rio de Janeiro, FGV/IBRE, $37(1): 119$, jan. 1983.

CONJUNTURA ECONOMICA. Rio de Janeiro, FGV/IBRE, 39(1):135, jan. 1985.

CONJUNTURA ECONOMICA. Rio de Janeiro, FGV/IBRE, $43(1): 123$, jan. 1989.

COPERSUCAR. Cooperativa de Produtores de Cana, Acúcar e Álcool do Estado de São Paulo. São Paulo. PRoÁlCool: fundamentos e perspectivas. São Paulo, 1989. 121p. 
COSTA, O.A. Polftica de fixacão de precos dos derivados de petróleo e do álcool. São Paulo, SOPRAL, 1983. 12p. DATAGRo. Cana, acuúcar e álcool. Säo Paulo, (24), dez.1991. FERNANDES, M. de L. \& CASTRO, R. de F. Comentários sobre as estruturas de precos de gasolina e de álcool. Brasilia, CENAL, 1984, 29 p.

FUNDACÃ̃O JOÃO PINHEIRO, Belo Horizonte. Resultado final da comercializacão de álcool carburante: conta álcool e conta governo. Brasilia, 1986. 55p.

HOFFMANN, R. \& VIEIRA, S. Análise de regressão: uma introdução à econometria. 2. ed., São Paulo, Hucitec, 1987. p. 243-75.

IAA. Instituto do Acúcar e do Álcool. Rio de Janeiro. Coletânea de resoluções do conselho deliberativo: coletânea de atos da presidência. Rio de Janeiro, 1979-88.

IAA. Instituto do Acúcar e do Álcool. Rio de Janeiro. Boletim estatístico: álcool. Rio de Janeiro, 1980-88. INFORMATIVO SÓCIO-ECONOMICO. Piracicaba, IAA/PLANALSUCAR SUPER (5):1-14, jul. 1986.

INFORME ESTATI STICO SEMESTRAL № 9. Brasil1a, MIC/SG/SCO, $5(2): 92-108$, set. 1986 .

MINFRA. Ministério da Infra-Estrutura. Secretaria Nacional de Energia. Brasilia. Balanco energético nacional 1990: ano base 1989. Brasilia, 1990. 144p.

MINFRA. Miniatério da Infra-Estrutura. Secretaria Nacional de Energia. Brasilia. Boletim do balanco energético nacional : ano base 1990; dados preliminares. Brasilia, 1991, 13p.

MIC/STI. Ministério de Indústria e Comércio. Secretaria de Tecnologia Industrial. Avaliacão do Programa Nacional do Álcool. Brasilia, 1985. 175p.

MIC/STI. Ministério de Indústria e Comércio, Secretaria de Tecnologia Industrial. Previsão e análise tecnológica do Proálcool. Brasília, 1984. 2 v. 
65.

MME. Ministério de Minas e Energia. Brasilia. Balanco energético nacional: ano base 1987. Brasília, 1988. $139 p$.

OLIVEIRA, A.J.G. \& ALVIM, C.F. Perspectivas para a oferta e demanda de combustíveis líquidos nos próximos anos no Brasil. In: SEMINARIO DE TECNOLOGIA INDUSTRIAL DE PRODUĞ̃̃o DE ÁlCOOL, 1. Brasilia, 1985. Anais. Brasilia, 1985. MIC/STI, 1985. p. 461-81.

PAMPLONA, C. Proálcool: impacto em termos técnicoeconômicos e sociais do programa no Brasil. Belo Horizonte, MIC/IAA, 1984. 93 p.

PELIN, E. R. Avaliacão econômica do álcool hidratado no curto e médio prazos. São Paulo, IPE/USP, 1985, 280p.

PETROBRÁS. Rio de Janeiro. A Petrobrás e o álcool. Rio de Janeiro, Petrobrás, 1983, 16p.

PETROBRÁS. Rio de Janeiro. O dinheiro que você paga na gasolina não fica girando só aqui. s.n.t.

SUMA ECONôMICA. Rio de Janeiro. Tama, mai. 1989.

SUMA ECONôMICA. Rio de Janeiro. Tama, set. 1991.

WORLD BANK. Brazil : alcohol rationalization and efficlency project. s.n.t. 113 p. 
APÊHDICE 1. Exemplo de estrutura de preços do alcool carburante no nivel de produção ${ }^{\circ}$.

CI $\$$ IItro

\begin{tabular}{|c|c|c|c|c|c|c|}
\hline \multirow{3}{*}{ Itens } & \multicolumn{4}{|c|}{ Centro-5ul } & \multirow{2}{*}{\multicolumn{2}{|c|}{$\begin{array}{l}\text { Horte- } \\
\text { Hordeste }\end{array}$}} \\
\hline & \multicolumn{2}{|c|}{ R.de Janeiro } & \multicolumn{2}{|c|}{ Demais } & & \\
\hline & Anidro & Hidrat & Anidro & Hidrat & Anidro & Hidrat \\
\hline Valor de paridade & 192.12 & 180.53 & 191.12 & 180.53 & 191.12 & 180.53 \\
\hline PIS s/matéria-prima & 0.84 & 0.81 & 0.75 & 0.72 & 1.09 & 1.05 \\
\hline Finsocial s/matéria-prina & 0.77 & 0.74 & 0.69 & 0.67 & 1.00 & 0.97 \\
\hline ICmS s/matéria-prima & 21.89 & 21.10 & 19.67 & 18.96 & 2B.39 & 27.36 \\
\hline Preço de paridade & 214.62 & 203.18 & 212.23 & 200.88 & 221.60 & 209.91 \\
\hline PIS s/faturamento & 1.41 & 1.34 & 1.40 & 1.32 & 1.46 & 1.38 \\
\hline Finsocial s/faturamento & 1.30 & 1.23 & 1.29 & 1.22 & 1.35 & 1.28 \\
\hline Preça de faturamento ${ }^{b}$ & 217.33 & 205.75 & 214.92 & 203.42 & 224.41 & 212.57 \\
\hline
\end{tabular}

FONTE: IAA. Ato no 66/BB, de 30/12/88, Anexos XVIII e XXVI.

a Valores correntes $\left(C_{z} \$ 1000=N C_{1} \$ 1,00=\operatorname{Cr} \$ 1,00\right)$.

b Condição PVU ou PVD. 
APÊHDICE 2. Preços oficiais da cana-de-açacar ${ }^{\circ}$. Brasil, 1980-90.

Unidades monetárias correntes ${ }^{b} / t$

\begin{tabular}{|c|c|c|c|c|c|c|}
\hline \multirow{2}{*}{ Vigencia } & \multicolumn{3}{|c|}{ Centra-Sul } & \multicolumn{3}{|c|}{ Norte-Mordeste } \\
\hline & Campo & Transp & Esteira & Campo & Transp & Esteira \\
\hline $01 / 01 / 80$ & 341.10 & 42.43 & 385.80 & 462.18 & 42.43 & 606.14 \\
\hline $05 / 05 / 80$ & 537.93 & 51.47 & 594.21 & 783.85 & 51.47 & 1003.27 \\
\hline $26 / 09 / 80$ & 742.35 & 71.03 & 820.01 & 1081.57 & 71.03 & 1384.50 \\
\hline $07 / 01 / 81$ & 742.35 & 71.03 & 820.01 & 1081.57 & 71.03 & 1384.50 \\
\hline $29 / 01 / 81$ & 875.97 & 83.82 & 1146.16 & 1276.25 & 83.82 & 1633.72 \\
\hline $18 / 05 / 81$ & 1119.74 & 107.13 & 1465.13 & 1624.67 & 106.70 & 2079.72 \\
\hline $02 / 10 / 81$ & 1479.66 & 166.40 & 1965.73 & 2121.57 & 198.47 & 2786.83 \\
\hline $11 / 01 / 82$ & 1479.66 & 166.40 & 1977.25 & 2121.57 & 198.47 & 2786.83 \\
\hline $20 / 03 / 82$ & 1783.51 & 200.54 & 2383.23 & 2558.61 & 239.35 & 3360.91 \\
\hline $17 / 07 / 82$ & 2212.21 & 248.66 & 2973.07 & 3172.68 & 296.79 & 4192.71 \\
\hline $01 / 10 / 82$ & 2897.12 & 325.75 & 3894.71 & 4156.21 & 388.80 & 5492.46 \\
\hline $09 / 03 / 83$ & 3557.88 & 399.39 & 478 & 14 & -22 & 6755.73 \\
\hline $01 / 06 / 83$ & 4703.51 & 527.99 & 6322.07 & 6758.25 & 632.21 & 8931.07 \\
\hline $30 / 09 / 83$ & 6984.72 & 784.07 & 9388.27 & 10036.00 & 938.83 & 13262.63 \\
\hline $01 / 01 / 84$ & 6984.72 & 784.07 & 9503.11 & 10036.00 & 938.83 & 13424.87 \\
\hline $3 / 02 / 84$ & 10197.69 & 1144.75 & 13874.54 & 14652.56 & 1370.69 & 19600.31 \\
\hline $01 / 06 / 84$ & 14997.33 & 1728.20 & 20462.40 & 19066.29 & 1860.85 & 25563.92 \\
\hline $09 / 08 / 84$ & 14997.33 & 1728.20 & 20462.40 & 19066.29 & 1860.85 & 25563.92 \\
\hline $24 / 09 / 84$ & 22497.58 & 2592.30 & 98 & 2869 & .25 & 38398.40 \\
\hline $06 / 02 / 85$ & 33746.37 & 3888.46 & 46036.48 & 42899.16 & 4186.88 & 57597.60 \\
\hline $01 / 06 / 85$ & 47093.22 & 5438.07 & 64258.46 & 57956.77 & 5656.47 & 77814.36 \\
\hline $25 / 09 / 85$ & 67814.92 & 7830.90 & 92533.10 & B3457.75 & 8145.32 & 112052.69 \\
\hline $01 / 01 / 86$ & 84768.64 & 9788.62 & 115666.38 & 104322.19 & 10181.65 & 140065.86 \\
\hline $28 / 02 / 86$ & 14.77 & 9.79 & 115.61 & 104.32 & 10.18 & 140.06 \\
\hline $21 / 11 / 86$ & 111.89 & 12.93 & 152.68 & 137.70 & 13.44 & 184.88 \\
\hline 10.02 .87 & 143.22 & 16.54 & 195.43 & 190.03 & 18.55 & 255.14 \\
\hline $01 / 05 / 87$ & 264.96 & 30.61 & 351.56 & 351.56 & 34.32 & 472.02 \\
\hline $01 / 06 / 87$ & 319.54 & 36.92 & 436.05 & 423.42 & 41.34 & 568.51 \\
\hline & & & & & & continua) \\
\hline
\end{tabular}


68.

(cont.) APÊMDICE 2. Preços oficiais da cana-de-açacar ${ }^{a}$. Brasil, 1980-90.

Unidades monetárias correntes ${ }^{b} / t$

\begin{tabular}{|c|c|c|c|c|c|c|}
\hline \multirow{2}{*}{ Vigência } & \multicolumn{3}{|c|}{ Centro-Sul } & \multicolumn{3}{|c|}{ Horte-Hordeste } \\
\hline & Campo & Transp & Esteira & Campo & Transp & Esteira \\
\hline $03 / 07 / 87$ & 319.54 & 36.92 & 436.05 & 423.42 & 41.34 & 568.51 \\
\hline $04 / 09 / 87$ & 367.47 & 42.47 & 501.44 & 486.96 & 47.54 & 653.82 \\
\hline $08 / 10 / 87$ & 424.43 & 49.05 & 579.18 & 562.44 & 54.91 & 755.17 \\
\hline $01 / 11 / 87$ & 462.63 & 53.46 & 631.01 & 613.06 & 59.85 & 823.13 \\
\hline $04 / 12 / 87$ & 522.03 & 60.32 & 712.36 & 691.78 & 67.53 & 928.82 \\
\hline $11 / 01 / 88$ & 595.84 & 68.85 & 814.07 & 789.60 & 77.08 & 1061.46 \\
\hline $09 / 02 / 88$ & 694.21 & 80.22 & 948.48 & 919.96 & 89.81 & 1236.71 \\
\hline $14 / 03 / 88$ & 807.16 & 93.27 & 1102.78 & 1069.63 & 104.42 & 1437.90 \\
\hline $20 / 04 / 88$ & 936.39 & 108.20 & 1279.35 & 1240.88 & 121.14 & 1668.12 \\
\hline $20 / 05 / 88$ & 1340.34 & 154.88 & 1831.26 & 1776.19 & 173.40 & 2387.75 \\
\hline $22 / 06 / 88$ & 1578.65 & 182.42 & 2156.85 & 2092.00 & 204.23 & 2812.28 \\
\hline $30 / 07 / 88$ & 1944.90 & 224.74 & 2653.98 & 2577.34 & 251.61 & 3460.48 \\
\hline $23 / 08 / 88$ & 2351.19 & 271.69 & 3208.39 & 3115.75 & 304.17 & 4183.39 \\
\hline $23 / 09 / 88$ & 2868.45 & 331.46 & 3914.25 & 3801.22 & 371.09 & 5103.74 \\
\hline $26 / 10 / 88$ & 3802.13 & 439.35 & 5188.35 & 5038.52 & 491.88 & 6765.01 \\
\hline $01 / 12 / 88$ & 4752.66 & 549.19 & 6485.44 & 6298.15 & 614.85 & 8456.28 \\
\hline $30 / 12 / 88$ & 5938.21 & 686.49 & 8106.80 & 7862.69 & 768.56 & 10570.34 \\
\hline 13/01/89 & 7.50 & 0.89 & 10.19 & 9.94 & 0.97 & 13.29 \\
\hline $09 / 05 / 89$ & 8.70 & 1.01 & 11.82 & 11.53 & 1.13 & 15.42 \\
\hline $15 / 06 / 89$ & 10.61 & 1.24 & 14.42 & 14.07 & 1.38 & 18.81 \\
\hline $13 / 07 / 89$ & 14.64 & 1.71 & 19.90 & 19.40 & 1.91 & 25.94 \\
\hline 07/08/89 & 16.54 & 1.93 & 22.48 & 21.92 & 2.16 & 29.31 \\
\hline $16 / 08 / 89$ & 21.30 & 2.49 & 28.95 & 28.22 & 2.78 & 37.74 \\
\hline $31 / 08 / 89$ & 21.30 & 2.49 & 29.13 & 28.22 & 2.78 & 37.96 \\
\hline $05 / 09 / 89$ & 24.07 & 2.80 & 32.92 & 31.89 & 3.14 & 42.90 \\
\hline $15 / 09 / 89$ & 32.71 & 3.82 & 44.74 & 43.34 & 4.27 & 58.30 \\
\hline $16 / 10 / 89$ & 43.29 & 5.05 & 58.27 & 57.36 & 5.66 & 77.18 \\
\hline $31 / 10 / 89$ & 48.06 & 5.61 & 65.73 & 63.67 & 6.28 & 85.67 \\
\hline
\end{tabular}


(cont.) APÊNDICE 2. Preços oficiais da cana-de-açucar ${ }^{\circ}$. Brasil, 1980-90. Unidades monetárias correntes ${ }^{b} / t$

\begin{tabular}{|c|c|c|c|c|c|c|}
\hline \multirow{2}{*}{ Vigencia } & \multicolumn{3}{|c|}{ Centro-Sul } & \multicolumn{3}{|c|}{ Horte-Hordeste } \\
\hline & Campo & Transp & Esteira & Campo & Transp & Esteira \\
\hline $16 / 11 / 89$ & 66.14 & 7.72 & 90.46 & 87.63 & 8.64 & 117.90 \\
\hline $06 / 12 / 89$ & 93.53 & 10.92 & 127.93 & 123.93 & 12.22 & 166.75 \\
\hline $28 / 12 / 89$ & 143.67 & 16.77 & 199.37 & 190.36 & 18.77 & 257.23 \\
\hline $31 / 01 / 90$ & 224.56 & 26.18 & 311.27 & 297.17 & 29.36 & 402.46 \\
\hline $20 / 02 / 90$ & 273.23 & 31.89 & 379.22 & 362.04 & 35.70 & 490.20 \\
\hline $01 / 03 / 90$ & 387.50 & 45.23 & 537.81 & 513.45 & 50.62 & 695.21 \\
\hline $15 / 03 / 90$ & 511.90 & 59.76 & 712.13 & 678.22 & 66.87 & 918.79 \\
\hline $06 / 08 / 90$ & 588.68 & 68.72 & 820.32 & 780.01 & 76.90 & 1052.60 \\
\hline $14 / 08 / 90$ & 676.98 & 79.03 & 941.79 & 897.01 & 88.44 & 1215.10 \\
\hline $05 / 09 / 90$ & 758.22 & 88.51 & 1054.78 & 1004.65 & 99.05 & 1360.90 \\
\hline $10 / 10 / 90$ & 909.86 & 106.21 & 1265.71 & 1205.58 & 118.86 & 1633.10 \\
\hline $07 / 11 / 90$ & 1211.57 & 141.42 & 1685.47 & 1605.35 & 158.27 & 2174.62 \\
\hline $06 / 12 / 90$ & 1320.61 & 154.15 & 1837.16 & 1749.83 & 172.51 & 2370.33 \\
\hline
\end{tabular}

FOHTE: IAA (1980-88); Diário Oficial da União.

a Valores ponderados pelas produçōes anuais dos Estados.

b Até 27/02/86: Cr\$; a partir de 28/02/86: C7\$; a partir de 16/01/89: HCI\$; a partir de 16/03/90= Cr\$. 
70.

APÊNDICE 3. Estrutura de preços do álcool anidro carburante no nivel de produçãoa . Brasil, 1980-90.

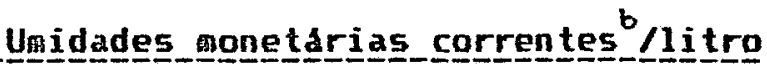

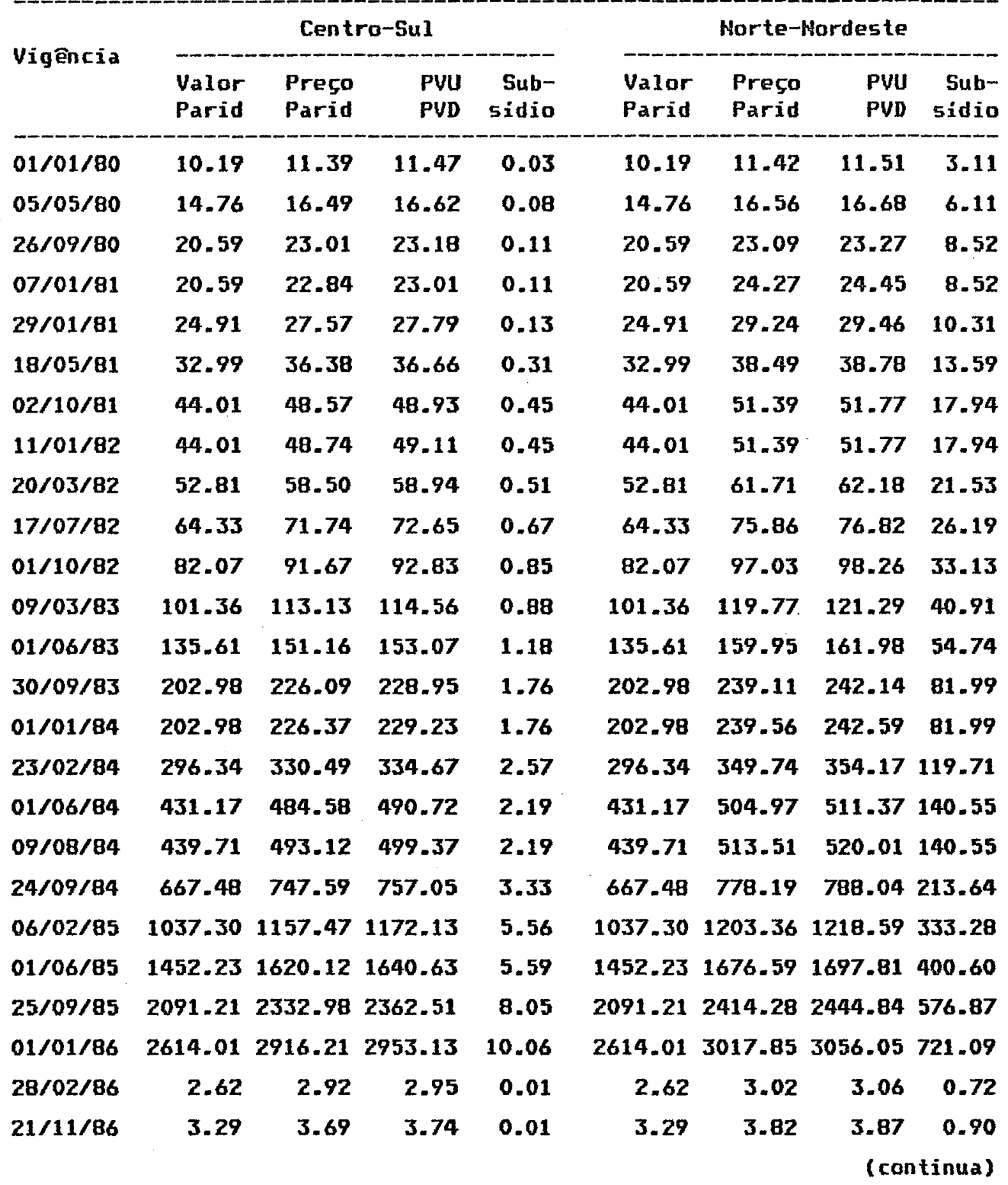


(cont.) APÊHDICE 3. Estrutura de preços do alcool anidro carburante no nivel de produção ${ }^{\alpha}$. Brasil, 1980-90.

Unidades monetźria

\begin{tabular}{|c|c|c|c|c|c|c|c|c|}
\hline \multirow{2}{*}{ Vigência } & \multicolumn{4}{|c|}{ Centro-Sul } & \multicolumn{4}{|c|}{ Norte-Mordeste } \\
\hline & $\begin{array}{l}\text { Valor } \\
\text { Parid }\end{array}$ & $\begin{array}{l}\text { Preço } \\
\text { Parid }\end{array}$ & $\begin{array}{l}\text { PVU } \\
\text { PVD }\end{array}$ & $\begin{array}{r}\text { Sub- } \\
\text { sidio }\end{array}$ & $\begin{array}{l}\text { Valor } \\
\text { Parid }\end{array}$ & $\begin{array}{l}\text { Preço } \\
\text { Parid }\end{array}$ & $\begin{array}{l}\text { PUU } \\
\text { PUD }\end{array}$ & $\begin{array}{r}\text { Sub- } \\
\text { sidio }\end{array}$ \\
\hline 10.02 .87 & 4.53 & 5.03 & 5.10 & 0.02 & 4.53 & 5.27 & 5.34 & 1.13 \\
\hline $01 / 05 / 87$ & 8.39 & 9.34 & 9.46 & 0.03 & 8.39 & 9.76 & 9.88 & 2.09 \\
\hline $01 / 06 / 87$ & 10.15 & 11.69 & 11.44 & 0.03 & 10.15 & 11.76 & 11.94 & 2.58 \\
\hline $03 / 07 / 87$ & 10.42 & 11.56 & 11.71 & 0.03 & 10.42 & 12.06 & 12.21 & 2.65 \\
\hline $04 / 09 / 87$ & 11.99 & 13.30 & 13.47 & 0.04 & 11.99 & 13.88 & 14.06 & 3.05 \\
\hline $08 / 10 / 87$ & 13.84 & 15.35 & 15.55 & 0.05 & 13.84 & 16.02 & 16.22 & 3.52 \\
\hline $01 / 11 / 87$ & 15.09 & 16.75 & 16.96 & 0.05 & 15.09 & 17.47 & 17.69 & 3.83 \\
\hline $04 / 12 / 87$ & 17.03 & 18.90 & 19.14 & 0.06 & 17.03 & 19.70 & 19.95 & 4.33 \\
\hline $11 / 01 / 88$ & 19.44 & 21.59 & 21.88 & 0.06 & 19.44 & 22.52 & 22.83 & 4.94 \\
\hline $09 / 02 / 88$ & 22.64 & 25.13 & 25.47 & 0.08 & 22.64 & 26.23 & 26.59 & 5.75 \\
\hline $14 / 03 / 88$ & 26.33 & 29.23 & 29.63 & 0.09 & 26.33 & 30.50 & 30.92 & 6.69 \\
\hline $20 / 04 / 89$ & 30.54 & 33.90 & $\mathbf{3 4 . 3 7}$ & 0.10 & 30.54 & 35.38 & 35.87 & 7.76 \\
\hline $20 / 05 / 88$ & 43.72 & 48.54 & 49.21 & 0.14 & 43.72 & 50.64 & 51.33 & 11.11 \\
\hline $22 / 06 / 88$ & 51.50 & 57.16 & 57.94 & 0.17 & 51.50 & 59.65 & 60.46 & 13.08 \\
\hline $30 / 07 / 88$ & 63.44 & 70.38 & 71.27 & 0.21 & 63.44 & 73.42 & 74.35 & 16.12 \\
\hline $23 / 08 / 88$ & 76.69 & 85.07 & 86.15 & 0.25 & 76.69 & 88.76 & 89.88 & 19.49 \\
\hline $23 / 09 / 8 B$ & 93.56 & 103.79 & 105.10 & 0.31 & 93.56 & 108.27 & 109.64 & 23.77 \\
\hline $26 / 10 / 88$ & 122.32 & 135.87 & 137.59 & 0.40 & 122.32 & 141.82 & 143.61 & 31.04 \\
\hline $01 / 12 / 88$ & 152.89 & 169.84 & 17 & 0 & 99 & 177.27 & 179.52 & 38.80 \\
\hline $30 / 12 / 88$ & 191.12 & 212.30 & 214.99 & 0.63 & 191.12 & 221.60 & 224.41 & 48.50 \\
\hline 13/01/89 & 0.24 & 0.26 & 0.27 & 0.00 & 0.24 & 0.27 & 0.28 & 0.06 \\
\hline $09 / 05 / 89$ & 0.27 & 0.31 & 0.34 & 0.00 & 0.27 & 0.32 & 0.34 & 0.07 \\
\hline $15 / 06 / 89$ & 0.32 & 0.36 & 0.40 & 0.00 & 0.32 & 0.38 & 0.40 & 0.08 \\
\hline $13 / 07 / 89$ & 0.45 & 0.51 & 0.55 & 0.00 & 0.45 & 0.53 & 0.56 & 0.11 \\
\hline $07 / 08 / 89$ & 0.51 & 0.57 & 0.62 & 0.00 & 0.51 & 0.60 & 0.63 & 0.13 \\
\hline $16 / 08 / 89$ & 0.66 & 0.74 & 0.80 & 0.00 & 0.66 & 0.77 & 0.81 & 0.16 \\
\hline $31 / 08 / 89$ & 0.66 & 0.74 & 0.81 & 0.00 & 0.66 & 0.77 & 0.82 & 0.16 \\
\hline
\end{tabular}


72.

(cont.) APÊHDICE 3. Estrutura de preços do álcool anidro carburante no nivel de produção ${ }^{a}$. Brasil, 1980-90.

Uni

\begin{tabular}{|c|c|c|c|c|c|c|c|c|}
\hline \multirow{2}{*}{ Vigência } & \multicolumn{4}{|c|}{ Centro-Sul } & \multicolumn{4}{|c|}{ Morte-Mordeste } \\
\hline & $\begin{array}{l}\text { Valor } \\
\text { Parid }\end{array}$ & $\begin{array}{l}\text { Preço } \\
\text { Parid }\end{array}$ & $\begin{array}{l}\text { PUU } \\
\text { PVD }\end{array}$ & $\begin{array}{l}\text { Sub- } \\
\text { sidio }\end{array}$ & $\begin{array}{l}\text { Valor } \\
\text { Parid }\end{array}$ & $\begin{array}{l}\text { Preço } \\
\text { Parid }\end{array}$ & $\begin{array}{l}\text { PVU } \\
\text { PVD }\end{array}$ & $\begin{array}{l}\text { Sub- } \\
\text { sidio }\end{array}$ \\
\hline $05 / 09 / 89$ & 0.75 & 0.83 & 0.92 & 0.00 & 0.75 & 0.87 & 0.93 & 0.19 \\
\hline $15 / 09 / 89$ & 1.02 & 1.13 & 1.25 & 0.00 & 1.02 & 1.19 & 1.26 & 0.25 \\
\hline $16 / 10 / 89$ & 1.35 & 1.50 & 1.65 & 0.00 & 1.35 & 1.57 & 1.67 & 0.33 \\
\hline $31 / 10 / 89$ & 1.49 & 1.67 & 1.83 & 0.00 & 1.49 & 1.74 & 1.85 & 0.37 \\
\hline $16 / 11 / 89$ & 2.05 & 2.29 & 2.53 & 0.01 & 2.05 & 2.40 & 2.55 & 0.51 \\
\hline $06 / 12 / 89$ & 2.91 & 3.24 & 3.57 & 0.01 & 2.91 & 3.39 & 3.60 & 0.72 \\
\hline $28 / 12 / 89$ & 4.46 & 5.02 & 5.57 & 0.01 & 4.46 & 5.22 & 5.57 & 1.11 \\
\hline $31 / 01 / 90$ & 6.97 & 7.85 & 8.72 & 0.02 & 6.97 & 8.17 & 8.74 & 1.73 \\
\hline $20 / 02 / 90$ & 8.66 & 9.75 & 10.83 & 0.03 & 8.66 & 10.15 & 10.85 & 2.15 \\
\hline $01 / 03 / 90$ & 12.04 & 13.56 & 15.09 & 0.04 & 12.04 & 14.06 & 15.09 & 2.99 \\
\hline $15 / 03 / 90$ & 15.91 & 17.91 & 19.94 & 0.05 & 15.91 & 18.65 & 19.94 & 3.95 \\
\hline $06 / 08 / 90$ & 18.29 & 20.60 & 22.93 & 0.06 & 18.29 & 21.44 & 22.29 & 4.54 \\
\hline $14 / 08 / 90$ & 21.04 & 23.69 & 26.39 & 0.07 & 21.04 & 24.66 & 26.37 & 5.23 \\
\hline $05 / 09 / 90$ & 23.56 & 26.58 & 29.53 & 0.07 & 23.56 & 27.62 & 29.54 & 5.85 \\
\hline $10 / 10 / 90$ & 28.28 & 31.84 & 35.44 & 0.09 & 28.28 & 33.45 & 35.87 & 7.02 \\
\hline $07 / 11 / 90$ & 36.12 & 40.86 & 45.30 & - & 45.05 & 51.70 & 56.96 & - \\
\hline $06 / 12 / 90$ & 39.27 & 44.43 & 49.25 & - & 49.10 & 55.93 & 62.08 & 一 \\
\hline
\end{tabular}

FOHTE: IAA (1980-88); Diário Oficial da União.

a Valores ponderados pelas produçöes anuais dos Estados.

b Até 27/02/86: Cr\$; a partir de 28/02/86: Cz\$; a partir de 16/01/89: MCz\$; a partir de $16 / 03 / 90$ : Cr\$. 
73.

APENDICE 4. Estrutura de preços do alcool hidratado carburante no nivel de produção ${ }^{a}$. Brasil, 1980-90.

Unid dades monetárias

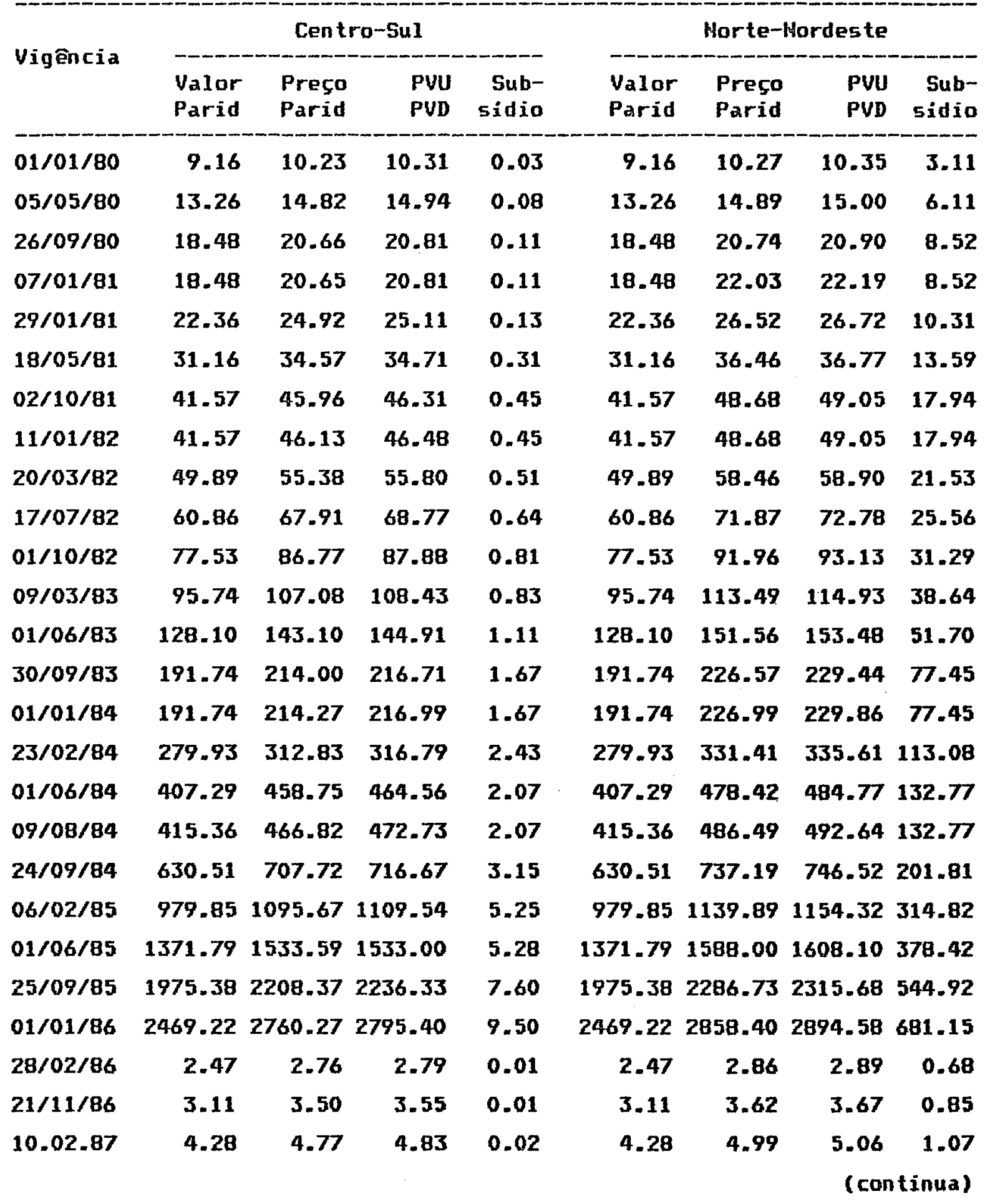


(cont.) APÊNDICE 4. Estrutura de preços do al cool hidratado carburante no nivel de produção ${ }^{\circ}$. Brasil, $1980-90$.

Umidades monetárias correntes ${ }^{b}$ l1 itro

\begin{tabular}{|c|c|c|c|c|c|c|c|c|}
\hline \multirow{2}{*}{ Vigência } & \multicolumn{4}{|c|}{ Centro-Sul } & \multicolumn{4}{|c|}{ Morte-Hordeste } \\
\hline & $\begin{array}{l}\text { Valor } \\
\text { Parid }\end{array}$ & $\begin{array}{l}\text { Preço } \\
\text { Parid }\end{array}$ & $\begin{array}{l}\text { PVU } \\
\text { PVD }\end{array}$ & $\begin{array}{r}\text { Sub- } \\
\text { sidio }\end{array}$ & $\begin{array}{l}\text { Valor } \\
\text { Parid }\end{array}$ & $\begin{array}{l}\text { Preço } \\
\text { Parid }\end{array}$ & $\begin{array}{l}\text { PVU } \\
\text { PUD }\end{array}$ & $\begin{array}{l}\text { Sub- } \\
\text { sidio }\end{array}$ \\
\hline $01 / 05 / 87$ & 7.92 & 8.83 & 8.94 & 0.03 & 7.92 & 9.23 & 9.35 & 1.97 \\
\hline $01 / 06 / 87$ & 9.59 & 10.68 & 10.81 & 0.03 & 9.59 & 11.16 & 11.30 & 2.44 \\
\hline $03 / 07 / 87$ & 9.84 & 10.93 & 11.07 & 0.03 & 9.84 & 11.41 & 11.56 & 2.50 \\
\hline $04 / 09 / 87$ & 11.32 & 12.57 & 12.73 & 0.04 & 11.32 & 13.13 & 13.30 & 2.88 \\
\hline $08 / 10 / 87$ & 13.08 & 14.53 & 14.71 & 0.04 & 13.08 & 15.18 & 15.38 & 3.32 \\
\hline $01 / 11 / 87$ & 14.25 & 15.84 & 16.04 & 0.05 & 14.25 & 16.53 & 16.74 & 3.62 \\
\hline $04 / 12 / 87$ & 16.09 & 17.89 & 18.12 & 0.05 & 16.09 & 18.67 & 18.90 & 4.09 \\
\hline $11 / 01 / 88$ & 18.36 & 20.42 & 20.70 & 0.06 & 18.36 & 21.33 & 21.62 & 4.66 \\
\hline $09 / 02 / 88$ & 21.38 & 23.79 & 24.11 & 0.07 & 21.38 & 24.83 & 25.17 & 5.44 \\
\hline $14 / 03 / 88$ & 24.87 & 27.66 & 28.04 & 0.08 & 24.87 & 28.88 & 29.28 & 6.32 \\
\hline $20 / 04 / 88$ & 28.85 & 32.09 & 32.53 & 0.10 & 28.85 & 33.51 & 33.96 & 7.33 \\
\hline $20 / 05 / 88$ & 41.30 & 45.94 & 46.57 & 0.14 & 41.30 & 47.97. & 48.62 & 10.49 \\
\hline $22 / 06 / 88$ & 48.64 & 54.10 & 54.84 & 0.16 & 48.64 & 56.50 & 55.27 & 12.36 \\
\hline $30 / 07 / 88$ & 59.93 & 66.62 & 67.46 & 0.20 & 59.93 & 69.55 & 70.43 & 15.23 \\
\hline $23 / 08 / 88$ & 72.44 & 80.52 & 81.54 & 0.24 & 72.44 & 84.06 & 85.12 & 18.41 \\
\hline 23/09/88 & 88.38 & 98.23 & 99.48 & 0.29 & 88.38 & 102.57 & 103.87 & 22.46 \\
\hline $26 / 10 / 88$ & 115.54 & 128.60 & 130.23 & 0.38 & 115.54 & 134.34 & 136.04 & 29.32 \\
\hline $01 / 12 / 88$ & 144.42 & 160.75 & 162.79 & 0.48 & 144.42 & 167.92 & 170.05 & 36.65 \\
\hline $30 / 12 / 88$ & 180.53 & 200.95 & 203.49 & 0.59 & 180.53 & 209.91 & 212.57 & 45.81 \\
\hline $13 / 01 / 89$ & 0.22 & 0.25 & 0.25 & 0.00 & 0.22 & 0.26 & 0.26 & 0.06 \\
\hline $09 / 05 / 89$ & 0.26 & 0.29 & 0.32 & 0.00 & 0.26 & 0.30 & 0.32 & 0.07 \\
\hline $15 / 06 / 89$ & 0.31 & 0.34 & 0.37 & 0.00 & 0.31 & 0.36 & 0.37 & 0.08 \\
\hline $13 / 07 / 89$ & 0.42 & 0.47 & 0.51 & 0.00 & 0.42 & 0.49 & 0.52 & 0.11 \\
\hline $07 / 08 / 89$ & 0.48 & 0.53 & 0.58 & 0.00 & 0.48 & 0.55 & 0.58 & 0.13 \\
\hline $16 / 08 / 89$ & 0.61 & 0.68 & 0.74 & 0.00 & 0.61 & 0.71 & 0.75 & 0.16 \\
\hline $31 / 08 / 89$ & 0.61 & 0.69 & 0.76 & 0.00 & 0.61 & 0.72 & $\begin{array}{l}0.76 \\
(\operatorname{con}\end{array}$ & $\begin{array}{l}0.16 \\
\text { inua) }\end{array}$ \\
\hline
\end{tabular}


(cont.) APÊADICE 4. Estrutura de preços do álcool hidratado carburante no nivel de produção ${ }^{\circ}$. Brasil, 1980-90.

Unidades_monetárias correntes ${ }^{b} / 1$ it tro

\begin{tabular}{|c|c|c|c|c|c|c|c|c|}
\hline \multirow{2}{*}{ Vigência } & \multicolumn{4}{|c|}{ Centro-Sul } & \multicolumn{4}{|c|}{ Morte-Mordeste } \\
\hline & $\begin{array}{l}\text { Valor } \\
\text { Parid }\end{array}$ & $\begin{array}{l}\text { Preço } \\
\text { Parid }\end{array}$ & $\begin{array}{l}\text { PVU } \\
\text { PVD }\end{array}$ & $\begin{array}{r}\text { Sub- } \\
\text { sidio }\end{array}$ & $\begin{array}{l}\text { Valor } \\
\text { Parid }\end{array}$ & $\begin{array}{l}\text { Preço } \\
\text { Parid }\end{array}$ & $\begin{array}{l}\text { PUU } \\
\text { PUD }\end{array}$ & $\begin{array}{l}\text { Sub- } \\
\text { sidio }\end{array}$ \\
\hline $05 / 09 / 89$ & 0.69 & 0.78 & 0.85 & 0.00 & 0.69 & 0.81 & 0.86 & 0.18 \\
\hline $15 / 09 / 89$ & 0.94 & 1.05 & 1.16 & 0.00 & 0.94 & 1.10 & 1.17 & 0.24 \\
\hline $16 / 10 / 89$ & 1.24 & 1.39 & 1.53 & 0.00 & 1.24 & 1.46 & 1.54 & 0.32 \\
\hline $31 / 10 / 89$ & 1.38 & 1.55 & 1.70 & 0.00 & 1.38 & 1.62 & 1.71 & 0.35 \\
\hline $16 / 11 / 89$ & 1.90 & 2.13 & 2.34 & 0.01 & 1.90 & 2.23 & 2.36 & 0.48 \\
\hline $06 / 12 / 89$ & 2.69 & 3.01 & 3.31 & 0.01 & 2.69 & 3.16 & 3.34 & 0.68 \\
\hline $28 / 12 / 89$ & 4.13 & 4.67 & 5.16 & 0.01 & 4.13 & 4.86 & 5.16 & 1.05 \\
\hline $31 / 01 / 90$ & 6.45 & 7.29 & 8.09 & 0.02 & 6.45 & 7.61 & 8.09 & 1.64 \\
\hline $20 / 02 / 90$ & 8.01 & 9.06 & 10.05 & 0.03 & 8.01 & 9.45 & 10.05 & 2.03 \\
\hline $01 / 03 / 90$ & 11.14 & 12.60 & 13.97 & 0.04 & 11.14 & 13.14 & 13.98 & 2.83 \\
\hline $15 / 03 / 90$ & 14.72 & 16.65 & 18.46 & 0.05 & 14.72 & 17.36 & 18.46 & 3.73 \\
\hline $06 / 08 / 90$ & 16.93 & 19.15 & 21.23 & 0.05 & 16.93 & 19.96 & 21.23 & 4.29 \\
\hline $14 / 08 / 90$ & 19.47 & 22.02 & 24.45 & 0.06 & 19.47 & 22.96 & 24.42 & 4.94 \\
\hline $05 / 09 / 90$ & 21.80 & 24.66 & 27.34 & 0.07 & 21.80 & 25.71 & 27.35 & 5.53 \\
\hline $10 / 10 / 90$ & 26.17 & 29.60 & 32.81 & 0.08 & 26.17 & 30.86 & 32.82 & 6.63 \\
\hline $07 / 11 / 90$ & 33.43 & 38.00 & 41.94 & - & 41.68 & 47.72 & 52.12 & - \\
\hline $06 / 12 / 90$ & 36.43 & 41.42 & 45.72 & - & 45.44 & 52.02 & 56.81 & - \\
\hline
\end{tabular}

FOHTE: IAA (1980-88); Diário Oficial da União.

a Valores ponderados pelas produçöes anuais dos Estados.

b Até 27/02/86: Cr\$; a partir de 28/02/86: Cz\$; a partir de 16/01/1989: HCI\$; a partir de 16/03/90= Cr\$. 
APÊHDICE 5. Consumo mensal aparente de álcool anidro para fins carburantes. Centro-Sul, 1981-90.

Hil ${ }^{3}$

\begin{tabular}{|c|c|c|c|c|c|c|c|c|c|c|}
\hline 5 & 1981 & 982 & 983 & 1984 & 1985 & 1986 & 1987 & 1988 & 1989 & 199 \\
\hline & & & & & & & & & & \\
\hline & & & & & & & & & & \\
\hline & 144.3 & & & & & & & & & 84.6 \\
\hline & 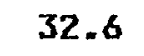 & & & & & & & & & 49.3 \\
\hline & & & & & & & & & & - \\
\hline & 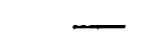 & 84.9 & & & & & & & & 68.6 \\
\hline & - & 188 & 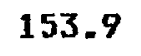 & & 200 & & 143.2 & & & \\
\hline & 100 & & & & & & & & & \\
\hline & 5 & 1 & & & & & & & & .7 \\
\hline & & & & & & & & & & \\
\hline 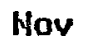 & 77.2 & & & & 16 & 17 & 13 & & & 1.2 \\
\hline & & 年 & 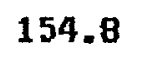 & . & 168 & 187.3 & 100 & 152 & w & (5) \\
\hline
\end{tabular}

FOHTES: 1) 1981-88: IAA;

2) 1989 : DATAGR0 (informação pessoal);

3) 1990: DATAGRO. 
APÊNDICE 6. Consumo mensal aparente de alcool anidro para fins carburantes. Horte-Nordeste, 1981-90.

$\operatorname{Mil} a^{3}$

\begin{tabular}{|c|c|c|c|c|c|c|c|c|c|c|}
\hline ês & 1981 & 982 & 1983 & 1984 & 1985 & 1986 & 1997 & 1988 & 1989 & 990 \\
\hline Wan & 25.0 & & res & & & & & & & 17.4 \\
\hline Fev & 21.2 & 24.0 & 37.3 & 0 & 20, & 333 & 107 & $?$ & $2 n 1$ & 12.4 \\
\hline lar & 21.9 & 26.5 & 32.4 & 29.9 & 19.1 & & & & & 17.7 \\
\hline (D) & 2 & t & 3 & & & & & & & 15.5 \\
\hline 2 & 200 & 20.0 & 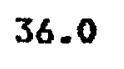 & 20.5 & 0.0 & 25. & & & & 14.2 \\
\hline Iun & 14.1 & 21.7 & 27.2 & 26.7 & 24.0 & 32.8 & 17.4 & 22.2 & & 12.7 \\
\hline Iul & & & & & & & & & & 14.5 \\
\hline go & & & & & & & & & & 17.1 \\
\hline te & $12=2$ & 20.2 & & & $20=0$ & 36.1 & & & & 12.5 \\
\hline oul & .1 & 32.7 & 33.1 & 39.7 & 33.5 & 34.7 & 27.8 & 23.7 & 14.1 & 19.6 \\
\hline 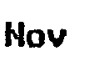 & 25.5 & 34.3 & & 26.3 & & & & & & 18.3 \\
\hline e. & 9.2 & 30.6 & 30.6 & 27.9 & 31.0 & 34.1 & 26.7 & 23.7 & 16.4 & 19.8 \\
\hline
\end{tabular}

FOHTES: 1) 1981-89: IAA;

2) 1989: DATAGRo (informação pessoal);

3) 1990 : DATAGRO. 
APÊHDICE 7. Consumo mensal aparente de alcool hidratado para fins carburantes. Centro-Su1, 1981-90.

$\operatorname{Mil} \mathbf{9}^{3}$

\begin{tabular}{lrrrrrrrrrrr} 
Mess & 1981 & 1982 & 1983 & 1984 & 1985 & 1986 & 1987 & 1988 & 1989 & 1990 \\
\hline Jan & 96.8 & 105.7 & 120.0 & 282.5 & 327.8 & 545.5 & 639.8 & 600.6 & 629.9 & 735.5 \\
Fev & 74.6 & 81.7 & 101.9 & 262.7 & 422.8 & 414.0 & 585.6 & 611.3 & 674.3 & 640.5 \\
Mar & 91.7 & 82.8 & 115.0 & 343.8 & 277.4 & 448.7 & 542.2 & 703.2 & 793.7 & 647.7 \\
Abr & 62.8 & 156.6 & 186.8 & 251.3 & 375.9 & 550.3 & 628.4 & 616.1 & 776.9 & 622.0 \\
Mai & 96.4 & 175.7 & 234.2 & 300.9 & 402.5 & 570.7 & 581.7 & 668.7 & 766.9 & 716.5 \\
Jun & 129.9 & 76.0 & 167.1 & 315.1 & 382.2 & 523.8 & 548.3 & 693.2 & 777.6 & 749.3 \\
Ju1 & 199.0 & 125.7 & 216.6 & 306.1 & 441.8 & 640.0 & 618.7 & 736.1 & 796.4 & 752.9 \\
Ago & 180.4 & 146.3 & 226.5 & 357.1 & 492.2 & 576.1 & 621.0 & 588.4 & 746.8 & 780.9 \\
Set & 206.6 & 138.2 & 224.8 & 270.2 & 132.1 & 610.4 & 628.9 & 668.5 & 747.0 & 688.4 \\
Out & 180.2 & 158.3 & 283.2 & 437.6 & 494.9 & 675.6 & 639.7 & 650.2 & 825.5 & 730.3 \\
Hov & 102.9 & 114.0 & 204.8 & 256.3 & 494.7 & 622.9 & 596.3 & 802.3 & 757.7 & 698.1 \\
Dez & 135.1 & 139.1 & 285.6 & 396.5 & 535.4 & 682.7 & 699.7 & 724.3 & 841.9 & 774.1 \\
\hline$-2 m-n$
\end{tabular}

FONTES: 1) 1981-88: IAA;

2) 1989: DATAGRo (informação pessoal):

3) 1990: DATAGRO. 
APÉNDICE 8. Consumo mensal aparente de álcool hidratado para fins carburantes. Horte-Hordeste, 1981-90.

\begin{tabular}{lrrrrrrrrrr} 
Mês & 1981 & 1982 & 1983 & 1984 & 1985 & 1986 & 1987 & 1988 & 1989 & 1990 \\
\hline Jan & 18.1 & 19.2 & 38.0 & 51.5 & 61.4 & 107.9 & 129.7 & 116.3 & 121.2 & 162.3 \\
Fev & 12.2 & 20.2 & 26.3 & 46.8 & 79.8 & 81.7 & 118.7 & 117.6 & 126.0 & 121.3 \\
Mar & 20.1 & 22.0 & 42.0 & 57.6 & 46.9 & 83.9 & 102.6 & 133.1 & 148.5 & 121.8 \\
Abr & 12.8 & 12.9 & 29.8 & 43.0 & 64.0 & 104.6 & 118.4 & 117.6 & 152.6 & 131.4 \\
Mai & 12.3 & 11.4 & 36.0 & 51.4 & 70.5 & 111.7 & 117.1 & 126.7 & 147.9 & 136.7 \\
Jun & - & 22.5 & 28.3 & 57.6 & 70.5 & 106.9 & 105.9 & 139.5 & 147.0 & 136.1 \\
Ju1 & - & 15.3 & 36.0 & 55.1 & 83.0 & 129.8 & 121.8 & 146.5 & 162.0 & 149.6 \\
Ago & 19.2 & 21.2 & 38.2 & 69.2 & 91.9 & 116.5 & 125.6 & 118.0 & 150.8 & 154.2 \\
Set & 35.0 & 12.8 & 39.6 & 50.0 & 25.0 & 123.5 & 125.0 & 142.0 & 148.3 & 141.8 \\
Out & 36.6 & 7.0 & 48.1 & 80.8 & 94.6 & 138.4 & 125.5 & 128.0 & 156.8 & 142.3 \\
Nov & 25.0 & 12.0 & 35.9 & 48.2 & 94.0 & 124.8 & 118.4 & 164.4 & 137.2 & 127.1 \\
Dez & 19.7 & 14.5 & 49.8 & 71.0 & 103.0 & 135.5 & 134.1 & 131.4 & 147.1 & 144.3
\end{tabular}

FOMTES: 1) 1981-88: IAA;

2) 1989: DATAGRo (informação pessoal);

3) 1990: DATAGRO. 
80.

APÊHDICE 9. Fatores de conversão para tEP médio.

tEP/m $\mathbf{m}^{3}$

\begin{tabular}{|c|c|c|c|c|}
\hline Ano & Diesel & Gasolina & Anidro & Hidratado \\
\hline 1973 & 0.836 & 0.754 & 0.520 & 0.496 \\
\hline 1974 & 0.836 & 0.754 & 0.520 & 0.496 \\
\hline 1975 & 0.836 & 0.754 & 0.520 & 0.496 \\
\hline 9976 & 0.836 & 0.741 & 0.520 & 0.496 \\
\hline 1977 & 0.836 & 0.741 & 0.520 & 0.496 \\
\hline 1978 & 0.836 & 0.741 & 0.520 & 0.496 \\
\hline 1979 & 0.836 & 0.741 & 0.520 & 0.496 \\
\hline 1980 & 0.840 & 0.749 & 0.520 & 0.496 \\
\hline 1981 & 0.840 & 0.749 & 0.520 & 0.496 \\
\hline 1982 & 0.843 & 0.750 & 0.520 & 0.496 \\
\hline 1983 & 0.841 & 0.767 & 0.520 & 0.496 \\
\hline 1984 & 0.849 & 0.766 & 0.520 & 0.496 \\
\hline 1985 & 0.845 & 0.772 & 0.520 & 0.496 \\
\hline 1986 & 0.853 & 0.772 & 0.520 & 0.496 \\
\hline 1987 & 0.851 & 0.767 & 0.520 & 0.496 \\
\hline 1988 & 0.848 & 0.773 & 0.520 & 0.496 \\
\hline 1989 & 0.848 & 0.772 & 0.520 & 0.496 \\
\hline
\end{tabular}

FOHTE: MME (1988) E MIHFRA (1990). 
B1.

APÉHDICE 10. Consumo final energético de carburantes para transportes. 10.1. Em volume. Brasil, 1973-90.

\begin{tabular}{|c|c|c|c|c|c|}
\hline \multirow{2}{*}{ Anos } & \multicolumn{4}{|c|}{$\operatorname{Mil} \mathrm{m}^{3}$} & \multirow{2}{*}{$\begin{array}{r}\text { Anidro na } \\
\text { mistura } \\
(z)\end{array}$} \\
\hline & Diesel & Hidratado & Gasolina ${ }^{\alpha}$ & Anidro & \\
\hline 1973 & 7677 & - & 13620 & 309 & 2.22 \\
\hline 1974 & 8597 & - & 14132 & 190 & 1.33 \\
\hline 1975 & 9640 & - & 14457 & 162 & 1.11 \\
\hline 1976 & 11227 & 一 & 14552 & 172 & 1.17 \\
\hline 1977 & 12079 & - & 13464 & 639 & 4.53 \\
\hline 1978 & 13334 & 2 & 13742 & 1504 & 9.86 \\
\hline 1979 & 14180 & 16 & 13426 & 2219 & 14.18 \\
\hline 1980 & 14804 & 429 & 11430 & 2253 & 16.47 \\
\hline 1981 & 14529 & 1392 & 10942 & 1146 & 9.48 \\
\hline 1982 & 14952 & 1674 & 10409 & 2021 & 16.26 \\
\hline 1983 & 14565 & 2950 & 8700 & 2197 & 20.16 \\
\hline 1984 & 14989 & 4575 & 7812 & 2082 & 21.04 \\
\hline 1985 & 15997 & 6088 & 7621 & 2121 & 21.77 \\
\hline 1986 & 17425 & 8397 & 8595 & 2442 & 22.13 \\
\hline 1987 & 18046 & 8919 & 7536 & 2136 & 22.08 \\
\hline 1988 & 18752 & 9760 & 7319 & 1966 & 21.17 \\
\hline 1989 & 19390 & 11068 & 8272 & 1622 & 16.39 \\
\hline $1990^{\circ}$ & 19399 & 10101 & 9453 & 1227 & 11.49 \\
\hline
\end{tabular}

FOHTE: MME (1988); MINFRA (1990); MIHFRA (1991).

a calculado com base en dados do Apêndice 10.2. (consumo em tEP), utilizando-se os coeficientes do Apêndice 7 referentes a 1989 . 
10.2. En taneladas equivalentes de petróleo. Brasil, 1973-90.

\begin{tabular}{|c|c|c|c|c|c|c|}
\hline \multirow{2}{*}{ Anos } & \multirow{2}{*}{ Diesel } & \multirow{2}{*}{ Hidratado } & \multirow{2}{*}{ Gasolina ${ }^{a}$} & \multirow{2}{*}{ Anidro } & \multicolumn{2}{|c|}{ Total } \\
\hline & & & & & otto & Geral \\
\hline 1973 & 6418 & - & 10269 & 161 & 10430 & 16848 \\
\hline 1974 & 7187 & - & 10656 & 99 & 10755 & 17942 \\
\hline 1975 & 8050 & - & 10900 & 84 & 10984 & 19044 \\
\hline 1976 & 9386 & - & 10783 & 89 & 10872 & 20258 \\
\hline 1977 & 10098 & - & 9977 & 333 & 10310 & 20408 \\
\hline 1978 & 11148 & 1 & 10183 & 783 & 10967 & 22115 \\
\hline 1979 & 11854 & $\mathbf{8}$ & 9948 & 1154 & 11110 & 22964 \\
\hline 1980 & 12435 & 213 & 8561 & 1172 & 9946 & 22381 \\
\hline 1981 & 12204 & 690 & 8196 & 596 & 9482 & 21686 \\
\hline 1982 & 12605 & 830 & 7807 & 1051 & 9688 & 22293 \\
\hline 1983 & 12249 & 1463 & 6673 & 1143 & 9279 & 21528 \\
\hline 1984 & 12726 & 2269 & 5984 & 1083 & 9336 & 22062 \\
\hline 1985 & 13517 & 3019 & 5883 & 1103 & 10005 & 23522 \\
\hline 1986 & 14863 & 4165 & 6635 & 1270 & 12070 & 26933 \\
\hline 1987 & 15358 & 4424 & $\mathbf{5 7 8 0}$ & 1111 & 11315 & 26673 \\
\hline 1988 & 15901 & 4841 & 5657 & 1022 & 11520 & 27421 \\
\hline 1989 & 16442 & 5490 & 6386 & 843 & 12719 & 29161 \\
\hline 1990 & 16450 & 5010 & 7298 & 638 & 12496 & 29396 \\
\hline
\end{tabular}

FOHTE: MME (1988); MIHFRA (1990); MIHFRA (1991).

a Gasolina "pura" (sem adição de anidro). 
APÊMDICE 11. Preços médios de carburantes e Produto Interno Bruto.

\begin{tabular}{|c|c|c|c|c|c|c|c|}
\hline \multirow{2}{*}{ Ano } & \multicolumn{6}{|c|}{ Cr $\$ 1000 /$ tEP } & \multirow{2}{*}{$\begin{array}{c}\text { PIB } \\
\text { (Cr\$tri) }\end{array}$} \\
\hline & Diesel & Gasolina & Hidrat & $\begin{array}{l}\text { Preço } \\
\text { Médio }\end{array}$ & $\begin{array}{r}\text { Média } \\
\text { Otto }\end{array}$ & $\begin{array}{l}\text { atto/ } \\
\text { Diesel }\end{array}$ & \\
\hline 1973 & 59.06 & 80.14 & - & 69.60 & 80.14 & 1.357 & 37.20 \\
\hline 1974 & 60.60 & 116.07 & - & 88.33 & 116.07 & 1.915 & 40.56 \\
\hline 1975 & 69.43 & 143.45 & - & 106.44 & 143.45 & 2.066 & 42.64 \\
\hline 1976 & 71.55 & 165.36 & - & 118.45 & 165.36 & 2.311 & 46.98 \\
\hline 1977 & 82.15 & 170.13 & - & 126.14 & 170.13 & 2.071 & 49.29 \\
\hline 1978 & 79.15 & 158.82 & - & 118.98 & 158.82 & 2.007 & 51.72 \\
\hline 1979 & 88.16 & 162.00 & - & 125.08 & 162.00 & 1.838 & 55.22 \\
\hline 1980 & 89.75 & 231.25 & 186.20 & 169.07 & 208.73 & 2.326 & 60.34 \\
\hline 1981 & 107.77 & 227.37 & 193.62 & 176.25 & 210.50 & 1.953 & 57.68 \\
\hline 1982 & 107.24 & 202.10 & 162.89 & 157.41 & 182.50 & 1.702 & 58.05 \\
\hline 1983 & 109.18 & 187.73 & 163.95 & 153.29 & 175.34 & 1.606 & 56.04 \\
\hline 1984 & 110.59 & 176.67 & 165.01 & 150.75 & 170.84 & $1-545$ & 58.90 \\
\hline 1985 & 96.64 & 154.05 & 148.75 & 133.15 & 151.40 & 1.567 & 63.81 \\
\hline 1986 & 71.73 & 146.46 & 142.04 & 120.07 & 144.25 & 2.011 & 68.65 \\
\hline 1987 & 64.84 & 181.26 & 181.79 & 142.63 & 181.52 & 2.800 & 71.13 \\
\hline 1988 & 60.77 & 132.32 & 139.92 & 110.00 & 136.12 & 2.240 & 71.14 \\
\hline 1989 & 43.11 & 98.76 & 113.95 & 85.27 & 106.35 & 2.467 & 73.71 \\
\hline 1990 & 44.70 & 101.23 & 116.95 & 87.63 & 109.09 & 2.441 & 70.76 \\
\hline
\end{tabular}

FOHTE: MIHFRA (1990); MINFRA (1991).

Obs.: 1) Valores originais em uss\$/bep convertidos con base nas seguintes rel ações:
a) 1 bep $=0,137$ tEP;
b) USS\$ $1.00=C_{z} \$ 39,44$ (junho de 1987);Cx\$1000 $=\mathrm{Cr} \$ 1$.
2) Valores corrigidos para dez 90 pelo IGP-DI. 
84.

APÊHDICE 12. Preços de comercialização de gasolina e álcool hidratado. Unidades monetárias correntes ${ }^{a} / 1$ itro

\begin{tabular}{|c|c|c|c|c|c|c|c|c|}
\hline \multirow{3}{*}{ Ano } & \multirow{3}{*}{ Mes } & \multicolumn{4}{|c|}{ Álcool hidratado } & \multicolumn{3}{|c|}{ Gasolina } \\
\hline & & \multicolumn{2}{|c|}{ Distribuidoras } & \multirow{2}{*}{$\begin{array}{l}\text { Postas }_{b} \\
\text { Revenda }\end{array}$} & \multirow{2}{*}{$\begin{array}{l}\text { Consu- } \\
\text { midor }\end{array}$} & \multirow{2}{*}{$\begin{array}{l}\text { Distri- } \\
\text { buidoras }\end{array}$} & \multirow{2}{*}{$\begin{array}{r}\text { Postos } \\
\text { Revenda }\end{array}$} & \multirow{2}{*}{$\begin{array}{l}\text { Consu- } \\
\text { midor }\end{array}$} \\
\hline & & C-Sul & N-HE & & & & & \\
\hline \multirow[t]{12}{*}{1981} & Jan & 21.23 & 21.46 & 23.90 & 27.50 & 44.89 & 47.80 & 51.00 \\
\hline & Fev & 25.11 & 26.72 & 23.90 & 31.52 & 50.68 & 55.48 & 59.04 \\
\hline & Mar & 25.11 & 26.72 & 28.40 & 32.00 & 51.38 & 56.40 & 60.00 \\
\hline & Abr & 25.11 & 26.72 & 28.40 & 36.67 & 51.38 & 56.40 & 62.80 \\
\hline & $\operatorname{Mai}$ & 29.44 & 31.26 & 37.80 & 42.00 & 51.38 & 56.40 & 66.00 \\
\hline & Jun & 34.69 & 36.77 & 37.80 & 42.60 & 51.38 & 56.40 & 66.90 \\
\hline & $\mathbf{J u I}$ & 34.69 & 36.77 & 43.70 & 48.00 & 59.28 & 63.78 & 75.00 \\
\hline & Ago & 34.69 & 36.77 & 43.70 & 48.00 & 66.68 & 70.70 & 75.00 \\
\hline & Set & 34.69 & 36.77 & 43.70 & 48.00 & 66.68 & 70.70 & 75.00 \\
\hline & out & 46.48 & 49.05 & 42.70 & 49.81 & 70.37 & 74.45 & 79.52 \\
\hline & Hov & 46.48 & 49.05 & 46.00 & 52.00 & 74.86 & 79.00 & 85.00 \\
\hline & Dez & 46.48 & 49.05 & 46.00 & 52.00 & 74.86 & 79.00 & 85.00 \\
\hline \multirow[t]{12}{*}{1982} & Jan & 46.48 & 49.05 & 46.00 & 52.00 & 74.86 & 79.00 & 85.00 \\
\hline & Fev & 46.48 & 49.05 & 46.00 & 58.43 & 83.60 & 89.00 & 95.18 \\
\hline & Mar & 50.09 & 52.86 & 56.13 & 64.00 & 91.17 & 97.67 & 104.00 \\
\hline & Abr & 55.80 & 58.90 & 56.13 & 64.00 & 91.17 & 97.67 & 104.00 \\
\hline & $\operatorname{Mai}$ & 55.80 & 58.90 & 56.13 & 66.61 & 96.88 & 103.08 & 110.10 \\
\hline & Jun & 55.80 & 58.90 & 64.30 & 73.00 & 110.85 & 116.30 & 125.00 \\
\hline & Ju1 & 62.08 & 65.62 & 64.30 & 74.81 & 113.36 & 119.46 & 128.16 \\
\hline & Ago & 68.77 & 72.78 & 68.30 & 77.00 & 116.41 & 123.30 & 132.00 \\
\hline & Set & 68.77 & 72.78 & 68.30 & 80.50 & 117.53 & 124.55 & 138.00 \\
\hline & out & 87.87 & 93.13 & 72.70 & 84.00 & 124.78 & 132.70 & 144.00 \\
\hline & Hov & 87.87 & 93.13 & 72.70 & 84.00 & 124.78 & 132.70 & 144.00 \\
\hline & Dez & 87.87 & 93.13 & 72.70 & 85.35 & 125.36 & 133.42 & 146.23 \\
\hline \multirow[t]{4}{*}{1983} & Jan & 87.87 & 93.13 & 86.00 & 98.00 & 142.91 & 155.00 & 167.00 \\
\hline & Fev & 87.87 & 93.13 & 86.00 & 98.00 & 142.91 & 155.00 & 167.00 \\
\hline & Mar & 108.44 & 114.93 & 86.00 & 111.77 & 170.27 & 182.96 & 190.74 \\
\hline & Abr & 108.44 & 114.93 & 107.40 & 123.00 & 181.60 & 194.40 & 210.00 \\
\hline
\end{tabular}


g5.

(cont.)APÊMDICE 12. Preços de comercializ.de gasolina e alcool hidratado. Unidades_monetárias_correntes ${ }^{a} / 1$ it

\begin{tabular}{|c|c|c|c|c|c|c|c|c|}
\hline \multirow{3}{*}{ Ano } & \multirow{3}{*}{ Mes } & \multicolumn{4}{|c|}{ Álcool hidratado } & \multicolumn{3}{|c|}{ Gasolina } \\
\hline & & \multicolumn{2}{|c|}{ Distribuidoras } & \multirow{2}{*}{$\begin{array}{l}\text { Postos } \\
\text { Revenda }\end{array}$} & \multirow{2}{*}{$\begin{array}{l}\text { Consu- } \\
\text { midor }\end{array}$} & \multirow{2}{*}{$\begin{array}{l}\text { Distri- } \\
\text { buidoras }\end{array}$} & \multirow{2}{*}{$\begin{array}{r}\text { Postos } \\
\text { Revenda }\end{array}$} & \multirow{2}{*}{$\begin{array}{l}\text { Consu- } \\
\text { midor }\end{array}$} \\
\hline & & C-Sul & H-HE & & & & & \\
\hline \multirow[t]{8}{*}{1983} & Mai & 108.44 & 114.93 & 107.40 & 123.00 & 181.60 & 194.40 & 210.00 \\
\hline & Jun & 135.18 & 143.20 & 107.40 & 163.33 & 244.72 & 260.55 & 278.20 \\
\hline & $J u 1$ & 144.91 & 153.48 & 159.60 & 178.00 & 267.67 & 284.60 & 303.00 \\
\hline & Ago & 144.91 & 153.48 & 159.60 & 192.52 & 290.83 & 308.26 & 327.19 \\
\hline & Set & 149.70 & 158.54 & 183.60 & 208.00 & 315.64 & 333.50 & 353.00 \\
\hline & out & 216.72 & 229.44 & 183.60 & 208.00 & 315.64 & 333.50 & 353.00 \\
\hline & Hov & 216.72 & 229.44 & 183.60 & 245.80 & 375.23 & 393.07 & 417.40 \\
\hline & Dez & 216.72 & 229.44 & 234.80 & 262.00 & 400.77 & 418.60 & 445.00 \\
\hline \multirow[t]{12}{*}{1984} & Jan & 216.99 & 229.86 & 234.80 & 275.55 & 423.14 & 440.99 & 468.03 \\
\hline & Fev & 241.08 & 255.39 & 302.30 & 332.00 & 516.36 & 534.30 & 564.00 \\
\hline & Mar & 318.05 & 337.56 & 302.30 & 332.00 & 516.36 & 534.30 & 564.00 \\
\hline & Abr & 318.73 & 338.63 & 302.30 & 359.73 & 554.15 & 573.08 & 610.80 \\
\hline & Mai & 318.73 & 338.63 & 347.80 & 396.00 & 603.56 & 623.80 & 672.00 \\
\hline & Jun & 464.53 & 484.47 & 347.80 & 448.20 & 661.60 & 687.19 & 737.40 \\
\hline & JuI & 464.53 & 484.47 & 515.10 & 570.00 & 797.03 & 835.10 & 890.00 \\
\hline & Ago & 470.62 & 490.53 & 515.10 & 589.35 & 823.18 & 861.87 & 919.68 \\
\hline & Set & 529.65 & 529.33 & 642.56 & 720.00 & 999.66 & 1042.56 & 1120.00 \\
\hline & Out & 716.68 & 746.52 & 642.56 & 720.00 & 999.66 & 1042.56 & 1120.00 \\
\hline & Mov & 716.68 & 746.52 & 642.56 & 856.00 & 1190.06 & 1237.54 & 1320.00 \\
\hline & Dez & 716.68 & 746.52 & 806.28 & 918 & 90 & 1330.15 & 1413.87 \\
\hline \multirow[t]{8}{*}{1985} & Jan & 716.68 & 746.52 & 1026.28 & 1110.00 & 1549.51 & 1626.28 & 1710.00 \\
\hline & Fev & 1039.39 & $1081=50$ & 1026.28 & 1120.71 & 1563.69 & 1641.06 & 1726.43 \\
\hline & Mar & 1109.55 & 1154.32 & 1280.00 & 1410.00 & 1946.54 & 2040.00 & 2170.00 \\
\hline & Abr & 1109.55 & 1154.32 & 1280.00 & 1410.00 & 1946.54 & 2040.00 & 2170.00 \\
\hline & Mai & 1109.55 & 1154.32 & 1280.00 & 1410.00 & 1946.54 & 2040.00 & 2170.00 \\
\hline & Jun & 1553.00 & 1608.10 & 1280.00 & 1410.00 & 1946.54 & 2040.00 & 2170.00 \\
\hline & Jul & 1553.00 & 1609.10 & 1280.00 & 1438.55 & 2039.83 & 2148.31 & 2286.13 \\
\hline & Ago & 1553.00 & 1608.10 & 1449.80 & 1604.52 & 2191.15 & 2323.47 & 2447.10 \\
\hline
\end{tabular}


86.

(cont.)APÉNDICE 12. Preços de comercializ.de gasolina e alcool hidratado. Unidades_monetárias correntes ${ }^{a} / 1$ itro

\begin{tabular}{|c|c|c|c|c|c|c|c|c|}
\hline \multirow{3}{*}{ Ano } & \multirow{3}{*}{ Mes } & \multicolumn{4}{|c|}{ Álcool hidratado } & \multicolumn{3}{|c|}{ Gasolina } \\
\hline & & \multicolumn{2}{|c|}{ Distribuidoras } & \multirow{2}{*}{$\begin{array}{l}\text { Postos } \\
\text { Revenda }\end{array}$} & \multirow{2}{*}{$\begin{array}{l}\text { Consu- } \\
\text { midor }\end{array}$} & \multirow{2}{*}{$\begin{array}{l}\text { Distri- } \\
\text { buidoras }\end{array}$} & \multirow{2}{*}{$\begin{array}{r}\text { Postos } \\
\text { Revenda }\end{array}$} & \multirow{2}{*}{$\begin{array}{c}\text { Consu- } \\
\text { midor }\end{array}$} \\
\hline & & C-Sul & $H-H E$ & & & & & \\
\hline \multirow[t]{4}{*}{1985} & Set & 1689.67 & 1749.62 & 1466.70 & 1739.67 & 2342.65 & 2478.54 & 2682.67 \\
\hline & Out & 2236.33 & 2315.68 & 1654.45 & 1942.25 & 2628.33 & 2774.91 & 299.65 \\
\hline & Hov & 2236.33 & $2315.6 \theta$ & 1803.40 & 2126.67 & 2891.28 & 3048.18 & 3276.67 \\
\hline & Dez & 2236.33 & 2315.68 & 2087.75 & 2387.74 & 3264.42 & 3437.45 & 3674.84 \\
\hline \multirow[t]{12}{*}{1986} & Jan & 2795.40 & 2894.58 & 2475.90 & 2740.00 & 3735.00 & 3955.90 & 4220.00 \\
\hline & Fev & 2795.40 & 2894.58 & 2475.90 & 3061.43 & 3735.00 & 3955.90 & 4711.07 \\
\hline & Mar & 2.79 & 2.89 & 2.83 & 3.10 & 3.91 & 4.14 & 4.77 \\
\hline & Abr & 2.79 & 2.89 & 2.75 & 3.10 & 4.18 & 4.42 & 4.77 \\
\hline & $\operatorname{Ma} \mathbf{i}$ & 2.79 & 2.89 & 2.75 & 3.10 & 4.18 & 4.42 & 4.77 \\
\hline & Jun & 2.79 & 2.89 & 2.75 & 3.10 & 4.18 & 4.42 & 4.77 \\
\hline & Jul & 2.79 & 2.89 & 2.83 & 3.29 & 4.48 & 4.72 & 5.07 \\
\hline & Ago & 2.79 & 2.89 & 3.61 & 3.96 & 5.51 & 5.75 & 6.10 \\
\hline & Set & 2.79 & 2.89 & 3.61 & 3.96 & 5.51 & 5.75 & 6.10 \\
\hline & Out & 2.79 & 2.89 & 3.61 & 3.96 & 5.51 & 5.75 & 6.10 \\
\hline & Hov & 3.04 & 3.15 & 3.61 & 4.76 & 6.66 & 6.93 & 7.32 \\
\hline & Dez & 3.55 & 3.67 & 6.00 & 6.35 & 8.96 & 9.27 & 9.77 \\
\hline \multirow[t]{13}{*}{1987} & Jan & 3.55 & 3.67 & 5.85 & 6.35 & 8.96 & 9.27 & 9.77 \\
\hline & Fev & 4.42 & 4.61 & 5.85 & 6.35 & 8.96 & 9.27 & 9.77 \\
\hline & Mar & 4.83 & 5.06 & 6.78 & 7.25 & 8.96 & 9.27 & 11.15 \\
\hline & Abr & 4.83 & 5.06 & 6.78 & 8. 56 & 8. 96 & 9.27 & 13.17 \\
\hline & Mai & 8. 54 & 8.93 & 8.52 & 11.86 & 15.50 & 16.09 & 18.19 \\
\hline & Jun & 10.81 & 11.30 & 11.12 & 15.60 & 21.47 & 22.15 & 23.94 \\
\hline & Jul & 11.05 & 11.54 & 15.30 & 16.80 & 23.46 & 24.30 & 25.80 \\
\hline & Ago & 11.07 & 11.56 & 15.30 & 16.80 & 23.46 & 24.30 & 25.80 \\
\hline & Set & 12.56 & 13.13 & 15.30 & 17.97 & 24.98 & 25.88 & 27.51 \\
\hline & Dut & 14.26 & 14.91 & 17.46 & 19.88 & 27.53 & 28.59 & 30.49 \\
\hline & Hov & 16.04 & 16.74 & 18.42 & 22.56 & 31.13 & 32.47 & 34.58 \\
\hline & Dez & 17.91 & 18.69 & 20.96 & 26.62 & 36.81 & 38.44 & 40.82 \\
\hline & & & & & & & & ) \\
\hline
\end{tabular}


87.

(cont.)APÉHDICE 12. Preços de comercializ.de gasolina e alcool hidratado. Unidades monetárias correntes ${ }^{a} / 1$ itro

\begin{tabular}{|c|c|c|c|c|c|c|c|c|}
\hline \multirow{3}{*}{ Ano } & \multirow{3}{*}{ Mes } & \multicolumn{4}{|c|}{ Álcool hidratado } & \multicolumn{3}{|c|}{ Gasolina } \\
\hline & & \multicolumn{2}{|c|}{ Distribuidoras } & \multirow{2}{*}{$\begin{array}{l}\text { Postos } b \\
\text { Revenda }\end{array}$} & \multirow{2}{*}{$\begin{array}{l}\text { Consu- } \\
\text { midar }\end{array}$} & \multirow{2}{*}{$\begin{array}{l}\text { Distri- } \\
\text { buidoras }\end{array}$} & \multirow{2}{*}{$\begin{array}{r}\text { Postos } \\
\text { Revenda }\end{array}$} & \multirow{2}{*}{$\begin{array}{l}\text { Consu- } \\
\text { midor }\end{array}$} \\
\hline & & C-Sul & H-NE & & & & & \\
\hline \multirow[t]{12}{*}{1988} & Jan & 19.86 & 20.74 & 24.59 & 30.02 & 41.54 & 43.46 & 46.12 \\
\hline & Fev & 23.05 & 24.07 & 28.17 & 34.59 & 47.96 & 50.14 & 53.15 \\
\hline & Mar & 26.27 & 27.42 & 32.89 & 39.29 & 54.28 & 56.68 & 60.24 \\
\hline & Abr & 29.69 & 31.00 & 38.08 & 44.46 & 61.05 & 63.77 & 68.08 \\
\hline & $\operatorname{Mai}$ & 37.96 & 39.63 & 43.73 & 53.31 & 73.22 & 76.50 & 81.80 \\
\hline & Jun & 48.77 & 50.93 & 54.78 & 65.24 & 88.52 & 92.36 & 98.48 \\
\hline & Jul & 55.65 & 58.12 & 71.03 & 78.45 & 103.00 & 107.31 & 113.68 \\
\hline & Ago & 71.55 & 74.69 & 83.78 & 127.61 & 128.06 & 133.38 & 142.13 \\
\hline & Set & 86.32 & 90.12 & 101.96 & 153.67 & 154.58 & 161.00 & 174.00 \\
\hline & Dut & 104.44 & 176.16 & 124.88 & 140.87 & 183.00 & 191.00 & 203.65 \\
\hline & Hov & 130.23 & 136.04 & 145.62 & 161.00 & 206.52 & 217.62 & 233.00 \\
\hline & Dez & 165.42 & 172.79 & 177.98 & 200.16 & 257.38 & 271.20 & 290.58 \\
\hline \multirow[t]{12}{*}{1989} & Jan & 0.23 & 0.24 & 0.22 & 0.25 & 0.35 & 0.37 & 0.40 \\
\hline & Fev & 0.25 & 0.26 & 0.29 & 0.35 & 0.38 & 0.40 & 0.43 \\
\hline & Mar & 0.25 & 0.26 & 0.29 & 0.35 & 0.38 & 0.40 & 0.43 \\
\hline & Abr & 0.25 & 0.26 & 0.29 & 0.35 & 0.38 & 0.40 & 0.43 \\
\hline & $\operatorname{Mai}$ & 0.25 & 0.25 & 0.29 & 0.39 & 0.46 & 0.48 & 0.51 \\
\hline & Jun & 0.29 & 0.29 & 0.37 & 0.44 & 0.51 & 0.55 & 0.59 \\
\hline & JuI & 0.38 & 0.38 & 0.43 & 0.59 & 0.69 & 0.74 & 0.81 \\
\hline & Ago & 0.52 & 0.54 & 0.59 & 0.79 & 0.90 & 0.97 & 1.06 \\
\hline & Set & 0.82 & 0.83 & 0.80 & 1.19 & 1.36 & 1.47 & 1.59 \\
\hline & out & 1.11 & 1.12 & 1.25 & 1.66 & 1.89 & 2.04 & 2.21 \\
\hline & Hov & 1.66 & 1.67 & 1.80 & 2.26 & 2.57 & 2.78 & 3.01 \\
\hline & Dez & 2.57 & 2.59 & 2.46 & 3.57 & 4.02 & 4.37 & 4.76 \\
\hline \multirow[t]{5}{*}{1990} & Jan & 4.25 & 4.28 & 3.96 & 6.90 & 7.40 & 8.48 & 9.20 \\
\hline & Fev & 6.65 & 6.71 & 8.15 & 11.72 & 12.17 & 14.16 & 14.98 \\
\hline & Mar & 13.39 & 13.52 & 12.73 & 22.70 & 23.78 & 27.86 & 30.22 \\
\hline & Abr & 15.18 & 15.32 & 24.62 & 22.70 & 28.79 & 33.82 & 36.90 \\
\hline & & & & & & & \multicolumn{2}{|c|}{ (continua) } \\
\hline
\end{tabular}


88.

(cont.)APÊHDICE 12. Preços de comercializ.de gasolina e alcool hidratado. Unidades monetárias correntes ${ }^{a} / 1$ itro

\begin{tabular}{|c|c|c|c|c|c|c|c|c|}
\hline \multirow{3}{*}{ Ano } & \multirow{3}{*}{ Mes } & \multicolumn{4}{|c|}{ Alcool hidratado } & \multicolumn{3}{|c|}{ Gasolina } \\
\hline & & \multicolumn{2}{|c|}{ Distribuidoras } & \multirow{2}{*}{$\begin{array}{l}\text { Postos } \\
\text { Revenda }\end{array}$} & \multirow{2}{*}{$\begin{array}{l}\text { Consu- } \\
\text { midor }\end{array}$} & \multirow{2}{*}{$\begin{array}{l}\text { Distri- } \\
\text { buidoras }\end{array}$} & \multirow{2}{*}{$\begin{array}{r}\text { Postos } \\
\text { Revenda }\end{array}$} & \multirow{2}{*}{$\begin{array}{c}\text { Consu- } \\
\text { midor }\end{array}$} \\
\hline & & C-sul & H-WE & & & & & \\
\hline \multirow[t]{8}{*}{1990} & $\operatorname{Mai}$ & 15.18 & 15.32 & 24.62 & 22.70 & 28.79 & 33.82 & 36.90 \\
\hline & Jun & 15.18 & 15.32 & 24.62 & 22.70 & 28.79 & 33.82 & 36.90 \\
\hline & Jul & 15.18 & 15.32 & 24.62 & 22.70 & 28.79 & 33.82 & 36.90 \\
\hline & Ago & 18.53 & 18.61 & 24.62 & 31.27 & 34.19 & 38.56 & 41.64 \\
\hline & Set & 22.09 & 22.29 & 26.71 & 29.11 & 38.94 & 43.68 & 38.75 \\
\hline & Dut & 25.54 & 25.77 & 31.92 & 33.24 & 44.72 & 50.05 & 44.24 \\
\hline & Nov & 32.80 & 39.50 & 38.56 & 42.32 & 57.58 & 64.01 & 56.33 \\
\hline & Dez & 37.00 & 46.38 & 49.52 & 47.80 & 65.19 & 72.36 & 63.63 \\
\hline
\end{tabular}

FOHTE: PETROBRÁs (19991, informação pessoal); Diário Oficial da Uniäo.

a Até 27/02/86: Cr\$; a partir de 28/02/86: Cz\$; a partir de 16/01/89: HC2\$; a partir de 16/03/90: Cr\$.

b Preços no inicio do mes, produto a $20 \circ \mathrm{C}$. 
APÊMDICE 13. Custos de comercialização do ál cool carburante.

Eq_valores correntes a

\begin{tabular}{|c|c|c|c|c|c|c|}
\hline \multirow{2}{*}{ Ano } & \multirow{2}{*}{ Mês } & \multicolumn{2}{|c|}{ Transporte } & \multirow{2}{*}{ Armazen } & \multirow{2}{*}{ Perdas } & \multirow{2}{*}{ Total } \\
\hline & & PETROBRAS & Distrib & & & \\
\hline \multirow[t]{12}{*}{1983} & Jan & 915.3 & - & 60.3 & 113.6 & 1089.2 \\
\hline & Fev & 607.7 & - & 21.4 & 72.0 & 701.1 \\
\hline & Mar & 591.1 & - & 36.3 & 97.1 & 724.5 \\
\hline & Abr & 261.6 & - & 30.1 & 59.1 & 350.8 \\
\hline & $\operatorname{Mai}$ & 355.3 & - & 56.0 & 87.1 & 498.4 \\
\hline & Jun & 371.3 & - & 61.2 & 130.2 & 562.7 \\
\hline & Ju1 & 728.5 & - & 141.1 & 187.9 & 1057.5 \\
\hline & Ago & 1171.4 & - & 182.3 & 224.3 & 1578.0 \\
\hline & Set & 1255.0 & - & 187.5 & 258.7 & 1701.2 \\
\hline & Dut & 1755.6 & - & 207.2 & 315.2 & 2278.0 \\
\hline & Hov & 1539.2 & - & 131.6 & 399.4 & 2070.2 \\
\hline & Dez & 1707.4 & - & 181.6 & 379.4 & 2268.4 \\
\hline \multirow[t]{12}{*}{1984} & Jan & 6271.7 & - & 557.6 & 435.2 & 7264.5 \\
\hline & Fev & 3019.0 & $\longrightarrow$ & 264.7 & 435.9 & 3719.6 \\
\hline & Mar & 2820.9 & - & 249.4 & 476.3 & 3456.6 \\
\hline & Abr & 5215.4 & - & 215.0 & 598.6 & 6029.0 \\
\hline & $\operatorname{Mai}$ & 5177.9 & - & 91.3 & 590.5 & 5859.7 \\
\hline & Jun & 6365.3 & - & 800.6 & 746.3 & 7912.2 \\
\hline & Jul & 5826.7 & - & 1619.9 & 963.6 & 8410.2 \\
\hline & Ago & 5055.6 & - & 765.7 & 1386.4 & 7207.7 \\
\hline & Set & 3237.3 & - & 544.8 & 1474.2 & 5256.3 \\
\hline & Out & 5775.2 & - & 528.9 & 2172.8 & 8476.9 \\
\hline & Hov & 33344.0 & - & 4758.7 & 1767.7 & 39870.4 \\
\hline & Dez & 13960.3 & - & 1294.1 & 1970.3 & 17224.7 \\
\hline \multirow[t]{6}{*}{1985} & Jan & 8.1 & -60.7 & 1.2 & 0.9 & -50.5 \\
\hline & Fev & 14.4 & 87.3 & 2.4 & 1.8 & 105.9 \\
\hline & Mar & 10.7 & 28.0 & 1.6 & 1.9 & 42.2 \\
\hline & Abr & 25.6 & 15.6 & 4.1 & 7.6 & 52.9 \\
\hline & $\operatorname{Mai}$ & 12.9 & 18.3 & 2.2 & 8.5 & 41.9 \\
\hline & & & & & & intinua) \\
\hline
\end{tabular}


(cont.) APÊHDICE 13. Custos de comercialização do álcool carburante.

Em valores correntes ${ }^{a}$

\begin{tabular}{|c|c|c|c|c|c|c|}
\hline \multirow{2}{*}{ Ano } & \multirow{2}{*}{ Mês } & \multicolumn{2}{|c|}{ Transporte } & \multirow{2}{*}{ Armazen } & \multirow{2}{*}{ Perdas } & \multirow{2}{*}{ Total } \\
\hline & & PETROBRAS & Distrib & & & \\
\hline \multirow[t]{7}{*}{1985} & Jun & 16.5 & 184.7 & 3.1 & 3.1 & 207.4 \\
\hline & Jul & 31.2 & 194.7 & 4.0 & 3.8 & 233.7 \\
\hline & Ago & 37.4 & 161.5 & 5.6 & 4.2 & 208.7 \\
\hline & Set & 40.9 & 202.5 & 7.8 & -13.6 & 237.6 \\
\hline & Dut & 48.5 & 565.2 & 7.4 & 5.1 & 626.2 \\
\hline & Hov & 34.7 & 474.4 & 3.5 & 5.2 & 517.8 \\
\hline & Dez & 54.4 & 402.9 & 4.3 & 4.2 & 465.8 \\
\hline \multirow[t]{12}{*}{1986} & Jan & 59.6 & 406.3 & 3.0 & 5.3 & 474.2 \\
\hline & Fev & 56.3 & 267.6 & 10.4 & 5.3 & 339.6 \\
\hline & Mar & 63.5 & 312.8 & 9.5 & 5.6 & 391.4 \\
\hline & Abr & 43.4 & 276.4 & B.8 & 5.5 & 334.1 \\
\hline & Mai & 45.5 & 265.6 & 7.8 & 6.3 & 325.2 \\
\hline & Jun & 75.8 & 312.4 & 8.5 & 5.5 & 402.2 \\
\hline & Jul & 64.9 & 285.4 & 11.5 & 6.1 & 367.9 \\
\hline & Ago & 54.0 & 294.4 & 10.2 & 6.3 & 364.9 \\
\hline & Set & 98.7 & 315.5 & 9.9 & 6.9 & 431.0 \\
\hline & Out & 103.8 & 286.0 & 9.5 & 7.3 & 406.6 \\
\hline & Mov & 79.2 & 295.5 & 7.5 & 7.5 & 389.7 \\
\hline & Dez & 96.1 & $-437-1$ & 12.6 & 9.5 & -318.9 \\
\hline \multirow[t]{9}{*}{1987} & Jan & 68.6 & -334.0 & 12.7 & 9.9 & -243.5 \\
\hline & Fev & 59.3 & 432.5 & 7.9 & 8.3 & 508.0 \\
\hline & Mar & 120.8 & 162.1 & 15.4 & 11.8 & 310.1 \\
\hline & Abr & 126.3 & -76.6 & 15.2 & 10.3 & 75.2 \\
\hline & Mai & 165.3 & 729.9 & 21.6 & 20.1 & 936.9 \\
\hline & Jun & 278.2 & 1202.0 & 30.8 & 31.1 & 1542.1 \\
\hline & Ju1 & 282.5 & 873 . 1 & 19.7 & 22.1 & 1197.4 \\
\hline & Ago & 305.1 & 785.8 & 19.0 & 17.8 & 1127.7 \\
\hline & Set & 371.8 & 1222.5 & 39.6 & 26.0 & $\begin{array}{r}1659.9 \\
\text { (tinua) }\end{array}$ \\
\hline
\end{tabular}


(cont.) APÉNDICE 13. Custos de comercialização do alcool carburante.

\begin{tabular}{|c|c|c|c|c|c|c|}
\hline \multirow{2}{*}{ Ano } & \multirow{2}{*}{ Mês } & \multicolumn{2}{|c|}{ Transporte } & \multirow{2}{*}{ Arrazen } & \multirow{2}{*}{ Perdas } & \multirow{2}{*}{ Total } \\
\hline & & PETROBRAS & Distrib & & & \\
\hline \multirow[t]{3}{*}{1987} & out & 398.3 & 1746.6 & 64.6 & 23.5 & 2233.0 \\
\hline & Hov & 347.6 & 928.0 & 67.3 & 32.5 & 1375.4 \\
\hline & Dez & 387.7 & 1465.6 & 69.8 & 30.5 & 1953.6 \\
\hline \multirow[t]{12}{*}{3988} & Jan & 418.9 & 1557.8 & 79.7 & 39.6 & 2096.0 \\
\hline & Fev & 563.1 & 1722.9 & 68.2 & 51.9 & 2406.1 \\
\hline & Mar & 630.4 & 1582.1 & 113.8 & 55.2 & 2381.5 \\
\hline & Abr & 760.5 & 2219.8 & 119.4 & 58.3 & 3158.0 \\
\hline & $\operatorname{Mai}$ & 727.5 & 2000.0 & 138.4 & 88.4 & 2954.3 \\
\hline & Jun & 1319.6 & 7786.9 & 180.1 & 84.9 & 9371.5 \\
\hline & $\mathbf{J u} 1$ & 1349.2 & 8160.1 & 198.0 & 70.9 & 9724.2 \\
\hline & Ago & 1484.6 & 8253.3 & 204.3 & 132.1 & 10074.3 \\
\hline & Set & 1980.6 & 10250.2 & 313.0 & 158.6 & 12702.4 \\
\hline & Out & 2556.0 & 10694.2 & 333.4 & 355.5 & 13939.1 \\
\hline & Hov & 3755.2 & 4011.7 & 372.3 & 244.3 & 8383.5 \\
\hline & Dez & 4856.3 & 5409.7 & 449.5 & 272.9 & 10988.4 \\
\hline \multirow[t]{12}{*}{1989} & Jan & 4409.9 & 1548.6 & 5187.9 & 428.6 & 11575.0 \\
\hline & Fev & 6526.6 & -3721.9 & 544.2 & 478.6 & 3827.5 \\
\hline & Mar & 8744.4 & -4388.4 & 993.0 & 511.5 & 5890.5 \\
\hline & Abr & 8873.2 & -4255.0 & 914.4 & 444.9 & 6007.5 \\
\hline & $\operatorname{Mai}$ & 9032.8 & 2904.9 & 857.7 & 388.4 & 13183.8 \\
\hline & Jun & 5860.8 & 1010.5 & -3622.4 & 476.6 & 3725.5 \\
\hline & Jul & 9626.7 & -4610.4 & 687.9 & 441.4 & 6145.6 \\
\hline & Ago & 17300.9 & 47541.9 & 1297.4 & 889.6 & 67029.8 \\
\hline & Set & 19815.2 & 40631.7 & 1762.8 & 1378.6 & 63588.3 \\
\hline & Dut & 25384.4 & 55329.0 & 2917.3 & 2036.7 & 85667.4 \\
\hline & Hov & 37076.3 & 156832.9 & 2552.0 & 2808.0 & 199269.2 \\
\hline & Dez & 58460.2 & 329393.3 & 5295.6 & 4199.5 & 397348.6 \\
\hline \multirow[t]{2}{*}{1990} & Jan & 71709.5 & 327519.6 & 399229.1 & 5139.6 & 414315.2 \\
\hline & Fev & 194428.0 & -43207.9 & 13201.1 & 8882.1 & $\begin{array}{r}173303.3 \\
\text { (continua) }\end{array}$ \\
\hline
\end{tabular}


(cont.) APÊHDICE 13. Custos de comercializaçãa do alcool carburante.

Em valores correntes ${ }^{a}$

\begin{tabular}{rrrrrrr}
\hline Ano Mês & \multicolumn{2}{c}{ Transporte } & & & \\
& & PETROBRAS & Distrib & Armazen & Perdas & Total \\
\hline 1990 & Mar & 162788.9 & -1008.9 & 26720.3 & 14949.2 & 203449.5 \\
& Abr & 298850.1 & -613409.9 & 29147.0 & 16666.3 & -268746.5 \\
Mai & 293956.8 & -1337793.4 & 23108.0 & 19346.0 & -1001382.6 \\
Jun & 465500.1 & -1153768.9 & 26171.5 & 24522.4 & -637574.9 \\
Jul & 592215.0 & -973847.0 & 27209.0 & 27000.0 & -327423.0 \\
Ago & 474255.0 & 46194.0 & 33767.0 & 27393.0 & 581609.0 \\
Set & 423424.0 & 2790738.0 & 40114.0 & 25325.0 & 3279601.0 \\
Out & 504754.0 & 1470574.0 & 40341.0 & 37777.0 & 2053446.0 \\
Hov & 633850.0 & 2565475.0 & 68986.0 & 57432.0 & 3325743.0 \\
Dex & 726218.0 & 1952079.0 & 89483.0 & 58570.0 & 2826350.0 \\
\hline
\end{tabular}

FONTE: PETROBRÁs (1991, informação pessaal).

a 1983-84: Cz\$ mil; 1985-88: Cz\$ milhöes; 1989-90: Cr\$ mil. 
93.

APÊHDICE 14. Frota e consumo médio de veículos a álcool.

\begin{tabular}{|c|c|c|c|c|}
\hline Ano & $\begin{array}{c}\text { Veiculos a al- } \\
\text { cool no merc. } \\
\text { interno } \\
\text { (unidades) }\end{array}$ & $\begin{array}{l}\text { Frota estimada } \\
\text { (unidades) }\end{array}$ & $\begin{array}{c}\text { Consumo de } \\
\text { alcool } \\
\text { hidratado } \\
\left(10^{9} \mathrm{~m}^{3}\right)\end{array}$ & $\begin{array}{c}\text { Consumo } \\
\text { médio } \\
\text { anual } \\
\text { (mºic) }\end{array}$ \\
\hline 1981 & 137.307 & 369.765 & $1.767,4$ & 4,78 \\
\hline 1982 & 233.497 & 553.810 & $1.691,1$ & 3,05 \\
\hline 1983 & 581.373 & 966.415 & $2.814,5$ & 2,91 \\
\hline 1984 & 568.163 & 1.517 .847 & $4.462,3$ & 2,94 \\
\hline 1985 & 647.445 & 2.083 .617 & $5.654,3$ & 2,71 \\
\hline 1986 & 698.564 & 2.759 .476 & B.225, 9 & 2,98 \\
\hline 1987 & 459.238 & 3.250 .977 & $8.773,1$ & 2,70 \\
\hline 1988 & 565.699 & 3.693 .083 & $9.644,0$ & 2,61 \\
\hline 1989 & 405.302 & 4.110 .735 & $10.880,0$ & 2,65 \\
\hline 1990 & 81.998 & 4.220 .390 & $10.205,1$ & 2,42 \\
\hline
\end{tabular}

FOHTE: DATAGRO (1991); Apêndices 7 e 8. 
APÊMDICE 15. Valores médios anuais; álcool anidro carburante, 1981-90.

(Cr\$/litro, valores de dez.90)

\begin{tabular}{lrrrrrrrrr} 
Ano & Parid & Subtot Faturae & Subsid & Funrur & Distrib & Postos & Consun \\
\hline 1981 & 79.94 & 89.46 & 90.14 & 7.42 & 1.08 & 153.89 & 165.20 & 177.28 \\
1982 & 77.29 & 86.77 & 87.67 & 6.06 & 1.12 & 136.04 & 144.31 & 155.71 \\
1983 & 68.80 & 77.50 & 78.48 & 5.27 & 0.94 & 127.07 & 135.40 & 144.42 \\
1984 & 66.54 & 75.03 & 75.98 & 4.04 & 0.86 & 122.43 & 127.58 & 135.84 \\
1985 & 68.29 & 76.66 & 77.63 & 3.42 & 0.84 & 109.18 & 114.85 & 122.33 \\
1986 & 53.61 & 60.15 & 60.83 & 2.54 & 0.89 & 100.26 & 105.12 & 113.15 \\
1987 & 56.63 & 63.38 & 64.21 & 2.40 & 0.91 & 121.67 & 126.16 & 138.85 \\
1988 & 50.19 & 56.05 & 56.80 & 1.94 & 0.79 & 99.31 & 103.80 & 110.71 \\
1989 & 42.05 & 49.78 & 49.77 & 1.58 & 1.06 & 66.87 & 71.27 & 71.27 \\
1990 & 37.97 & 43.03 & 47.59 & 1.22 & 0.64 & 64.40 & 73.65 & 73.65
\end{tabular}

FOHTE: Apêndices 2, 3, 5, 6 e 12 .

Obs.: Valores corrigidos pelo IGP-DI. 
APÊHDICE 16. Valores médios anuais; alcool hidratado carburante, 1981-90. (Cr\$/1itro, valores de dez.90)

Ano Parid Subtot Faturan Subsid Funrur Distrib Postos Consum

\begin{tabular}{lllllllll}
1981 & 75.48 & 82.78 & 84.86 & 4.58 & 1.00 & 84.99 & 94.36 & 107.12 \\
1982 & 73.36 & 80.79 & 83.06 & 4.13 & 1.05 & 83.07 & 79.79 & 92.66 \\
1983 & 64.30 & 70.64 & 73.45 & 4.63 & 0.89 & 73.38 & 71.26 & 84.54 \\
1984 & 63.07 & 69.57 & 72.17 & 3.70 & 0.83 & 72.22 & 73.08 & 84.37 \\
1985 & 64.93 & 71.43 & 73.71 & 3.20 & 0.82 & 73.96 & 70.22 & 78.69 \\
1986 & 50.52 & 55.52 & 57.50 & 2.47 & 0.86 & 57.50 & 65.50 & 74.18 \\
1987 & 53.65 & 58.48 & 60.96 & 2.41 & 0.85 & 60.71 & 76.55 & 90.42 \\
1988 & 47.38 & 51.82 & 53.86 & 2.11 & 0.77 & 54.10 & 63.36 & 77.50 \\
1989 & 39.20 & 43.02 & 46.74 & 1.71 & 0.66 & 40.70 & 44.86 & 57.73 \\
1990 & 35.34 & 39.22 & 44.31 & 1.31 & 0.62 & 36.12 & 47.27 & 55.53 \\
\hline
\end{tabular}

FOHTE: Apêndices $2,4,7,8$ e 12.

abs.: Valores corrigidos pelo IGP-DI. 
APÊHDICE 17. Relações entre elementos de receita e elementos de despesa do Governo e o preço da gasolina ao consumidor final.

\begin{tabular}{|c|c|c|c|c|c|c|c|c|c|c|c|}
\hline \multirow{2}{*}{ no } & \multicolumn{6}{|c|}{ Anidro } & \multicolumn{5}{|c|}{ Hidratado } \\
\hline & $a_{1}$ & $a_{2}$ & $b_{1}$ & $b_{2}$ & $\mathbf{b}_{\mathbf{g}}$ & & $h_{1}$ & $h_{2}$ & $g_{1}$ & $g_{2}$ & $-\Sigma g$ \\
\hline 781 & 0.868 & 0.088 & 0.508 & 0.042 & 009 & 0 & 479 & 073 & 9 & 26 & 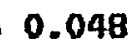 \\
\hline 982 & 0.874 & 0.098 & 0.563 & 0.039 & 0.010 & 60 & 533 & 0.083 & 0.533 & 0.027 & 056 \\
\hline 983 & 0.880 & 0.098 & 0.543 & 0.036 & 0.010 & 0.388 & 0.512 & 0.083 & 0.509 & 32 & 255 \\
\hline 984 & 0.901 & 0.100 & 0.559 & 0.030 & 0.010 & 0.402 & 532 & 0.088 & 0.531 & 27 & 061 \\
\hline 985 & 0.893 & 0.108 & 0.635 & 0.028 & 0.011 & & 0.605 & 0.094 & 0.603 & 26 & 070 \\
\hline 986 & 0.886 & 0.096 & 0.538 & 0.022 & 0.009 & 0.412 & 0.508 & 0.085 & 0.508 & 0.022 & 0.063 \\
\hline 987 & 0.876 & 0.085 & 0.462 & 0.017 & 0.008 & 0.473 & 0.437 & 0.074 & 0.439 & 0.017 & 055 \\
\hline 88 & 0.897 & 0.091 & 0.513 & 0.018 & 0.009 & & 0.489 & 0.081 & 0.486 & 0.019 & 0.064 \\
\hline 989 & 0.869 & 0.177 & 0.647 & 0.021 & 0.011 & 0.368 & 0.529 & 0.107 & 0.607 & 0.022 & 0.006 \\
\hline 0 & 0.869 & 0.202 & 0.642 & 0.016 & 0.010 & 0.403 & 0.488 & 0.129 & 0.598 & 0.018 & 0.001 \\
\hline
\end{tabular}

FoHTE: Apêndices 15 e 16.

0b5.: $a_{1}$ : preço as distribuidoras; $a_{2}$ : tributos; $b_{1}$ : preço aos produtores; $b_{2}$ : subsidio de equalização de custos; $b_{3}$ = encargos de mistura do anidro a gasolina; $h_{1}$ : preço as distribuidoras; $h_{2}$ : tributos; $g_{1}=$ preço aos produtores; $g_{2}=$ subsidio de equalização de custos. 
APÊHDICE 18. Estigativa do saldo do Governo (1981-90).

Valores de dez 90

\begin{tabular}{|c|c|c|c|c|c|c|c|}
\hline Ano & $\begin{array}{r}\text { Consumo } \\
\text { Anidro } \\
\left(\text { (mil }{ }^{3}\right)\end{array}$ & $\Sigma a-\Sigma b$ & $\begin{array}{l}\text { Consumo } \\
\text { Hidratado } \\
\left.\text { (mil } \operatorname{s}^{3}\right)\end{array}$ & $\sum \mathbf{h}-\Sigma \mathbf{g}$ & $\begin{array}{c}\text { Preço } \\
\text { Gasolina } \\
(\text { Cr } \$ / 1)\end{array}$ & $\begin{array}{l}\text { Transp. } \\
\text { Armazen. } \\
\text { (Crs bi) }\end{array}$ & $\begin{array}{r}\text { Saldo } \\
\text { Governo } \\
\text { (Crs bi) }\end{array}$ \\
\hline & CA & A & $\mathrm{CH}$ & H & PG & CTE & S6 \\
\hline 1981 & 1146.1 & 0.397 & 1767.4 & 0.048 & 177.28 & *t* & 95.70 \\
\hline 982 & 2020.9 & 0.360 & 1691.1 & 0.056 & 155.71 & $4 *$ & 128.03 \\
\hline 1983 & 2196.5 & 0.388 & 2814.5 & 0.055 & 144.42 & 7.21 & 138.23 \\
\hline 1984 & 2081.6 & 0.402 & 4462.3 & 0.061 & 135.84 & 17.70 & 132.95 \\
\hline 1985 & 2120.9 & 0.326 & 5654.3 & 0.070 & 122.33 & 108.68 & 24.32 \\
\hline 786 & 2442.4 & 0.412 & 8225.9 & 0.063 & 113.15 & 80.06 & 92.44 \\
\hline 87 & 2135.8 & 0.473 & 8773.1 & 0.055 & 138.85 & 61.84 & 145.43 \\
\hline 88 & 1988.5 & 0.448 & 9644.0 & 0.064 & 170.71 & 75.65 & 181.79 \\
\hline 89 & 1723.8 & 0.368 & 10880.0 & 0.006 & 76.97 & 29.82 & 24.03 \\
\hline 990 & 1300.5 & 0.403 & 10205.1 & 0.001 & 74.08 & 15.76 & 23.82 \\
\hline
\end{tabular}

FOHTE: Apendices $5,6,7,8,13,15$ e 16.

* Dados nãa disponiveis.

Obs.: SG = (A.CA + H.CH) PG - CTE [U. eq. (14)]. 
98.

APÊNDICE 19. Projeção dos saldos do Governo na comercialização de alcool carburante. Cenario otimista, 1991-95.

\begin{tabular}{|c|c|c|c|c|c|c|}
\hline \multirow[t]{2}{*}{ Ano } & \multirow{2}{*}{$\begin{array}{c}\text { Demanda } \\
\text { total } \\
10^{\circ} \text { tEP }\end{array}$} & \multirow{2}{*}{$\begin{array}{l}\text { Demanda } \\
\text { diesel/ } \\
\text { otto }\end{array}$} & $\begin{array}{c}\text { Demanda } \\
\text { ot to }\end{array}$ & \multirow{2}{*}{$\begin{array}{c}\text { Consumo } \\
\text { hidratado } \\
10^{\circ} \mathrm{m}^{3}\end{array}$} & \multirow{2}{*}{$\begin{array}{l}\text { Consumo } \\
\text { anidro } \\
10^{6} \cdot \mathrm{m}^{9}\end{array}$} & \multirow{2}{*}{$\begin{array}{r}\text { Saldo do } \\
\text { Governo } \\
\text { Cr\$ } 10^{\circ}\end{array}$} \\
\hline & & & $10^{\circ}$ tEP & & & \\
\hline 1991 & 29,64 & 1,321 & 12,77 & 9,69 & 1,40 & 66,83 \\
\hline 1992 & 29,47 & 1,332 & 12,64 & 8,31 & 1,22 & 113,96 \\
\hline 1993 & 29,39 & 1,348 & 12,52 & 7,50 & 2,18 & 244,22 \\
\hline 1994 & 29,82 & 1,363 & 12,62 & 6,77 & 2,30 & 300,50 \\
\hline 1995 & 30,65 & 1,376 & 12,90 & 6,11 & 2,45 & 336,30 \\
\hline
\end{tabular}

FOWTE: Tabulações do autor.

Obs.: Valores en Cr\$ corrigidos para dez.90 pelo IGP-DI. 
APÊHDICE 20. Projeção dos saldos do Governo na comercialização de álcool carburante. Cenário intermediário, 1991-95.

\begin{tabular}{lcccccc} 
Ano & $\begin{array}{c}\text { Demanda } \\
\text { total } \\
10^{6} \text { tEP }\end{array}$ & $\begin{array}{c}\text { Demanda } \\
\text { diesel/ } \\
\text { otto }\end{array}$ & $\begin{array}{c}\text { Demanda } \\
\text { otto } \\
10^{6} \text { tEP }\end{array}$ & $\begin{array}{c}\text { Consumo } \\
\text { hidratado }\end{array}$ & $\begin{array}{c}\text { Consumo } \\
\text { anidro }\end{array}$ & $\begin{array}{r}\text { Saldo do } \\
\text { Governo }\end{array}$ \\
\hline 1991 & 29,55 & 1,317 & 12,75 & 10,20 & 1,10 & 20,64 \\
1992 & 29,50 & 1,318 & 12,73 & 10,20 & 1,26 & 30,94 \\
1993 & 29,67 & 1,319 & 12,79 & 10,20 & 1,44 & 44,56 \\
1994 & 30,07 & 1,319 & 12,97 & 10,20 & 1,48 & 49,70 \\
1995 & 30,65 & 1,320 & 13,21 & 10,20 & 1,52 & 55,20 \\
\hline
\end{tabular}

FOHTE: Tabulações do autor.

Obs.: Valores en Cr\$ corrigidos para dez.90 pelo IGP-DI. 
APÊhDICE 21. Projeção dos saldos do Governo na comercialização de álcool carburante. Cenário pessimista, 1991-95.

\begin{tabular}{lcccccr} 
Ano & $\begin{array}{c}\text { Demanda } \\
\text { total } \\
10^{\circ} \text { tEP }\end{array}$ & $\begin{array}{c}\text { Demanda } \\
\text { diesel } \\
\text { otto }\end{array}$ & $\begin{array}{c}\text { Demanda } \\
\text { otto } \\
10^{\circ} \text { tEP }\end{array}$ & $\begin{array}{c}\text { Consumo } \\
\text { hidratado } \\
10^{\circ} \mathrm{m}^{3}\end{array}$ & $\begin{array}{c}\text { Consumo } \\
\text { anidro } \\
10^{\circ} \mathrm{m}^{3}\end{array}$ & $\begin{array}{r}\text { Saldo do } \\
\text { Governo }\end{array}$ \\
\hline 1991 & 28,92 & 1,316 & 12,49 & 11,25 & 0,84 & $10^{\circ}$ \\
1992 & 28,87 & 1,315 & 12,47 & 12,40 & 0,77 & $-1,57$ \\
1993 & 28,93 & 1,313 & 12,51 & 13,67 & 0,82 & $-51,64$ \\
1994 & 29,05 & 1,309 & 12,58 & 15,08 & 0,73 & $-107,54$ \\
1995 & 29,28 & 1,305 & 12,70 & 16,62 & 0,54 & $-163,44$ \\
\hline
\end{tabular}

FOHTE: Tabulaçöes do autor.

Obs.: Valores em Cr\$ corrigidos para dez.90 pelo IGP-DI. 